\title{
Upstream Water Piracy, the Strongest Weapon of Cornering a Downstream Nation
}

\author{
Miah Muhammad Adel \\ Interdisciplinary Sciences Research Center, Department of Chemistry \& Physics, University of Arkansas at Pine Bluff, 1200 North \\ University Drive, Pine Bluff, AR 71601, P. O. Box 4941 \\ *Corresponding Author: adelm@uapb.edu
}

Copyright $@ 2013$ Horizon Research Publishing All rights reserved.

\begin{abstract}
The article reviews about 100 meetings between India and her counterparts Pakistan and Bangladesh, and the Bangladesh's consenting, for her least survivability to avoid the worst Indian cornering by the unilateral water piracy, to India's right to the Ganges water piracy by the Farakka Barrage over the Ganges to establish the No. 1 waterway across India. Sources of information have been published articles and news in electronic and print media, site visitations, experts' interviews, field work, travel accounts, research institutions and government offices. The Bangladesh's courteous consent to a 41-day test-run of the barrage in April 1975 ended in Indian unilateral piracy that continued until 1977 when a 5-year consent to piracy was signed after raising the issue to the UN General Assembly that prompted Indian dailies heinous comments against Bangladesh. Later, in two memoranda of understanding the piracy right was granted in 1982 and 1985. Unilateral water piracy continued 1988 through 1996 toward the end of which the consent to a 30-year piracy right was signed. Indian water piracy by other dams and barrages upstream of the Farakka is on the rise causing the ever-decreasing Ganges discharge through Bangladesh that has resulted in the world's worst ecocide. The UN should consider water pirates committing multiple crimes of ecosystem water deprivation, drinking water poisoning, climate change, and global environmental change, and subject them to international sanction, and look for downstream ecosystem damages of any degree by the upstream water management in the criminal investigation.
\end{abstract}

Keywords Ganges basin, Farake Barrage, water piracy, Bangladesh, India, piracy right, memoranda of understanding, test-run, ecosystem, human rights

\section{Introduction}

\subsection{Water Piracy and Water Piracy Right}

India and Bangladesh have 58 common international rivers. The major ones are the Ganges, the Brahmaputra, the Surma-Meghna, the Teesta, and the Atrai. These are shown in Figs. 1 and 2. About $50 \%$ of the international rivers have one or more constructions at the upstream for water piracy which has been defined as the upstream withdrawals of water from the downstream ecosystem harming it to any degree. The upstream country can compel the downstream country which, for her least survivability and out of fear of being cornered through unilateral water piracy, consent to the upstream country's conditions of water division. In south Asia, India has set up an instance in which she being the upstream riparian country locked her own water in reservoirs to create a fake water shortage in the Hooghly river system to pirate downstream Bangladesh's ecosystem's water from the unconnected Ganges river system. Also, in other common rivers, she set up dams, regulators, groyens, etc. to deprive the downstream Bangladesh of her due share. The downstream country Bangladesh is cornered to the extent of ecocide in the Ganges basin if no consent is given to water piracy. In other river basins, she pirates water unilaterally without paying attention to Bangladesh's repeated complaints. India never gives serious consideration Bangladesh's water rights. The Indian-built constructions at the upstream for piracy in the Indo-Bangladesh common rivers are marked in red Fig. 2. In the scenario of the forced water withdrawals without recognizing the downstream water rights, "piracy" in lieu of "diversion" or "withdrawal" and words like "right to piracy" or "piracy right" have been thought to be the most wisely chosen and the most appropriate terms with the least sensitivity for using in this article.

\subsection{The Downstream Dilapidated Ecosystem in Bangladesh}

An ecosystem cannot survive with just about $40 \%$ of its founding and sustaining water requirements. Due to the piracy of the elixir water, many elements of the biotic system have been extinct and the rest are endangered. The ecocide effects in the Ganges basin include the loss of the surface 
water resources, destruction of the inland navigable routes, the depletion of the natural breeding and raising grounds of 109 species of Gangetic fishes and the natural wells for groundwater recharge, the alarmingly sinking of the groundwater table and its contamination with arsenic in the continued absence of the recharging surface water and the over-dependence on the groundwater, the sufferings of 75 million people from the risk of arsenicosis causing a $20 \%$ fatality, the break-off of family ties of arsenic patients, rising malnutrition among the people from the scarcity of fish, the cheapest sources of calcium and the indispensable animal protein, the loss of people's annual and seasonal livelihoods, the generation of extreme climate with an increased number of warmer summer days and colder winter days than before the beginning of the piracy in 1975 , scanty and erratic rainfalls, the loss of numerous biodiversity before the preparation of an inventory, coastal erosion, widespread inland advancement of saline water front, and the deterioration of the Ganges water quality (Miah, 1995, 1996a, 1996b, 1996c, 1996d; Miah and Samad, 1996; Miah, 1997; Adel, 1999a, 1999b, 2000a, 2000b, 2001, 2002, 2003, 2004a, 2004b, 2005, 2008a, 2008b, 2012a, 2012b, 2013a, 2013b, 2013c, 2013d, 2013e)

\subsection{The Ganges and the Hooghly - Two Separate River Systems}

The Ganges and the Hooghly have been two separate river systems for, at least, several hundred years beyond the establishment of the Calcutta Port at the mouth of the Hooghly River. A seasonal canal called the Hooghly canal linked the Ganges and the Hooghly. The downstream Gangetic ecosystem in Bangladesh was founded and maintained by the Ganges discharge through Bangladesh. The downstream Ganges which is also known as the Padma flows through Bangladesh to fall into the Bay of Bengal after meeting with the Brahmaputra and then with the Meghna. The Padma has only one tributary in Bangladesh known as the Mahananda that faces two dams in its upstream in Bangladesh (left hand top corner in Fig. 3).

The Hooghly is a very tributary-rich river system (Fig. 4). Following the setup of the Damodar Valley Corporation (DVC) in the 1950s, Indian government constructed a number of dams and reservoirs on the tributaries of the Hugli/Bhagirathi. These are the Ajoy, the Mayurakshi, the Panchet Reservoir, the Maithon Reservoir, the Tilaiya Reservoir, the Konar Reservoir, the Subarnarekha Multipurpose, and the Kangsabati, numbered 18 through 24 under major irrigation projects under West Bengal rivers in
Fig. 1 in the left side near the bottom

\subsection{India's Creation of Fake Water Shortage in the Hooghly}

The tributaries and the sub-tributaries of the Hooghly lost their capacity to flush the Hugli because of being dammed. India had a simultaneous plan to construct the Farakka Barrage (Fig. 5) $16 \mathrm{~km}$ upstream from the international border on the Ganges to pirate water flowing through Bangladesh to establish the nation's No. 1 waterway across her as shown in Fig. 6. The construction of reservoirs in the upstream of the Hooghly's tributaries and sub-tributaries to lock the incoming water to the Hooghly to create a water shortage in the Hooghly was a trick India used to raise a huge hue and cry to justify the piracy right of the Bangladesh Ganges basin ecosystem's water (Adel, 2013a, $2013 \mathrm{~b}, 2013 \mathrm{~d}$ ). India made the false case of maintaining the navigability of the Calcutta Port located downstream about $510 \mathrm{~km}$ away, which could be easily solved if the locked water in the Hooghly's reservoirs was released.

The artificially-made navigability loss of the Calcutta port, $126 \mathrm{~km}$ above the sea, was not of such a critical issue that necessitated deprivation of the Bangladesh Ganges basin ecosystem's elixir water, because three and one-half decades later than the construction of the Farakka Barrage, India estimated the dredging and maintenance cost of the Calcutta port (October 25, 2011 Business Line). However, the declaration of the Ganga-Bhagirathi-Hooghly river route from Allahabad to Haldia as the National Waterway No.1 was made at a much earlier date - just a decade after the construction of Farakka (vide National Waterway, Allahabad-Haldia stretch of the Ganga Bhagirathi- Hooghly River, Act 1982 (49 of 1982). The waterways started operation from 27th Oct 1986 after the formation of the IWAI. It stretches out from Haldia to Allahabad for a distance of $1620 \mathrm{kms}$ as shown in Fig. 6 (http://india-wris.nrsc.gov.in/wrpinfo/index.php?title=Natio nal_Waterways-1).

The minimum depths available in this post-Farakka developed and Bangladesh ecosystem's water-fed route is 3 $\mathrm{m}$ for Haldia-Farakka, $2.5 \mathrm{~m}$ for Farakka - Patna, $2 \mathrm{~m}$ for Patna-Varanasi, and $1.5 \mathrm{~m}$ for Varanasi-Allahabad. The expanse of the newly developed perennially navigable route is Haldia (Sagar)-Farakka)- $560 \mathrm{~km}$, Farakka-Patna- $460 \mathrm{~km}$, and Patna-Allahabad-600 km making a total of 1,620 km. Other than piracy, India steals water from the border rivers as shown in Fig. 7. 


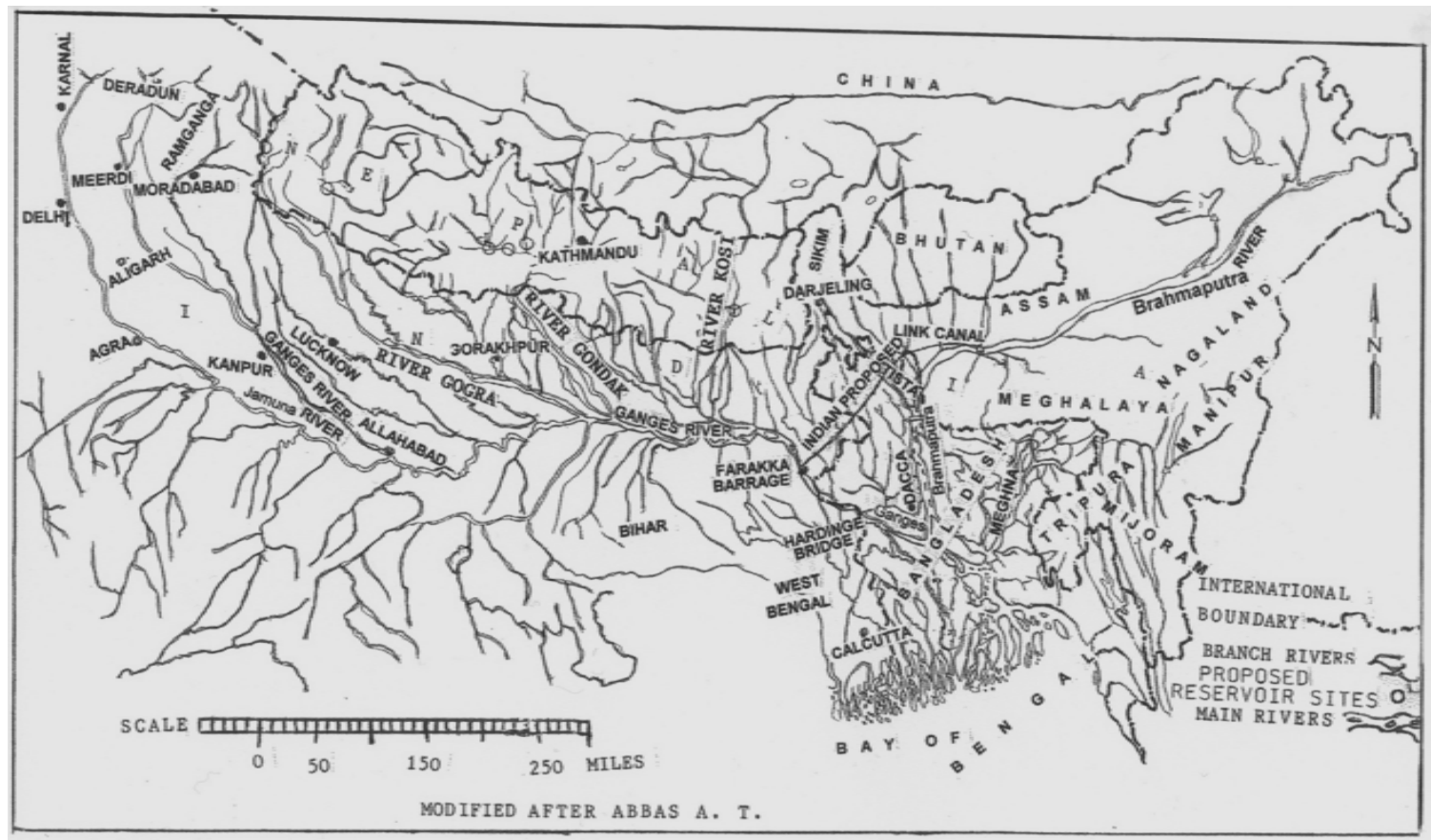

Figure 1. Indian proposed link canal. It shows the tributaries of the Ganges including the Gandak (following B. M. Abbas )

Up until June 1995, seventy seven meetings were held between the two countries - prime ministerial and the topmost level 4, ministerial level 17, Joint River Commission Advisory level 13, ministerial level 21, ministerial level of joint expert committees 2, secretarial level 10 , secretarial level on tranboundary river water sharing 6, secretarial level of joint expert committees 2 and foreign ministers' level 2 . There were ten more meetings -5 expertise level and 5 secretarial level - held between India and Pakistan on the Farakka issue during the Pakistan period (1952-70). All together there were 87 meetings between the downstream and upstream parties. These meetings were held in Pakistan's capitol Islamabad, Bangladesh's capitol Dhaka, India's capitol New Delhi, two provincial capitol of India Calcutta and Bangalore, Nepal's capitol Kathmandu, Bahama's capitol Nasaw, and in the United Nations Office in New York.

\subsection{Marathon Number of Futile Meetings and Water Piracy}

Until the signing a 30-year water piracy right for India on 12 December 1996, one 41-day test-run agreement in 1975, one 5-year water piracy treaty in 1977, two memoranda of water piracy understanding in 1982 and 1988 were signed between the two countries. India took advantages of longer-term unilateral water piracy for a total of about ten years by the Farakka Barrage in between shorter-term piracy rights. Shorter or relatively longer piracy consent is obtained from Bangladesh for availing a longer term unilateral piracy right when the consented terms expire. Occasional short-term water piracy consents ensure the succeeding ones less favorable for the downstream country than the preceding ones because of the absence of arbitration and gradually decreasing discharges at the Farakka point as the construction of dams and barrages upstream of the Ganges continued (Figs. 8 and 9).

\subsection{World's Riparian Countries' Basins Development}

Instances of cooperative agreements on river flow sharing and river basin development exist in the same or interconnected river basins among the riparian nations across the world. In 1954, six nations participated in the Mekong River Treaty based on fair distribution of water. Syria and Lebanon reached an agreement on sharing the water of the Orontes River. Mexico and the United States signed the treaty on sharing the Rio Grande and the Colorado River flows in 1944. France fulfilled Spain's demands. In 1970, the settlement of the dispute over Vardar/Axois river between Macedonia (a republic of former Yugoslavia) and North Greece was done under the auspices and technical and financial assistance from the United Nations. It may be mentioned that the river basin area is $23,747 \mathrm{sq} \mathrm{km}$ of which 91\% lies in Macedonia and 9\% in Greek Macedonia (Goodman, 1997). However, there has not been any instances of creating fake water shortages in one river system by locking the water in reservoirs and then pirating the downstream ecosystem's water from a different river system to make up for the artificially-created shortage. And to avail this upper hand gain, no upstream country has cornered any downstream country. India's hegemony over small neighbors is out of sheer disrespect for them. 


\subsection{The Focus of this Article}

The article focuses on the fruitless marathon meetings toward India's receiving the water piracy rights, from time to time, from the downstream ecosystem, following which the world's worst ecocide effects have evolved in Bangladesh. The schedules of the meetings shed light on Indian hegemony over a tiny neighbor, a national attitude that in this era of globalization warrants full exploration with all the resources available. The entire schedules of meetings which represent a unique series of events have been depicted because of historical reasons and have been duly placed in the section on results and discussions. Each new piracy right has gone more against the downstream country harming her more and more. Without consenting to India-mandated terms and conditions, the water shortage plights of Bangladesh knows no bounds. Also, it reflects the Indian authority over international river control which is driven more by politics than by the importance of saving ecosystems in the age of saving the diversity.

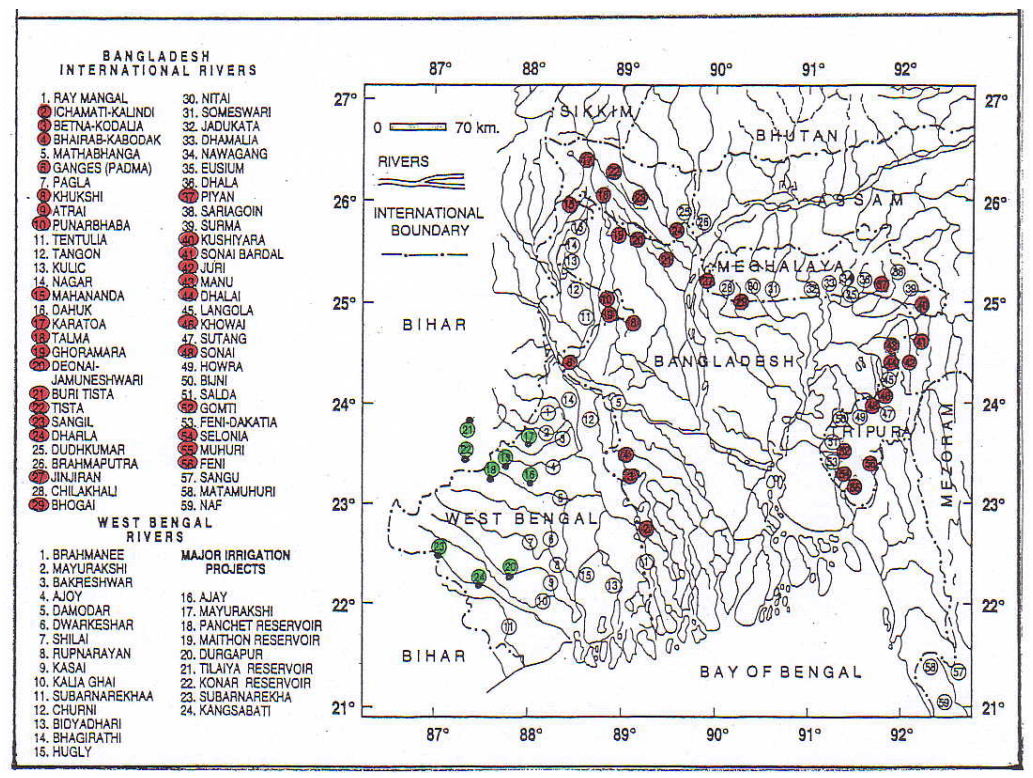

Figure 2. The ring of dams and barrages around the Bangladesh border, a unique technique of subjugating little neighbors

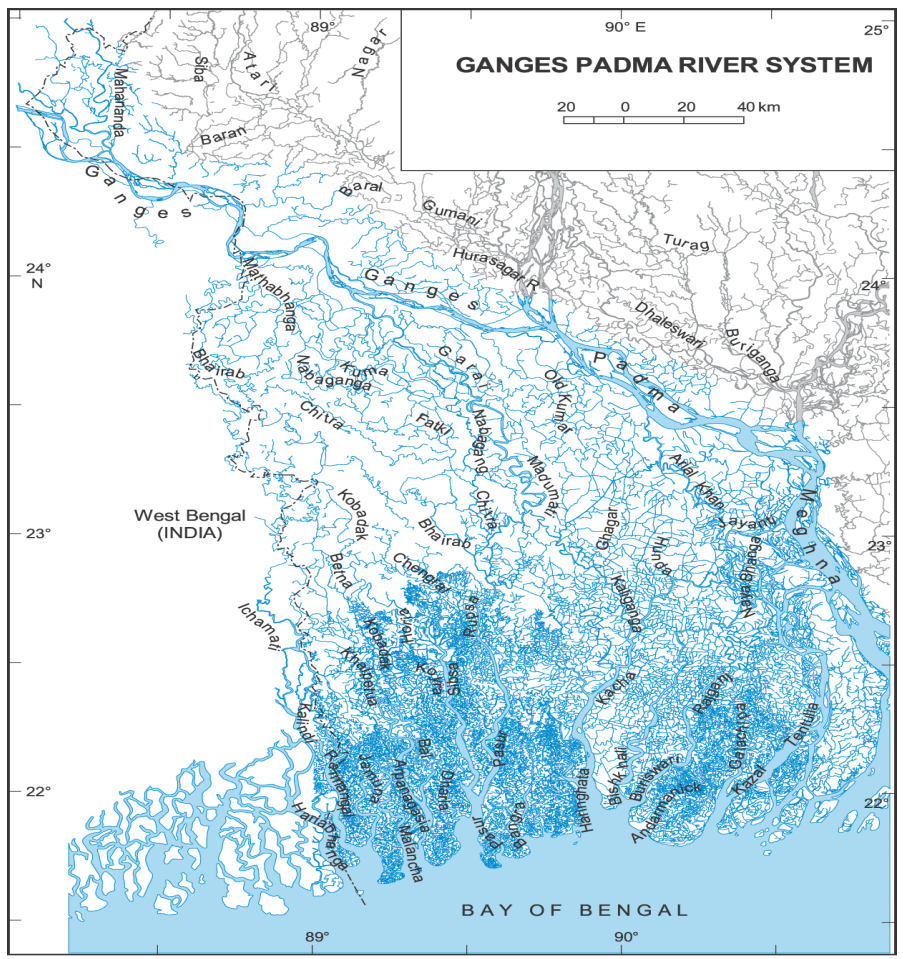

Figure 3. The downstram Ganges basin in Bangladesh. The Mahananda River is located at the left side top corner of the Ganges basin. (http?www.banglapedia.org/httpdocs/maps/mg_0027.gif) 


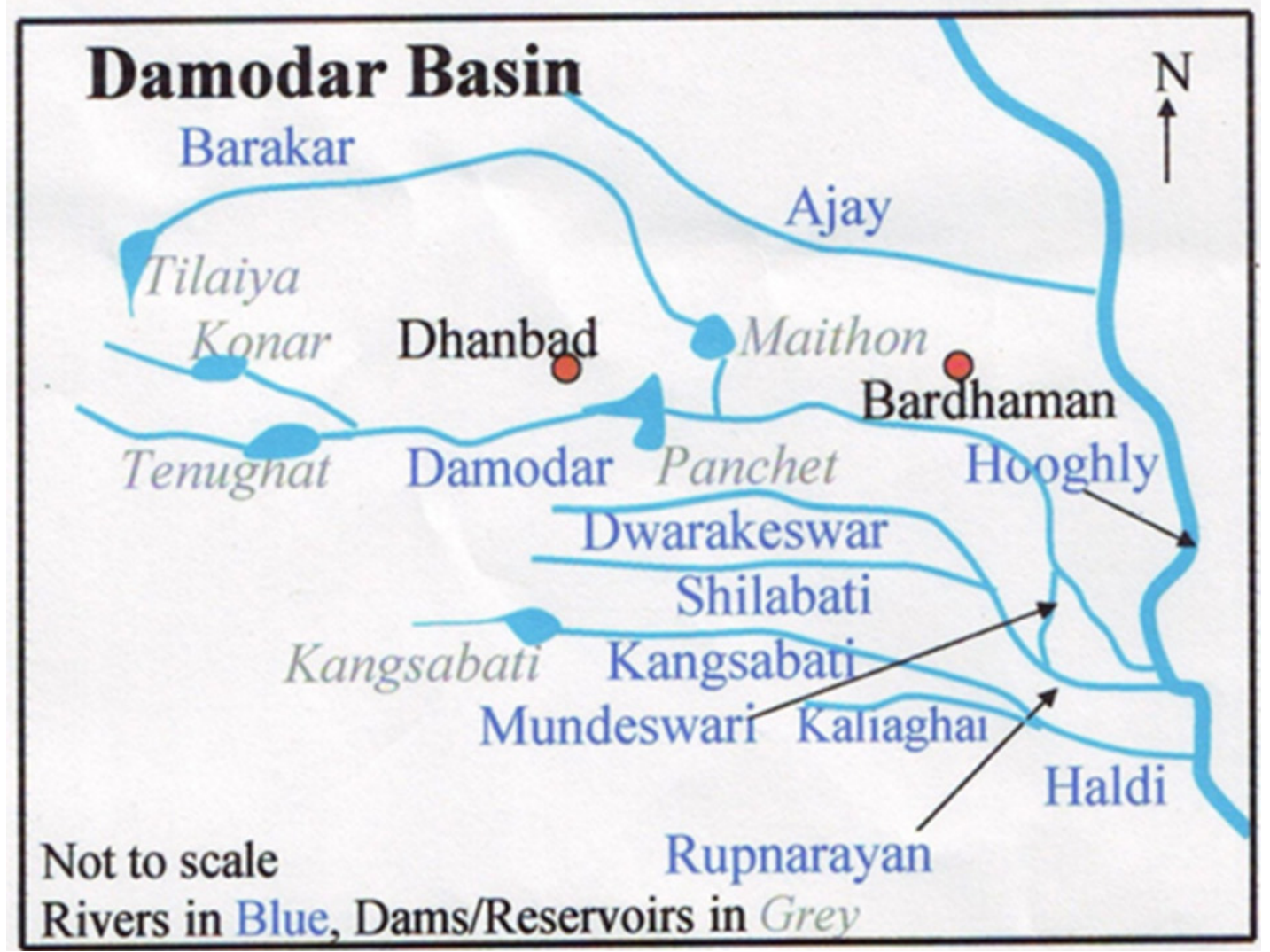

Figure 4. The tributary-rich Hooghly basin. . (http://en.wikipedia.org/wiki/Damodar_River

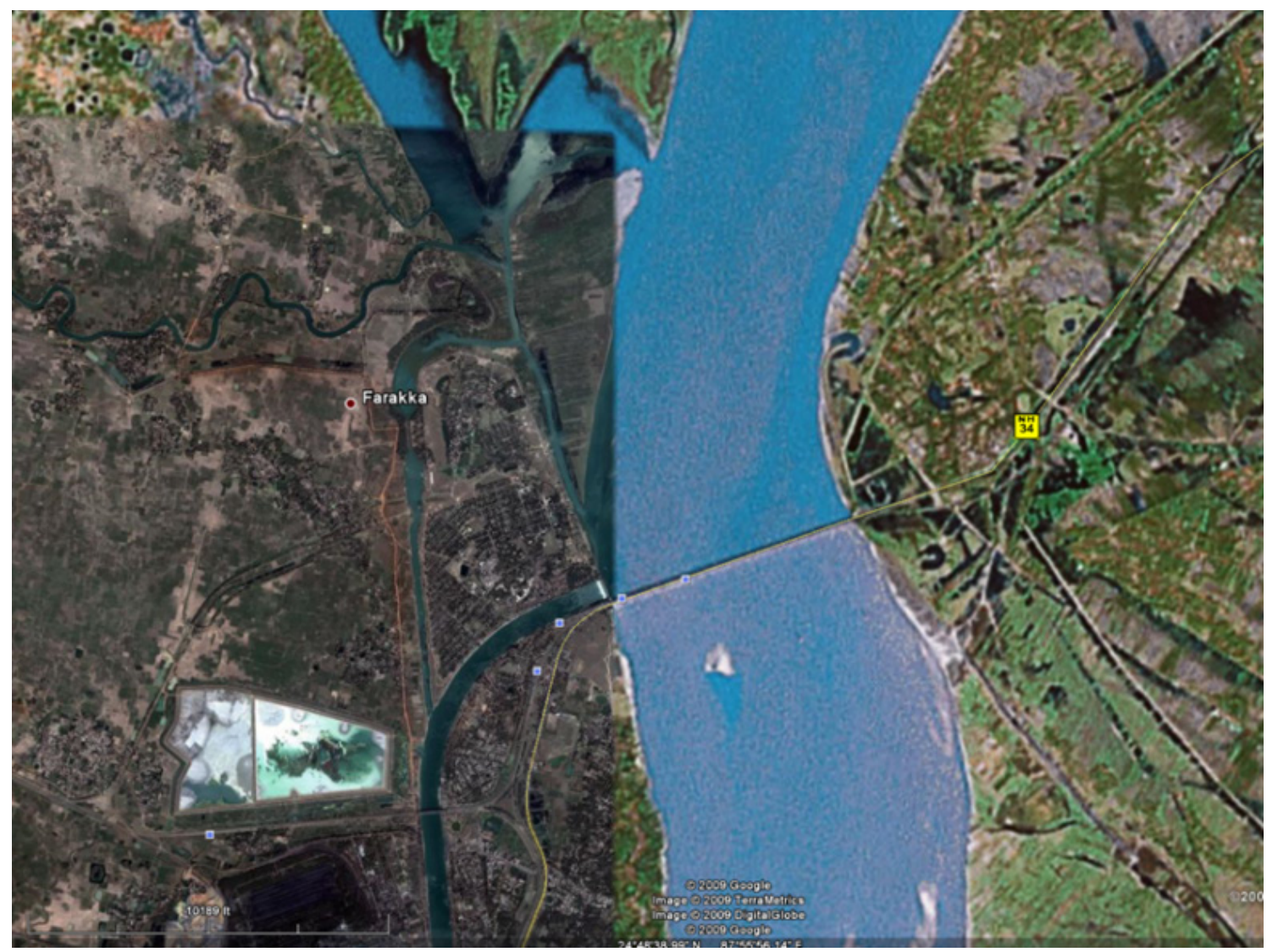

Figure 5. Farakka Barrage over the Ganges and the excavated perennially navigable $25-\mathrm{km}$ long feeder canal on left side to connect to the Hooghly for establishing the nation's No. 1 waterways. (Courtesy of Google) 


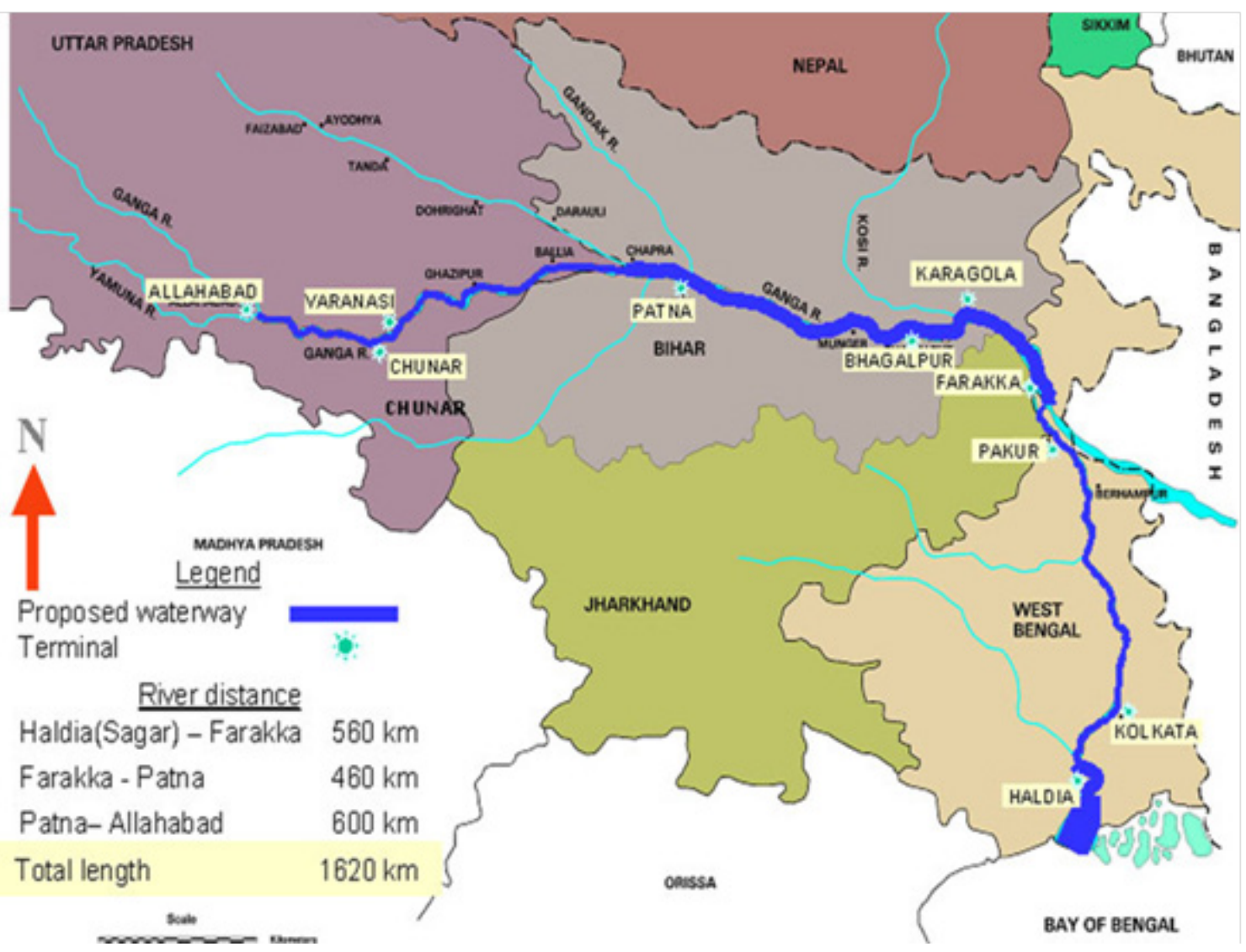

Figure 6. Ganga-Bhagirathi-Hooghly river system from Allahabad to Haldia was declared as National Waterway No.1 (1 $\underline{\text { http://india-wris.nrsc.gov.in/wrpinfo/index.php?title=National_Waterways-1) }}$

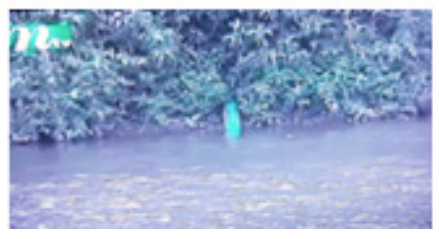

(a)
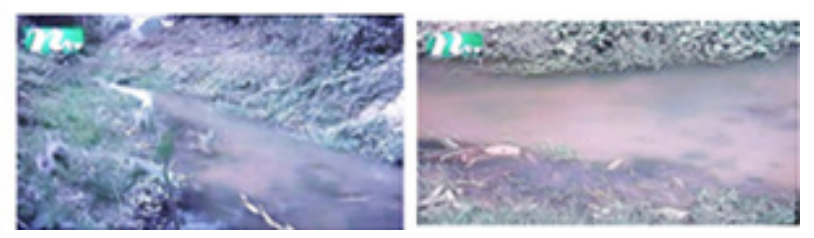

(b)

Figure 7. One instance of India's water stealing using pipes through the jungle or underground from the Bangladesh's Feni River, (b) canals carrying water to distant farm lands lack adequate water for irrigation (Courtesy of ntv, an international TV channel from Bangladesh).

\section{Materials and Methods}

This article is based on the reviews of relevant materials dating back to the independence of India from the British rule in the middle of the last century. India's huge hue and cry was centered on the navigability loss of the Hooghly River and Calcutta Port which necessitated looking back at the data of all constructions in the basins of the tributaries and sub-tributaries of the Hooghly and Calcutta Port's rise in undivided India and fall in the post-independence India. Search results revealed India's procrastination in the long series of meetings after meetings with a view to keep the issue hanging, a side-strategy to corner Bangladesh. Further, searches were made as to how the Hooghly lost its navigability and if India turned her attention to the development of the ports. Additionally, thorough searches were made to find India's ultimate plan of using the pirated water. Sources of data had been site visitation, field work, interviews, travel accounts, books, thesis, newspaper articles, news items, maps, government offices, research institutions, and websites. 


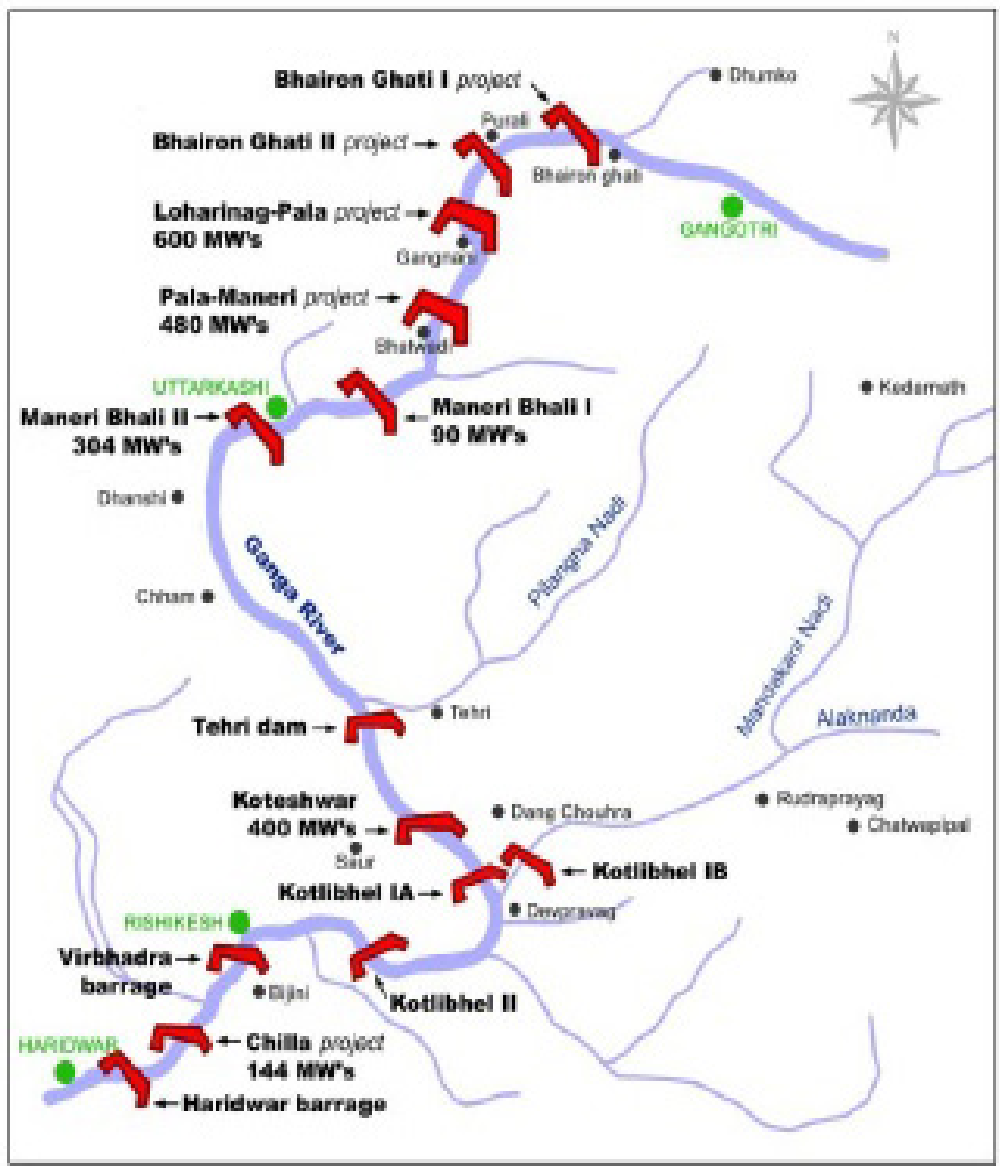

Figure 8. Operational, underconstruction, and proposed barrages on the Ganges (http://www.slideshare.net/Manushilndia/ganga-held-captive)

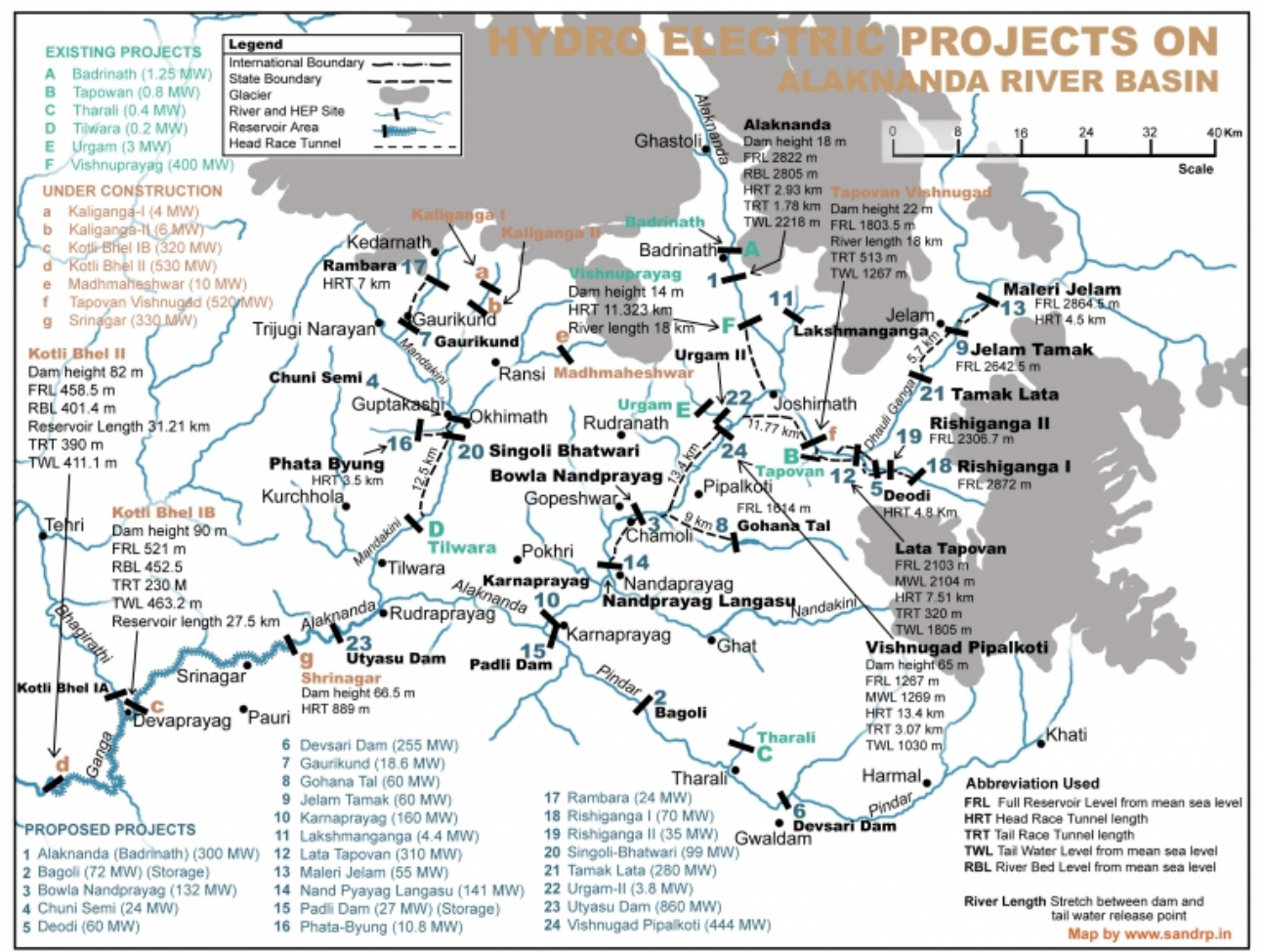

Figure 9. Planned, underconstruction, and operational dams in the Alakand River, a tributary of the Ganges shown (coming from the right) in Fig. 8http://www.bing.com/images/search?q=Alakand+River+Map\&id=F54943AE3A3A0A0EA6041C806E77F7E116956FA\&FORM=IQFRBA\# 


\section{Results}

Historic meetings held between the two parties, although worked at the background to set up the evolved scenarios mentioned later, has been put in this section because of the reviews of these historic meetings form one of the objectives of this article and were discovered in the search of the literature.

\subsection{India's Farakka Barrage Plan and Procrastinating Responses to Pakistan's Concerns (1952-70)}

In October 1951, Indian dailies published the news that India would build the Farrakka Barrage to divert water to the Hooghly River. Pakistan protested to India's decision on 29 October 1951. On 8 March 1952, a period of 4 months later, India informed Pakistan that she would be informed of the plan before its materialization. In the meantime, India took the project of pirating water from the Gandok River (Fig. 1), a tributary of the Ganges originating in Nepal, to Bihar and Uttar Pradesh. The withdrawal of water from the Gandok affects the flow of the Ganges. On 8 May 1952, Pakistan informed India of the losses East Pakistan would face if water was diverted. More than a year later on 22 May 1953, India informed Pakistan that Farakka and Gandak projects were under investigation. Indian side had always been slow to respond to her counterpart to get her job done.

On 14 September 1954, Pakistan informed India of her (Pakistan's) Ganga-Kabodak Irrigation project in downstream East Pakistan. Correspondences were exchanged between the two nations for long nine years. The two nations started sharing information of their respective projects in 1960. However, India shared only on the Farakka project. She refused to share what other projects she was working on the upstream of Farakka.

On 28 June 1960, Pakistan and India met for the first time at the expert level in Delhi, India. The second meeting was held on 1 October 1960 in Dhaka. Pakistan's President wrote to Indian Prime Minister on 27 March 1961. Indian Premier wrote back on 29 April agreeing to share information. But it was never done. On 28 April 1961, the two parties met in Calcutta for the third time which followed by Indian Government's formation of Farakka Barrage Control Board and Technical Advisory Committee. On 27 December 1961, the two parties met in Dhaka for the fourth time. Long six years' later in 1967, Indian counterpart refused Pakistan's proposal to meet at the expert level led by Pakistan's High Commissioner to India. After long seven years, their $5^{\text {th }}$ meeting was held on 13 May 1968 in New Delhi. Indian Government was buying time to complete the construction of the Farakka Barrage.

In the Secretarial level, the two parties met on 9 December 1968 for ten days in New Delhi, on 21 May 1969 for five days in Islamabad, on 15 July 1969 for twelve days in New Delhi, on 24 February 1970 for eight days in Islamabad, and finally on 16 July 1970 for six days in New Delhi. There was little success in the last meeting. The key issue of water sharing remained unsolved. In the meantime, India finished the construction of the Farakka Barrage. What remained to be done was the construction of the feeder canal (Sattar, 1996, 1998).

Table 1 and table 2 in the Appendix, record the historic communications and meetings, respectively, between India and Pakistan. In 20 years - 1951 through 1971 - nothing was done on the water issue except the exchange of information and refuting of Indian reasons.

Table 1. Indo-Pakistan Correspondences

$\begin{array}{cc}\text { Pakistan's Letter } & \text { Indian Response } \\ 29 \text { October } 1951 \text { protest } & 8 \text { March } 1952 \\ 8 \text { May } 1952 & 22 \text { May } 1953 \\ \text { 14 September } 1954 & ?\end{array}$

Table 2. Indo-Pakistan Meetings

$\begin{array}{lll}\text { \# Level of Meeting } & \text { Place } & \text { Duration } \\ \text { 1st Expert } & \text { New Delhi } & \text { 28 June - 3 July } 1960 \\ \text { 2nd Expert } & \text { Dhaka } & \text { 1-3 October } 1960 \\ \text { 3rd Expert } & \text { Calcutta } & \text { 28-30 April 1961 } \\ \text { 4th Expert } & \text { Dhaka } & \text { 27 Dec - 8 Jan. } 1962 \\ \text { 5th Expert } & \text { New Delhi } & \text { 13 -26 May 1968 } \\ \text { 6th Secretary } & \text { New Delhi } & \text { 9-19 December } 1968 \\ \text { 7th Secretary } & \text { Islamabad } & \text { 21-25 May 1969 } \\ \text { 8th Secretary } & \text { New Delhi } & \text { 15-26 July 1969 } \\ \text { 9th Secretary } & \text { Islamabad } & \text { 24 Feb.-2 March '70 } \\ \text { 10th Secretary } & \text { New Delhi } & \text { 16-21 July 1970 }\end{array}$

\subsection{India's Waits to Hit the Jackpot}

Unrest started in Pakistan in 1971 that took the shape of civil war when India came as a friend to East Pakistan in her war of independence against Pakistan. Some people firmly believe that it was Indian intelligence service RAW that helped to break Pakistan. This was the opportunity India had been waiting for establishing a remotely-controlled neo-colonialism in would-be Bangladesh to serve Indian interests contrary to which the small country Bangladesh would be cornered on many issues. Indian policy is now working. Bangladesh emerged as an independent state but under the Indian grip as has been evidenced from Indian actions.

\subsection{Marathon Meetings during Bangladesh Period (1971 -1996)}

Searching the relevant documents have revealed the chronology of the marathon numbered meetings that should not had taken place but did take place as the upstream stuck to her undue demands and the downstream did not find any alternative for her survival.

\subsection{Formation of the Joint River Commission (JRC)}

Indian Premier came to visit Bangladesh on 17 March, 1972. Bangladesh raised a proposal for the formation of a joint river commission (JRC). During 26 - 29 April, 1972, the irrigation ministers of the two countries held discussion 
in Dhaka on the proposed river commission. The objective was to maintain regular correspondences for receiving maximum benefits from the international rivers common to both the nations, to carry out jointly research projects on flood control, implementation of flood control projects, and out other responsibilities asked by the governments of the countries. It was decided for the commission to meet annually four times. However, the Bangladesh's counterpart has never paid due importance to this inter-governmental organization as reflected in the delayed responses and postponement of scheduled meetings.

The joint River Commission met for the first time during 25-26 June 1972 in New Delhi. The Commission discussed the water problems of the common rivers leaving aside the issue of the Ganges, the supplier of elixir to one-third of the Bangladesh's ecosystem. Ministers of the two countries met on 16-17 July 1973 to hold discussion on the water issue. Later, on 15 February 1974, the foreign ministers of the two countries met in Dhaka to discuss the same issue.

\subsubsection{India's Absurd Proposal}

During 12-16 May 1974, premiers of the two countries met in Delhi and issued a joint communiqué stating that the Farakka Barrage will be operating by the end of 1974. The Ganges flow during the dry months is not enough to meet the demands of the two countries. To meet that demand, the Ganges flow has to be increased during the dry season. What the Indian Premier tried to mean was to set up a link canal between the Brahmaputra and the Ganges and to divert the Brahmaputra water upstream of the Ganges, a point that became clear in the follow-up $8^{\text {th }}$ meeting of the JRC in 20 days in Dhaka. Indian side referred to its Prime Minister's proposal of the link canal to divert $2,830 \mathrm{cu} \mathrm{m} / \mathrm{s}$ of water from the Brahmaputra to the Ganges. The 337-km long (Figs. 1 and 10) canal would originate in Assam, India, would enter northern Bangladesh at an elevation of $31 \mathrm{~m}$, then rise to an elevation of $40 \mathrm{~m}$ at the mid-section before dropping down. To raise water at the higher elevation at the mid-section, India proposed to build a barrage at Jogighopa in Assam, indicated in Fig. 1 by "Indian Proposal" linking the Brahmaputra coning from the north-east with the Ganges coming from the north-west.

There would be many pitfalls associated with this proposal.
Firstly, a large portion of the canal would be embanked, which would obstruct the natural drainage of the land causing water logging during rainy season. Secondly, the proposed canal would cross as many as fourteen rivers including the three major rivers of the Teesta, the Korotoa, and the Atrai (Fig. 10). The design of the three major intersections or cross-overs would present engineering challenge and would be very expensive. Thirdly, the proposed canal would use up to $121 \mathrm{sq} \mathrm{km}$ of invaluable land in the land-scarce country and

displace over a million poor people. Fourthly, the construction of the Jogighopa Barrage in Assam would transfer the physical control of another major river into India's hands. India's track record of the Farakka Barrage disqualifies her for this proposal. Finally, the lowest recorded flow of the Brahmaputra being only 3,117 cu m/s. the piracy of $2,800 \mathrm{cu} \mathrm{m} / \mathrm{s}$ as proposed by India would leave only $317 \mathrm{cu} \mathrm{m} / \mathrm{s}$ for the $13-\mathrm{km}$ wide river. The consequences would be more disastrous than the Ganges Basin (Sufian, 1993).

Bangladesh side opposed it and proposed for the construction of reservoirs in India and Nepal. Bangladesh proposed an integrated basin development consisting of storage dams in the upper reaches of the Ganges. The monsoon season water could be conserved in these reservoirs for release during the dry season. In addition to generating a tremendous amount of hydropower, it is internationally recognized that the construction of major storage dams within the Ganges and the Brahmaputra basins offers advantages of flood control, as well as reduced sedimentation and increased dry season flows for enhanced agricultural production. The feasibility studies of three such projects viz., the Kosi High Dam, the Karnali Multipurpose, and the Punchesshwar proects had already been completed. The Karnali Project alone could produce 10,000 MW of hydropower, irrigate 32,000 sq km land in India and 2,023 sq $\mathrm{km}$ land in Nepal, and increase the dry season flow by $991 \mathrm{cu}$ $\mathrm{m} / \mathrm{s}$. India did not like the proposal because she does not want tripartite agreement involving Nepal and Bangladesh, and insists on a bilateral agreement, and later follows unilateral decisions as the Farakka record shows (Sufian, 1993). 


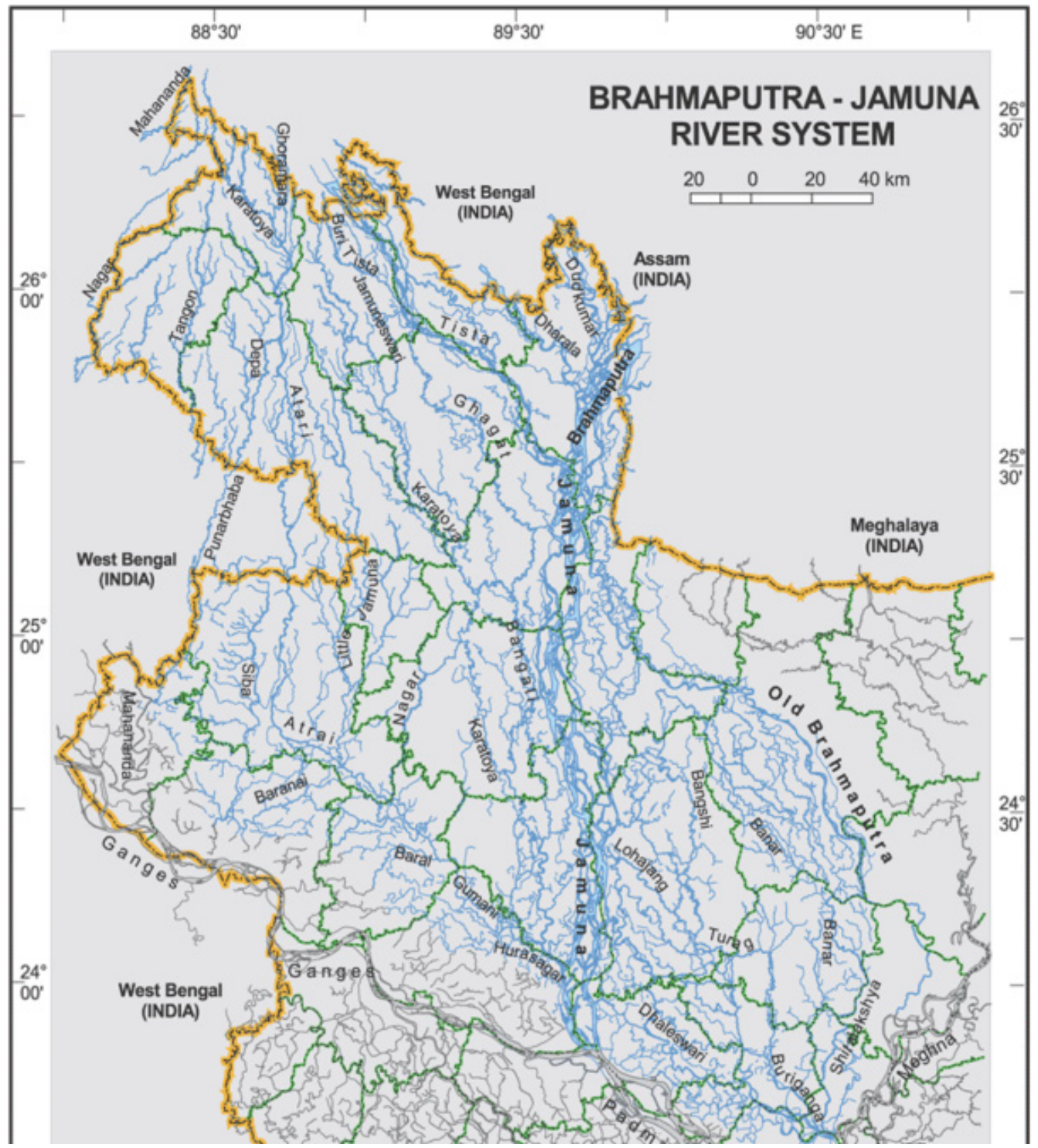

Figure 10. The Brahmaputra Basin in Bangladesh. The link canal originating from Assam would pass over several rivers even it was going along the $26^{\circ}$ parallel (www.banglapedia.org/HT/B_0616.HTM).

\subsubsection{India's Highhandedness}

In a ministerial level conference on 24-25 February 1975 in Delhi, Bangladesh proposed to reduce the flow in the Hooghly during the dry season. Indian side said that Bangladesh did not have any urgency of water which was a strange statement from the Indian side. Indian officials were befooling the newly-borne Bangladeshi officials at the dawn of her independence when the war-torn country lacked many infrastructures in place. The two sides opposed each other's proposals on the issues of the construction of link canal and reservoirs. The meeting ended in dissension between the parties.

The $2^{\text {nd }}$ Ministerial level meeting was held on 16-18 April 1975 in Dhaka. The Indian side slapped on the conference table and demanded $1,132 \mathrm{~m}^{3} / \mathrm{s}$ flow for the Hooghly, violating the etiquettes of the conference. However, she could reduce the flow by only $141.5 \mathrm{~m}^{3} / \mathrm{s}$, but still with a right to piracy at hand. Prior to this meeting, India informed
Bangladesh of her decision to start the operation of the feeder canal on an experimental basis. Bangladesh gave a courteously positive response just because India helped her in the struggle for independence in 1971. Indian interests were two folds - the political one was weakening her arch enemy Pakistan by separating East Pakistan from her and the economic one was to capture the downstream water resources flowing through Bangladesh and to gain the market of 150 million Bangladeshis in trading commodities, education, medical sector assistance, tourism, mini pilgrimage, culture and recreation, etc. etc. Bangladesh was forced to sign, for fear of being cornered, to the understanding that later came out as a press release according to which India could pirate water for the Hooghly for periods of ten days from 21 April to 31 May 1975 according to table 3 below. The same table mentions the pirated water shares according to the no-otheralternative-based consent signed in 1977 and 1996 for 
making comparison (Daily Dinkal, 1996; Daily Janakantha, 1996; Rahman, 1997; Sattar, 1998; Haque, 2003).

Table 3. India's Increasing Share in the Ganges Water Settlement

$\begin{array}{cccc}\text { Withdrawal } & \text { Ad hoc } & \begin{array}{c}5 \text {-Year } \\ \text { Treaty }\end{array} & \begin{array}{c}\text { 30-Year } \\ \text { Treaty }\end{array} \\ \text { Period } & \text { Agreement } & \begin{array}{c}1977-82 \\ \text { Nov }\end{array} & \begin{array}{c}1977-82 \\ \text { Jan } 1997-2027\end{array} \\ & 4 / 21-5 / 31 / 75 & \begin{array}{c}\text { 1977-82 } \\ \left(\mathrm{m}^{3} / \mathrm{s}\right)\end{array} & \left(\mathrm{m}^{3} / \mathrm{s}\right) \\ \text { April 21-30 } & \left(\mathrm{m}^{3} / \mathrm{s}\right) & 566 & 735.6 \\ \text { May 01-10 } & 311 & 608.5 & 990.5 \\ \text { May 11- 20 } & 424.5 & 679.2 & 1,092 \\ \text { May 21-30 } & 452.8 & 757 & 1,132\end{array}$

\subsubsection{Piracy-Based Water Sharing}

India's water share from the Ganges basin to the unconnected Hooghly River basin both in the courteous adhoc consent and in the forced consent (because otherwise Bangladesh is cornered) are mentioned in table 3 in the Appendix. It is seen that the India's share of pirated water has been consistently increasing since the commissioning of Farakka Barrage. In other words, lesser and lesser water is left to flow in Bangladesh.

\subsubsection{India's Bilateral Agreement Upgrading to Unilateral Piracy}

To the surprise of Bangladesh, India continued to pirate the Ganges water for the Hooghly River unilaterally beyond the forty-one days until 1977 without any respect for the downstream country's water right.

JRC held its $13^{\text {th }}$ meeting in Dhaka on 19 June 1975. JRC held discussion on increasing the Ganges flow in its $9^{\text {th }}$ through $13^{\text {th }}$ meeting. Both the parties failed to reach a unanimous decision. Bangladesh did not approve the link canal proposal.

Bangladesh had a new government in August 1975. Bangladesh government sent two letters to the Indian counterpart - one after 18 December 1975 and the other on 3 February 1976 - strongly protesting against India's unilateral water piracy. Indian government replied on 11 February 1976 indicating her consent to discuss the water piracy at the time of the weakest flow of the Ganges only during the dry season. Bangladesh did not agree to discuss with audacious India until she stopped unilateral piracy of water.

India sent an expert delegation to observe the widespread effects of water diversion at the invitation of Bangladesh. The delegation stayed in Bangladesh during 27 April through 2 May 1976. Similarly, a Bangladesh delegation visited the Hooghly and Farakka during 6 May through 11 May 1976. But the exchange of the observant delegation did not produce any result. India unilaterally pirated water the entire season. It was too soon to observe the ecosystem's reaction by the Indian counterpart in Bangladesh. On the contrary, Bangladeshi team observed water abundance in the Hooghly that was deprived of the inflow of water because of locking it in the reservoirs built on the Hooghly's tributaries and sub-tributaries.

\subsubsection{Bangladesh's Approach to the UN}

Bangladesh decided to raise the water piracy at the UN General Assembly. In the meantime, Bangladesh joined a meeting in New Delhi during 7 through 10 September 1976 at the invitation of India. The meeting ended without any progress.

Bangladesh raised the Farakka issue in the $31^{\text {st }} \mathrm{UN}$ General Assembly on 23 September 1976. It was the $121^{\text {st }}$ of the 122 issues discussed in the assembly. Bangladesh proposed a discussion of the issue at the Special Political Committee which was approved by the General Assembly on 24 September 1976. Before the discussion took place, a number of non-aligned nations took some steps to reach an understanding between Bangladesh and India. Special political committee approved the statement of the understanding. In the perspective of the understanding, a ministerial level talk was held on 6 December 1976 in Dhaka and it continued up to 9 December. The second level of talk was held on 14 through 16 December in Dhaka, but without any success. Another Ministerial level talk was held on 21 22 June 1977 in New Delhi without any result in favor of Bangladesh. (Sattar, 1998)

In the meantime, UN organized a water conference on 18 March 1977 in Mardel, Argentina for 8 days. The conference ended with a resolution to preserve the interest of downstream countries which was somewhat favorable for Bangladesh.

A new political party came in power in India on 1 March 1977. The new Indian Defense Minister came to Dhaka on 15 April 1977 to hold talks for three days with Bangladesh. The talks resulted in an understanding later followed by three meetings - 7 - 11 May 1977 in New Delhi, 29 - 31 July and 2 - 6 August 1977 in Dhaka, and 20-30 September 1977 in New Delhi. The Ganges water piracy consent was signed on 5 November 1977.

\subsubsection{Bangladesh Swallowing the Bitter Pill and India's Sensational Reactions}

According to this forced consent, during the weakest flow time in the last ten days of April, out of the $1,557 \mathrm{~m}^{3} / \mathrm{s}$ flow at Farakka, Bangladesh would receive $976 \mathrm{~m}^{3} / \mathrm{s}$ and India 574 $\mathrm{m}^{3} / \mathrm{s}$. If for any reasons, the flow at the Farakka point fell below $1,557 \mathrm{~m}^{3} / \mathrm{s}$, Bangladesh would receive $80 \%$ of her share i. e., 781 of $1,557 \mathrm{~m}^{3} / \mathrm{s}$. Table

3 mentions the India's pirated amount of water at ten days' intervals during 1 January through 31 May. Instead of appreciation, Bangladesh was subjected to heinous comments by the dailies published from Calcutta - the Anandbazar on August 28, 29, 1978; the Satyakatha on August 8, 1980; the Zugantar on January 12, 1981, etc. etc. after yielding to Indian demand. Those editorials expressed Indian attitude to pirate the Ganges water as if the international river water is for India only. Such sensational comments were not befitting for a large nation toward its small neighbor who had been trying so hard to defend her 
water rights. This occurred because pirates never think for the victims. The worst effect of the 10-days interval share of the Ganges water is the inland intrusion of the saline water front in the Bangladesh's coastal areas and extinction and endangerment of the coastal sweet water aquatics.

\subsubsection{Short-Term Compelled Memoranda of Understanding and Waterless Years}

Later, a memorandum of understanding was signed between the two countries on October 7, 1982. The guaranty clause on $80 \%$ of the minimum flow through Bangladesh was dropped from the understanding. The second memorandum of understanding was similar to the one of 1982 and was signed by the two countries in 1985. It ended on May 31, 1988. No treaty was operational during 1988-96. India unilaterally pirated the Ganges water during the dry season for those eight straight years causing ecocidal effects in Bangladsh (Adel, 1999, 2001, 2003, 2005). Water is the elixir for the ecosystem. It is worse than the weapon of mass destruction in cornering the victim country.

In Bangladesh, a new political party came in power in March 1991. A two-day meeting was held in Dhaka on 23 April 1991. It was decided to prioritize the water sharing of the Ganges and another international river the Tista. In a meeting in August 1991, Indian foreign secretary proposed for a permanent solution of water sharing problem from the Ganges, the Brahmaputra, the Tista, and the Meghna. In the secretarial level meeting on 2 February 1992 in Dhaka, no understanding was reached on the sharing of the Ganges and the Tista water. However, both parties agreed to continue further discussion. On 21-22 April 1992, a ministerial level meeting was held in New Delhi on the sharing of international river water. Bangladesh proposed to solve the water diversion issue from the Ganges and the Tista. Being cornered, she could only propose to her obstinate neighbor.

On 26-28 May 1992, the premiers of Bangladesh and India met in New Delhi and agreed to work for a long term settlement of the water sharing issue of the common rivers. Indian Premier said of taking steps to avoid the sufferings of Bangladesh by sharing of the Ganges water. But India took no such steps. The ministerial level meeting of 29-30 March 1993 ended in vain due to the obstinate nature of India. During the Southeast Asia Regional Corporation (SARC) meeting on 11 April 1993, the premiers of Bangladesh and India decided to meet soon to work on the issue of water sharing. Later, that meeting was never meeting was held. India was only buying time. Bangladesh's insurmountable problems of water scarcity, fatality- and morbidity-causing arsenic poisoning of potable groundwater, summer time excessive heat, winter time excessive cold, aquatic species extinction, and mass mal-nutrition because of the depletion of the fish resources, coastal erosion and inland intrusion of the saline waterfront were mounting as the ecosystem was continuously deprived of water. On the contrary, Indian coast was being built and protected from salinity intrusion.

\subsubsection{Bangladesh's Second Approach to the UN}

Bangladesh Premier raised the Farakka issue at the $48^{\text {th }}$ General Assembly on 1 October 1993. Again the Bangladeshi Premier met the India Premier on 2-4 May 1995 in the SARC meeting in New Delhi. The Bangladeshi Premier, as usual, received the assurance from the Indian counter part. On 24 June 1995, a Secretarial level meeting was held in Dhaka in which the sharing of water from transboundary rivers was given due importance. Also, a decision was made to monitor the flow at four points of the Ganges.

Bangladesh Premier again raised the issue on 23 October 1995 at the $50^{\text {th }}$ anniversary of the UN. A pen picture of the sufferings of the Bangladeshi people was portrayed.

\subsubsection{India's Inclination to a Specific Political Party and not the People in Bangladesh}

Government changed in Bangladesh in 1996. The new government tried for 6 months in 11 meetings at the levels of ministers, secretaries, and experts. The first meeting was held on 5-7 July 1996 in Dhaka at the secretarial level. Bangladesh water resources minister left for New Delhi on 29 October 1996 to meet with his counterpart. Later, he met other high level officials and the Indian Premier. Bangladeshi foreign minister held talks with the Indian counterpart for three days beginning on 9 November 1996. Both of them expressed hopes for fair sharing of the Ganges water before the onset of the dry season

Bangladeshi premier held a courtesy meeting with the Indian Premier on 17 November 1996 in Rome in the World Food meeting. The Chief Minister of West Bengal came to Dhaka on 27 November 1996 for a six-day visit. He gave indications of the solution to the water sharing problem. Bangladesh Premier went to India on 10 December 1996, and held talks with her counterpart on 11 December, again. At last, after 21 years of procrastination on the Indian side, an Indian water piracy treaty was signed between the two governments for 30 years on 12 December 1996 in the Hyderabad House. The discharges in the Ganges up to the treaty time are shown in Fig. 11. Water shortage left its impression in the irreparable losses in many known and unknown sectors of the downstream country (Adel, 1999, $2001,2002,2003,2005,2008)$. 


\section{COMPARISON OF PRE- AND POST-FARAKKA ANNUAL AVERAGE DISCHARGES THROUGH THE DELTA}

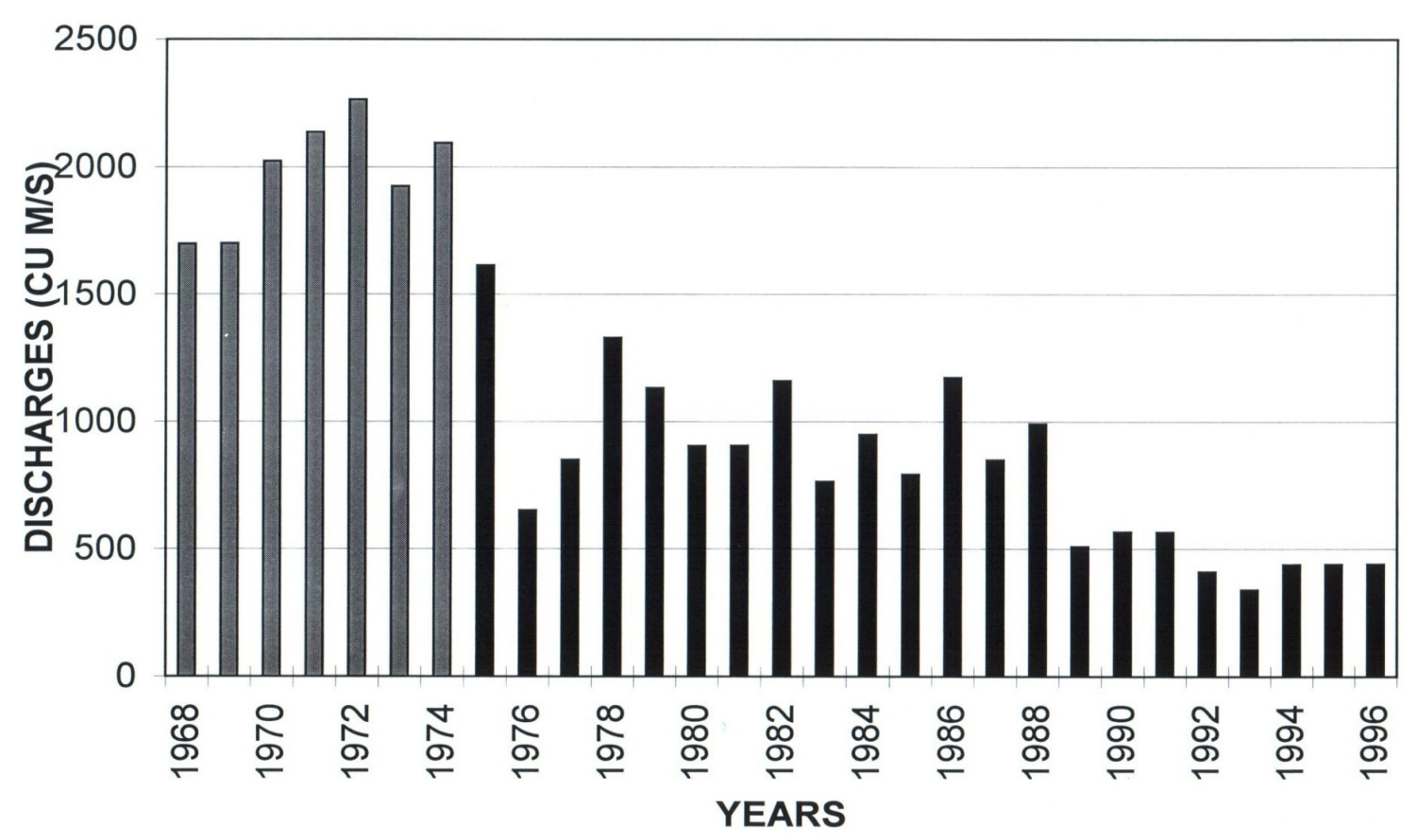

Figure 11. The dwindling flow in the Ganges in Bangladesh has lost 60\% of her virgin flow (Hebblethwaite, 1997).

Even though India got the green card for water piracy, she started stealing water in the darkness of night, as she did in the past (Begum, 1988), and blamed the solar radiation for not being strong enough to melt the Himalayan ice (Burns, 1997) The two Indian water piracy authorizations of 1977 and 1996 have been compared in Figs. 12a and 12b. Whereas the average flow through the Hoghly/Bhagirathi is increasing for India, it is decreasing through the Bangladesh Ganges in the dry season. The piracy treaty lacks a guaranty clause for the fair share of Bangladesh. If the discharge at the Farakka point drops below 1,500 $\mathrm{m}^{3} / \mathrm{s}$, the treaty will not work and Bangladesh have to meet with her counterpart an unknown number of times to come to a settlement for her survivability and avoidance of cornering. It is mentionable that 87 meetings were held up until December 12,1996 . It is thought that no more treaty will be required when the current one ends because of unavailability of water at the Farakka point for increased piracy at the upstream via construction of dams and barrages as illustrated in Figs. 8 and 9. All these bilateral scheduled meetings have been mentioned in table 4 for information of the international readers.

Table 4. Indo-Bangladesh Marathon Meetings

\begin{tabular}{|c|c|c|c|c|}
\hline \multicolumn{2}{|c|}{ \# Level of Meeting } & Place & \multicolumn{2}{|c|}{ Duration } \\
\hline 1 st & $\mathrm{JRC}$ & New Delhi & $\begin{array}{l}25-26 \\
1972\end{array}$ & June \\
\hline 2 nd & JRC & Dhaka & $\begin{array}{l}28-30 \\
1972\end{array}$ & Sept. \\
\hline $3 \mathrm{rd}$ & $\mathrm{JRC}$ & New Delhi & $\begin{array}{l}11-13 \\
\text { Decem } \\
1972\end{array}$ & \\
\hline 4th & JRC & Dhaka & $\begin{array}{l}29-31 \\
1973\end{array}$ & March \\
\hline 5 th & $\mathrm{JRC}$ & Dhaka & 27-May & $y-73$ \\
\hline 6th & Ministers & New Delhi & $\begin{array}{l}16-17 \\
1973\end{array}$ & July \\
\hline 7 th & $\mathrm{JRC}$ & New Delhi & $\begin{array}{l}19-21 \\
1973\end{array}$ & July \\
\hline 8th & $\mathrm{JRC}$ & Dhaka & $\begin{array}{l}8-10 \\
1973\end{array}$ & Nov. \\
\hline 9th & Ministers & Dhaka & $\begin{array}{l}10-15 \\
1974\end{array}$ & Feb. \\
\hline 10th & JRC & New Delhi & 28 & Feb.-2 \\
\hline
\end{tabular}




\begin{tabular}{|c|c|c|c|}
\hline & & & Mar'74 \\
\hline 11th & Premiers & New Delhi & $\begin{array}{l}12-16 \quad \text { May } \\
1974\end{array}$ \\
\hline 12th & JRC & Dhaka & $\begin{array}{ll}6-12 & \text { June } \\
1974 & \end{array}$ \\
\hline 13th & JRC & Calcutta & 17-Jul-74 \\
\hline 14th & JRC & Dhaka & $\begin{array}{l}28 \text { Aug. -2 } \\
\text { Sep'74 }\end{array}$ \\
\hline 15th & $\mathrm{JRC}$ & New Delhi & $\begin{array}{l}28 \mathrm{Sep}-4 \mathrm{Oct} \\
' 74\end{array}$ \\
\hline Postponed & & Dhaka & $\begin{array}{l}16-20 \text { Nov. } \\
1974\end{array}$ \\
\hline 16th & JRC & New Delhi & $\begin{array}{l}31 \text { Dec'74-7 } \\
\text { Jan '75 }\end{array}$ \\
\hline 17 th & Ministers & New Delhi & $\begin{array}{ll}24-25 & \text { Feb. } \\
1975 & \end{array}$ \\
\hline Postponed & & Dhaka & $\begin{array}{l}16-18 \text { April } \\
1975\end{array}$ \\
\hline 18th & JRC & Dhaka & $\begin{array}{ll}19-21 & \text { June } \\
1975 & \end{array}$ \\
\hline 19th & Indian Represent. & Dhaka & $\begin{array}{l}18-22 \\
1976\end{array}$ \\
\hline 20th & Ministers & New Delhi & $\begin{array}{l}7-10 \quad \text { Sept } \\
1976\end{array}$ \\
\hline 21 st & UNO & New York & $\begin{array}{l}23 \quad \text { Sep-26 } \\
\text { Nov '76 } \\
6-9\end{array}$ \\
\hline 22nd & Ministers & Dhaka & $\begin{array}{l}\text { December } \\
1976\end{array}$ \\
\hline $23 \mathrm{rd}$ & Ministers & Dhaka & $\begin{array}{l}14-16 \quad J a n \\
1977\end{array}$ \\
\hline 24th & Ministers & New Delhi & $\begin{array}{l}21-22 \\
\text { January } 1977\end{array}$ \\
\hline 25 th & Ministers & Dhaka & $\begin{array}{l}15-18 \quad \text { April } \\
1977\end{array}$ \\
\hline 26th & High Level & Dhaka & 18-Apr-77 \\
\hline 27 th & Officials & New Delhi & $\begin{array}{ll}6-11 & \text { May } \\
1977 & \end{array}$ \\
\hline 28th & Officials & Dhaka & $\begin{array}{l}28 \text { Jul 6-Aug } \\
1977\end{array}$ \\
\hline 29 st & Officials & New Delhi & $\begin{array}{ll}20-30 \quad \text { Sept } \\
1977\end{array}$ \\
\hline 30th & Ministers & Dhaka & 5-Nov-77 \\
\hline $31 \mathrm{st}$ & President-Premier & New Delhi & 19-Dec-77 \\
\hline 32nd & JRC & Dhaka & $\begin{array}{l}20-24 \quad \text { Jan } \\
1978\end{array}$ \\
\hline $33 \mathrm{rd}$ & $\mathrm{JRC}$ & New Delhi & $\begin{array}{l}5-11 \text { July } \\
1978\end{array}$ \\
\hline 34th & $\mathrm{JRC}$ & Dhaka & $\begin{array}{l}6 \text { Nov, } 8-10 \\
\text { Dec'78 }\end{array}$ \\
\hline 35 th & President-Premier & Dhaka & 16-Apr-79 \\
\hline 36th & JRC & New Delhi & $\begin{array}{l}8-12 \quad \text { May } \\
1979\end{array}$ \\
\hline Postponed & JRC & Dhaka & $\begin{array}{l}16-20 \\
1979\end{array}$ \\
\hline 37 th & $\mathrm{JRC}$ & New Delhi & $\begin{array}{l}20-29 \\
1980\end{array}$ \\
\hline Postponed & JRC & New Delhi & $\begin{array}{l}26-28 \\
1980\end{array}$ \\
\hline 38th & $\mathrm{JRC}$ & Dhaka & $\begin{array}{ll}9-11 & \text { July } \\
1980 & \end{array}$ \\
\hline 39th & $\mathrm{JRC}$ & New Delhi & $\begin{array}{l}29 \text { Aug-1Sep } \\
1980\end{array}$ \\
\hline $\begin{array}{l}\text { 40th } \\
41 \mathrm{st}\end{array}$ & $\begin{array}{l}\text { Ministers } \\
\text { Ministers }\end{array}$ & $\begin{array}{l}\text { Dhaka } \\
\text { New Delhi }\end{array}$ & $\begin{array}{l}\text { 5-7 Nov } 1980 \\
\text { 6-9 Jan } 1981\end{array}$ \\
\hline 42nd & Ministers & Dhaka & $\begin{array}{l}2-4 \\
1981\end{array}$ \\
\hline 43rd & Forgn. Mnstrs. & New Delhi & $11-13$ \\
\hline
\end{tabular}




\begin{tabular}{|c|c|c|c|}
\hline & & & 1981 \\
\hline 44th & $\mathrm{JRC}$ & Dhaka & $\begin{array}{ll}26-28 & F \\
1982 & \end{array}$ \\
\hline 45th & Ministers & New Delhi & $\begin{array}{l}25-29 \\
1982\end{array}$ \\
\hline 46th & JRC & Dhaka & 28-Aug-82 \\
\hline 47th & Ministers & Dhaka & $\begin{array}{l}30-31 \quad \text { Aug } \\
1982\end{array}$ \\
\hline 48th & $\begin{array}{l}\text { President-Premier } \\
\text { New Delhi }\end{array}$ & New Delhi & $\begin{array}{l}\text { 6-9 October } \\
1982\end{array}$ \\
\hline 49th & JRC & New Delhi & $\begin{array}{ll}22-24 & \text { Dec } \\
1982 & \end{array}$ \\
\hline 50th & $\mathrm{JRC}$ & Dhaka & 2-4 Feb 1983 \\
\hline Postponed & JRC & New Delhi & $\begin{array}{ll}22-24 & \text { Feb } \\
1983 & \end{array}$ \\
\hline $51 \mathrm{st}$ & JRC & Dhaka & $\begin{array}{l}18-20 \\
1983\end{array}$ \\
\hline 52nd & $\mathrm{JRC}$ & New Delhi & $\begin{array}{l}13-15 \\
1984\end{array}$ \\
\hline Postponed & $\mathrm{JRC}$ & Dhaka & $\begin{array}{l}29-31 \\
1984\end{array}$ \\
\hline $53 \mathrm{rd}$ & JRC & New Delhi & $\begin{array}{l}14-16 \\
1984\end{array}$ \\
\hline 54th & JRC & Dhaka & $\begin{array}{l}2-4 \\
1985\end{array}$ \\
\hline 55 th & President-Premier & $\begin{array}{l}\text { Nasaw, } \\
\text { Bahamas }\end{array}$ & $18-O c t-85$ \\
\hline 56th & Ministers & New Delhi & $\begin{array}{l}18-22 \\
1985\end{array}$ \\
\hline 57 th & $\begin{array}{l}\text { Joint Exprts Cmmt. } \\
\text { Dhaka }\end{array}$ & Dhaka & $\begin{array}{l}16-18 \\
1986\end{array}$ \\
\hline 58th & JEC & New Delhi & $\begin{array}{l}27-28 \\
1986\end{array}$ \\
\hline $\begin{array}{l}\text { 59th } \\
\text { 60th }\end{array}$ & $\begin{array}{l}\text { JEC } \\
\text { JEC }\end{array}$ & $\begin{array}{l}\text { Dhaka } \\
\text { New Delhi }\end{array}$ & $\begin{array}{l}\text { 2-3 July } 1986 \\
\text { 4-5 Aug } 1986\end{array}$ \\
\hline 61 st & JEC & Dhaka & $\begin{array}{l}25-26 \quad \text { Aug } \\
1986\end{array}$ \\
\hline $62 \mathrm{nd}$ & Ministers & Dhaka & $\begin{array}{l}27-28 \quad \text { Aug } \\
1986\end{array}$ \\
\hline 63rd & JEC & New Delhi & $\begin{array}{l}3-4 \text { October } \\
1986\end{array}$ \\
\hline 64th & JEC & $\begin{array}{l}\text { Kathmandu, } \\
\text { Nepal }\end{array}$ & $\begin{array}{ll}29-31 & O \\
1986 & \end{array}$ \\
\hline 65th & Ministers & New Delhi & 13-Nov-86 \\
\hline 66th & President-Premier & $\begin{array}{l}\text { Bangalore, } \\
\text { India }\end{array}$ & 17-Nov-86 \\
\hline 67 th & Foreign Ministers & Dhaka & $\begin{array}{l}\text { 6-Jan-87 } \\
\text { 17-Jan-87 }\end{array}$ \\
\hline 69th & Foreign Ministers & Kathmandu & $\begin{array}{l}\text { 17-Jan-87 } \\
3-4 \quad \text { May } \\
1987\end{array}$ \\
\hline $\begin{array}{l}70 \text { th } \\
71 \mathrm{st}\end{array}$ & $\begin{array}{l}\text { Ministers } \\
\text { JRC }\end{array}$ & $\begin{array}{l}\text { New Delhi } \\
\text { New Delhi }\end{array}$ & $\begin{array}{l}10-\text { May-87 } \\
11 \text {-May-87 }\end{array}$ \\
\hline $72 \mathrm{nd}$ & JEC & New Delhi & $\begin{array}{l}20-21 \quad \text { Nov } \\
1987\end{array}$ \\
\hline 73rd & President-Premier & New Delhi & 29-Sep-88 \\
\hline 74th & Ministers & Dhaka & $\begin{array}{ll}16-18 & \text { Feb } \\
1990 & \end{array}$ \\
\hline 75th & JRC & New Delhi & $\begin{array}{l}18-19 \text { April } \\
1990\end{array}$ \\
\hline 76th & Secretaries & Dhaka & 21-Jun-90 \\
\hline 77th & $\mathrm{JRC}$ & Dhaka & $\begin{array}{ll}21-22 & \text { Jun } \\
1990 & \end{array}$ \\
\hline 78th & Secretaries & New Delhi & 2-3 Oct 1990 \\
\hline 79th & Secretaries & Dhaka & $\begin{array}{l}23-24 \quad \text { April } \\
1991\end{array}$ \\
\hline 80th & Secretaries & New Delhi & 27-Aug-91 \\
\hline 81 st & Secretaries & New Delhi & $\begin{array}{l}10-11 \quad \text { Oct } \\
1991\end{array}$ \\
\hline
\end{tabular}




\begin{tabular}{|c|c|c|c|}
\hline $82 \mathrm{nd}$ & Secretaries & Dhaka & 2-Feb-92 \\
\hline 83rd & Secretaries & New Delhi & $\begin{array}{l}21-22 \quad \text { April } \\
1992\end{array}$ \\
\hline 84th & Premiers & New Delhi & $\begin{array}{l}26-28 \quad \text { May } \\
1992\end{array}$ \\
\hline 85th & Ministers & Dhaka & $\begin{array}{l}26-27 \\
1992\end{array}$ \\
\hline 86th & JEC & Dhaka & $\begin{array}{l}30-31 \\
1993\end{array}$ \\
\hline $\begin{array}{l}\text { 87th } \\
\text { 88th }\end{array}$ & $\begin{array}{l}\text { Premiers } \\
\text { Premiers }\end{array}$ & $\begin{array}{l}\text { Dhaka } \\
\text { Kathmandu }\end{array}$ & $\begin{array}{l}\text { 11-Apr-93 } \\
23-N o v-93\end{array}$ \\
\hline 89th & Premiers & New Delhi & $\begin{array}{ll}2-4 & \text { May } \\
1995 & \end{array}$ \\
\hline 90th & Foreign Secretaries & New Delhi & 4-May-95 \\
\hline 91st & Secretaries & Dhaka & 24-Jun-95 \\
\hline 92nd & Foreign Sec. & Dhaka & 5-7 July 1996 \\
\hline 93rd & Secretaries & New Delhi & 6-9 Aug 1996 \\
\hline 94th & Ministers & Dhaka & 6-9 Sep 1996 \\
\hline 95th & Ministers & Calcutta & 17-Sep-96 \\
\hline 96th & Experts & Calcutta & $\begin{array}{ll}27-28 & \text { Sep } \\
1996 & \end{array}$ \\
\hline 97th & Ministers & New Delhi & $\begin{array}{l}29 \text { Oct-2 Nov } \\
1996\end{array}$ \\
\hline 98th & Ministers & New Delhi & $\begin{array}{l}9-11 \\
1996\end{array} \quad$ Nov \\
\hline 99th & Premiers & Rome & 17-Nov-96 \\
\hline 100th & Ministers & Dhaka & $\begin{array}{l}27 \quad \text { Nov-2 } \\
\text { Dec } 1996\end{array}$ \\
\hline 101 st & Secretaries & New Delhi & 4-Dec-96 \\
\hline $102 \mathrm{nd}$ & Premiers & New Delhi & $\begin{array}{l}10-12 \quad \text { Dec } \\
1996\end{array}$ \\
\hline
\end{tabular}

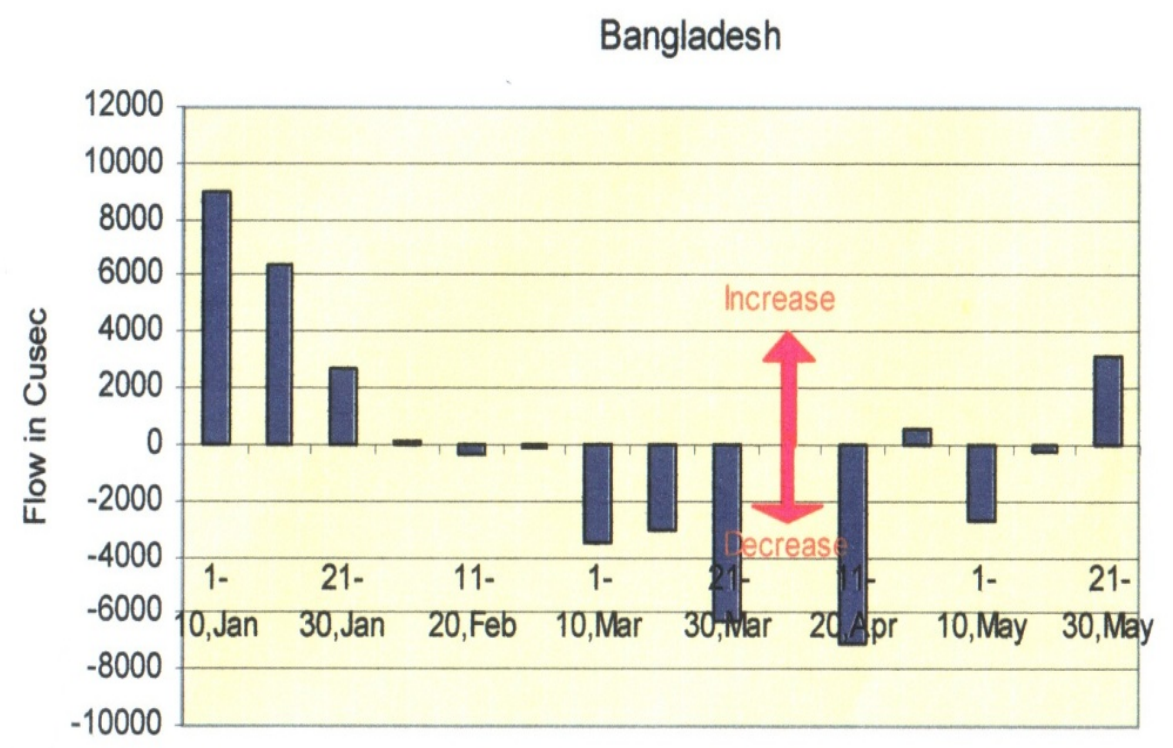

Figure 13a. 1996 ever-decreasing dry season water share for Bangladesh relative to the 1977 Indian water piracy agreement (Courtesy of Hossain et al., 2003) 


\section{India}

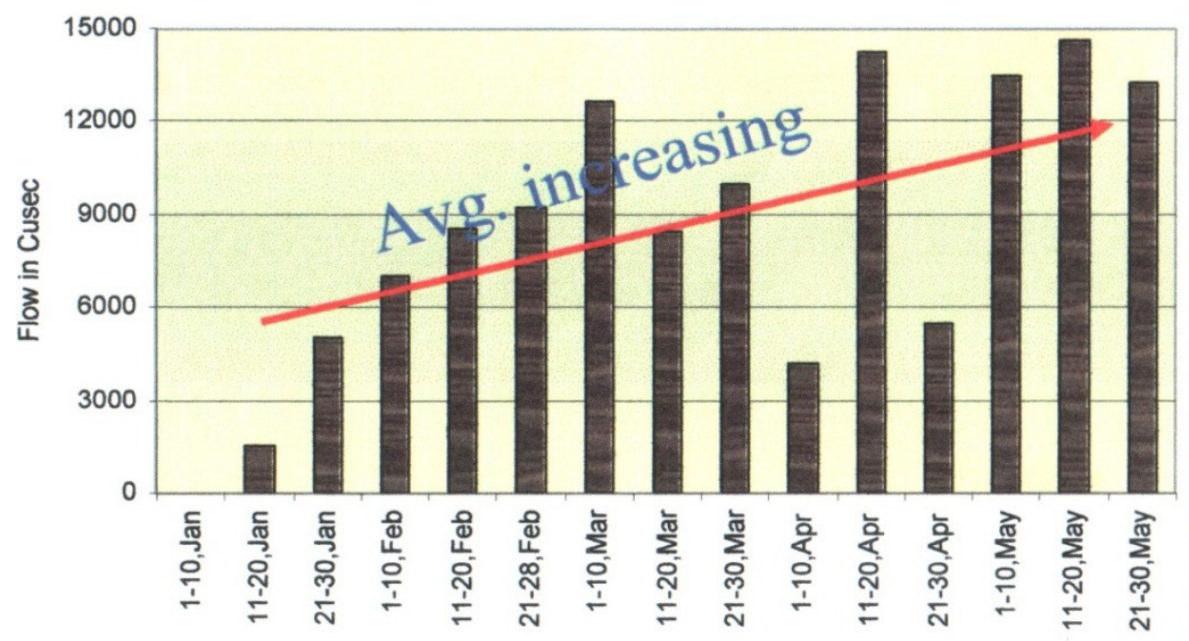

Figure 13b. 1996 ever-increasing dry season water share for India relative to the 1977 water piracy agreement (Courtesy of Hossain et al., 2003)

\subsection{Ecocide Effects}

It is quite unimaginable if $60 \%$ of the water requirement of a wetland ecology is cut short. It never happened in the history of mankind by anthropogenic actions. However, it happened in Southeast Asia and was done by a rising economic power. The details of the ecocide effects are given below.

\subsubsection{Depletion of the Aquatic Habitats}

Unilateral water piracy at the upstream for straight 8 years dried up the Ganges downstream. Fig. 14 shows the condition of the world's $8^{\text {th }}$ largest river the Ganges. Deep fissures in between dried-up land masses in the Ganges bed and shoals near the Hardinge Bridge never appeared before. The silted, raised, and contracted Ganges bed has virtually reduced its depth and width. The bottom two insets are the dry season pictures of the Ganges by the largest riparian city Rajshahi in Bangladesh. The evolving morphology of Ganges has reduced drastically its flood season water carrying capacity. India releases the dam/barrage gates during the flood season all on a sudden that causes irreparable loss to lives and properties in Bangladesh.
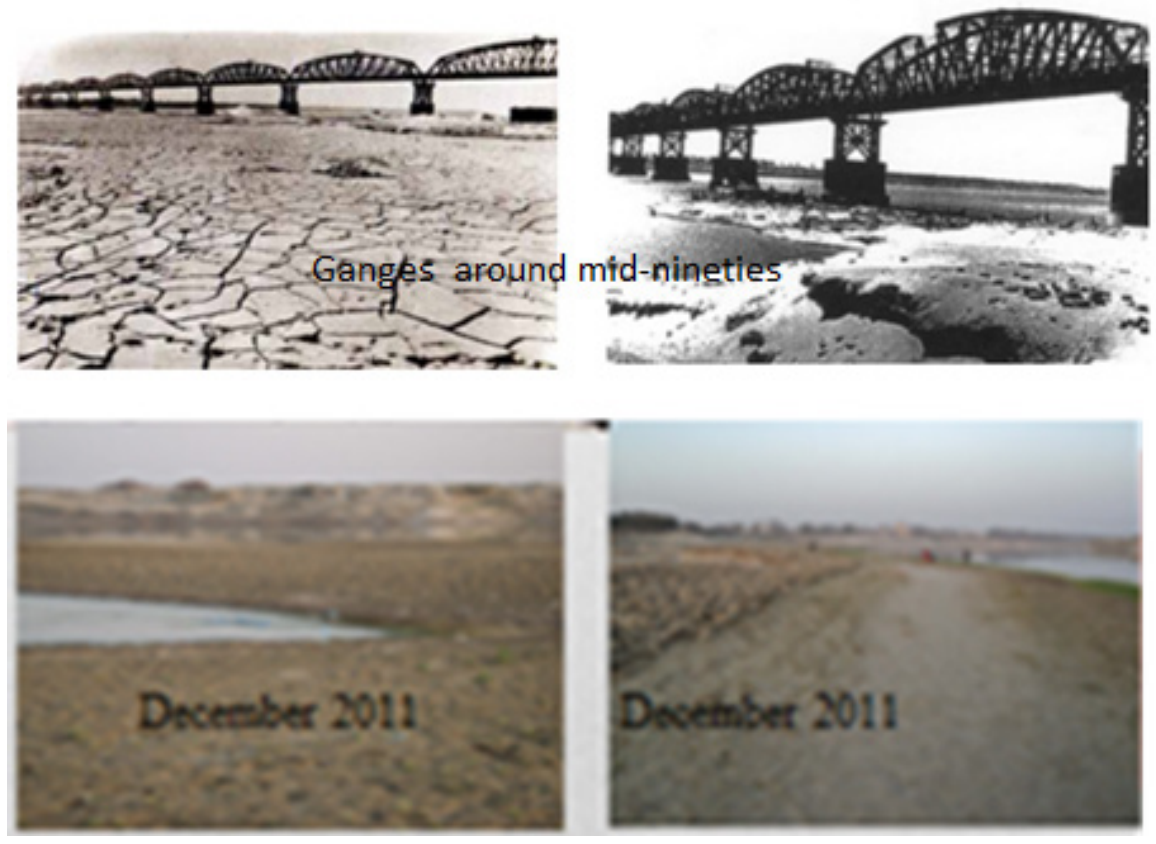

Figure 14. The top two pictures describes the condition of the Ganges in about the mid-nineties by the Hardinge Bridge (Courtesy of Salahuddin, 1996). The bottom two insets how the condition by the largest riparian city Rajshahi in Bangladesh (Courtesy of Jebuni and Sadequl, December 2011). 
With the dwindling flow in the Ganges, its distributaries' origins have been clogged letting no water discharge through them. Fig. 15 shows the condition of the Baral distributary, the Ganges' first distributary, and its distributary Musa Khan along with canals, floodplains, and ponds. In the pre-piracy period, these dried up natural and artificial containers of water had been quite deep and wide to accommodate a huge amount of water for the wetland ecosystem. Numerous aquatics and amphibians have been extinct before an inventory could be made. These water bodies were the wells for recharging groundwater as well as the abode for the by-gone fish resources. Table 5 gives a partial list of about 40 villages from the both banks of the Musa Khan where the villagers never thought of digging ponds to meet their surface water resources.

Table 5. Villages by the Bank of the Musa Khan

$\begin{array}{ll}\text { 1. Buiervag } & \text { 20. Raipara } \\ \text { 2. Agh Digha } & \text { 21. Joyrampur } \\ \text { 3. Mach Digha } & \text { 22. Paik Para } \\ \text { 4. Diar Kazipur } & \text { 23. Peergasa } \\ \text { 5. Katua Gasi } & \text { 24. Jele Para (Horback) } \\ \text { 6. Telkupi } & \text { 25. Baroipara } \\ \text { 7. Madan Hati } & \text { 26. Karamdoshi } \\ \text { 8. Dighapotia } & \text { 27. Jagirpara } \\ \text { 9. Vaturia } & \text { 28. Omorgari } \\ \text { 10.Bakshal } & \text { 29. Hapania } \\ \text { 11.Jholmolis } & \text { 30. Poket Khali } \\ \text { 12. Khejurtola } & \text { 31. Dangapara } \\ \text { 13. Bilmaria } & \text { 32. Madhukhali } \\ \text { 14. Harogathi } & \text { 33. Tegachi } \\ \text { 15.Gang Dhopapara } & \text { 34. Noldapara } \\ \text { 16.Nokul Baria } & \text { 35. Basudevpur } \\ \text { 17.Jew Para } & \text { 36. Patul Hapani } \\ \text { 18. Kanai Para } & \text { 37. Syedpur } \\ \text { 19.Kathal Baria } & \text { 38. Par Omargari }\end{array}$
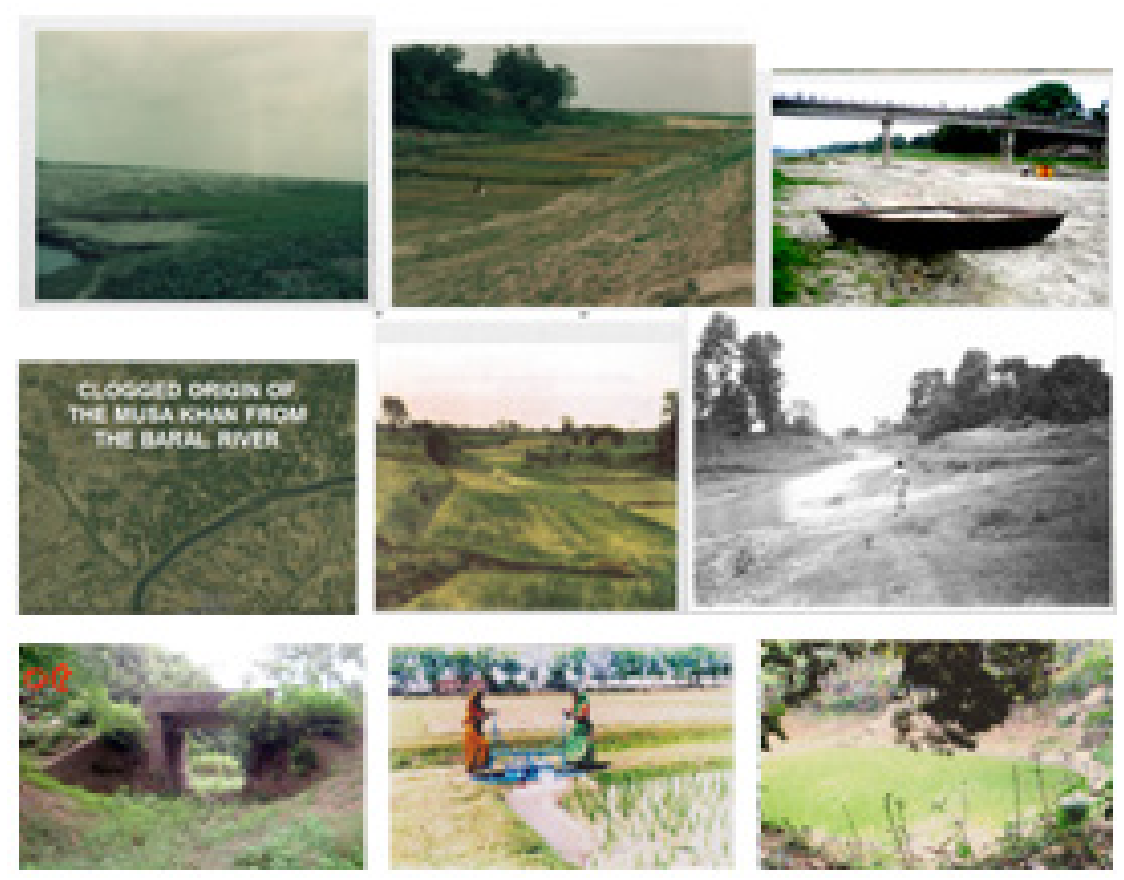

Figure 15. Top row: A huge shoal at the origin of the Ganges's primary distributary the Baral (left) (Courtesy of A. Samad); the Baral's clogged mouth (middle) (Courtesy of A. Samad', the Baral's condition in its mid-course (right) (Courtesy of Amar Desh, a Bengalidaily),. Middle row: The Baral turns to the right and the secondary distributary Musa Khan to the left (left) (Courtesy of Google); the clogged mouth of the Musa Khan (middle) (Courtesy of A. Samad); a mid-course condition of the Musa Khan (right) (Courtesy of A. Samad). Bottom row: A culvert over a decades-long clogged canal from the Musa Khan to carry water to interior floodplains (left) (Courtesy of A. Samad); groundwater is extracted in a dry floodplain for rice cultivation (middle) (courtesy of anonymous photographer); rice planted in the author's dry family pond (right) (Courtesy of A. Samad), the deepest family pond of the locality that served year-round dozens of families in pre-piracy period turned dry .

Other distributaries and sub-distributaries face similar situation. Fig. 16 shows the silted bed of the Garai distributary and the sub-distributary Kali Ganga. The bottom inset shows the ever-decreasing flow in the Garai. Water bodies like canals, floodplains, ponds, and ditches have similarly dried up in the Garai basin. 

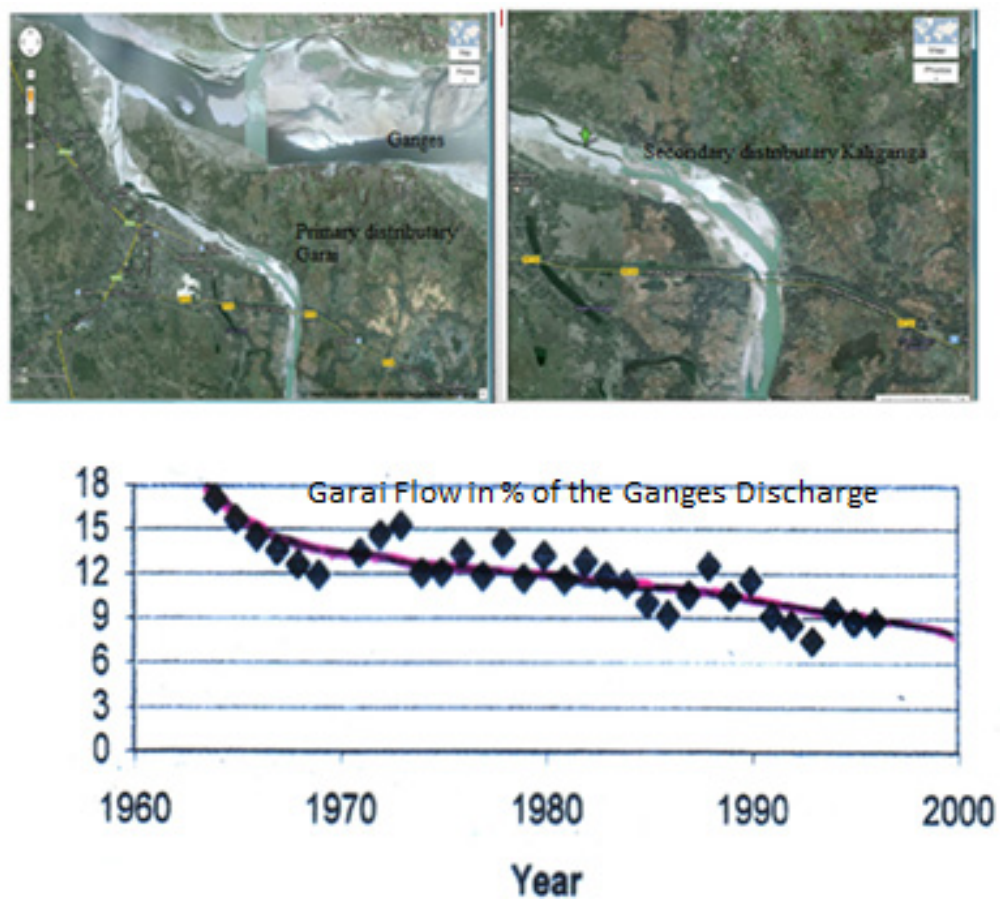

Figure 16. The condition of the primary distributary Garai (top left inset) and the secondary distributary Kaliganga (top right inset) of the Ganges (Courtesy of Googles). The Garai discharge is almost half of what had been in the pre-piracy period (modified after Hossain et al., 2003)

\subsubsection{Depletion of Fish Resources}

Rice and fish had been the staple food for the Bangladeshis. For about six months, people would fish in floodplain areas which turn into public fishing places. People's income would be supplemented with fishing, making fishing gears, and other related tasks. Fish is now out of reach of the common people. Fig. 17 shows the annual fish production in a rural unit in the Musa Khan basin both for the pre-piracy and post-piracy periods.

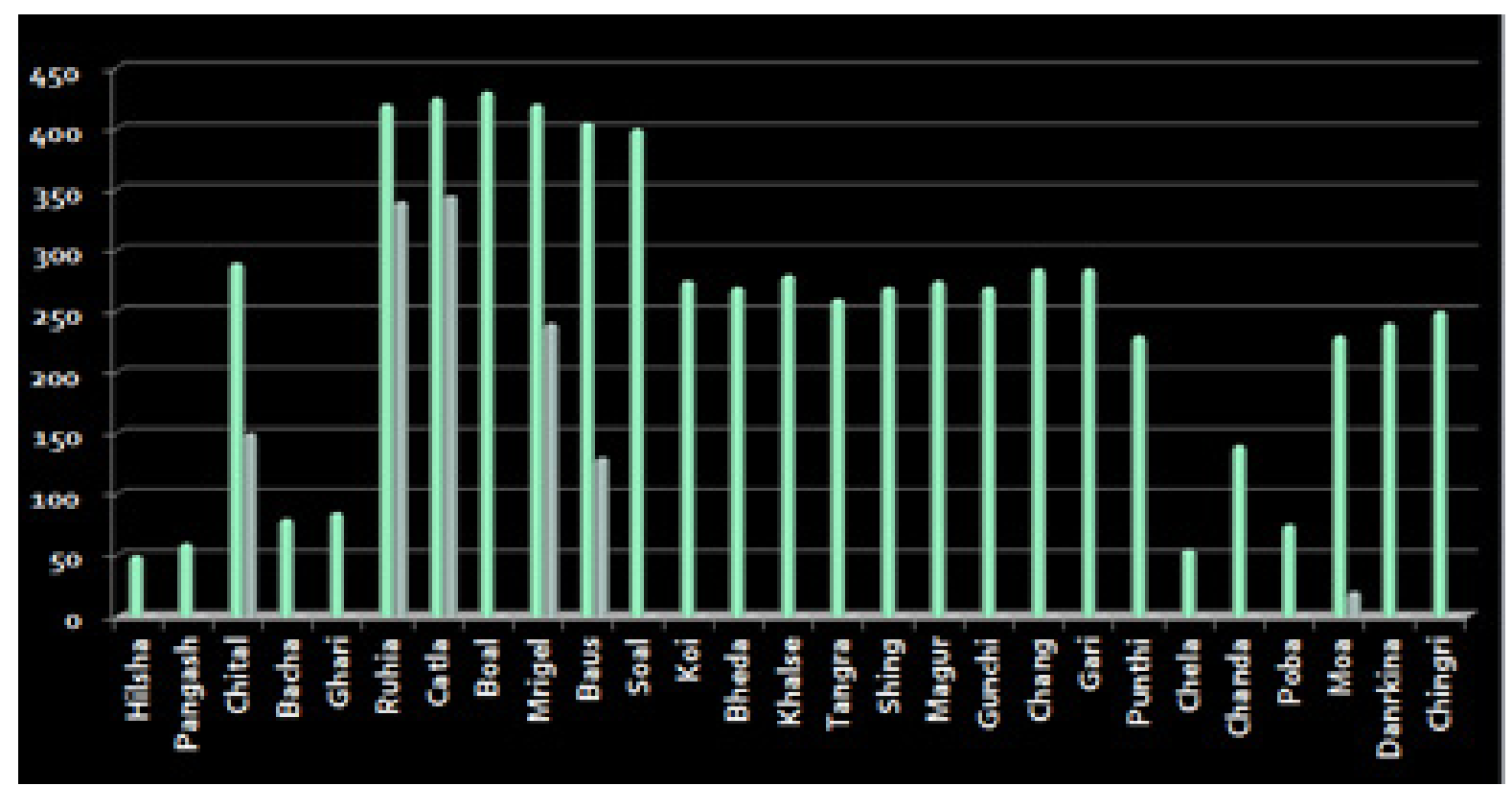

Figure 17. Annual fish production in surface water resources in the Musa Khan basin in pre-piracy (light green) and in the late nineties of the post-piracy ( light grey) period.

Fig. 18 shows the monthly fish catch from different surface water resources. In the absence of flood water, rainfall has become scanty and irregular which is not suitable for fish raising in the temporary surface water resourcing holding little water for short times. 


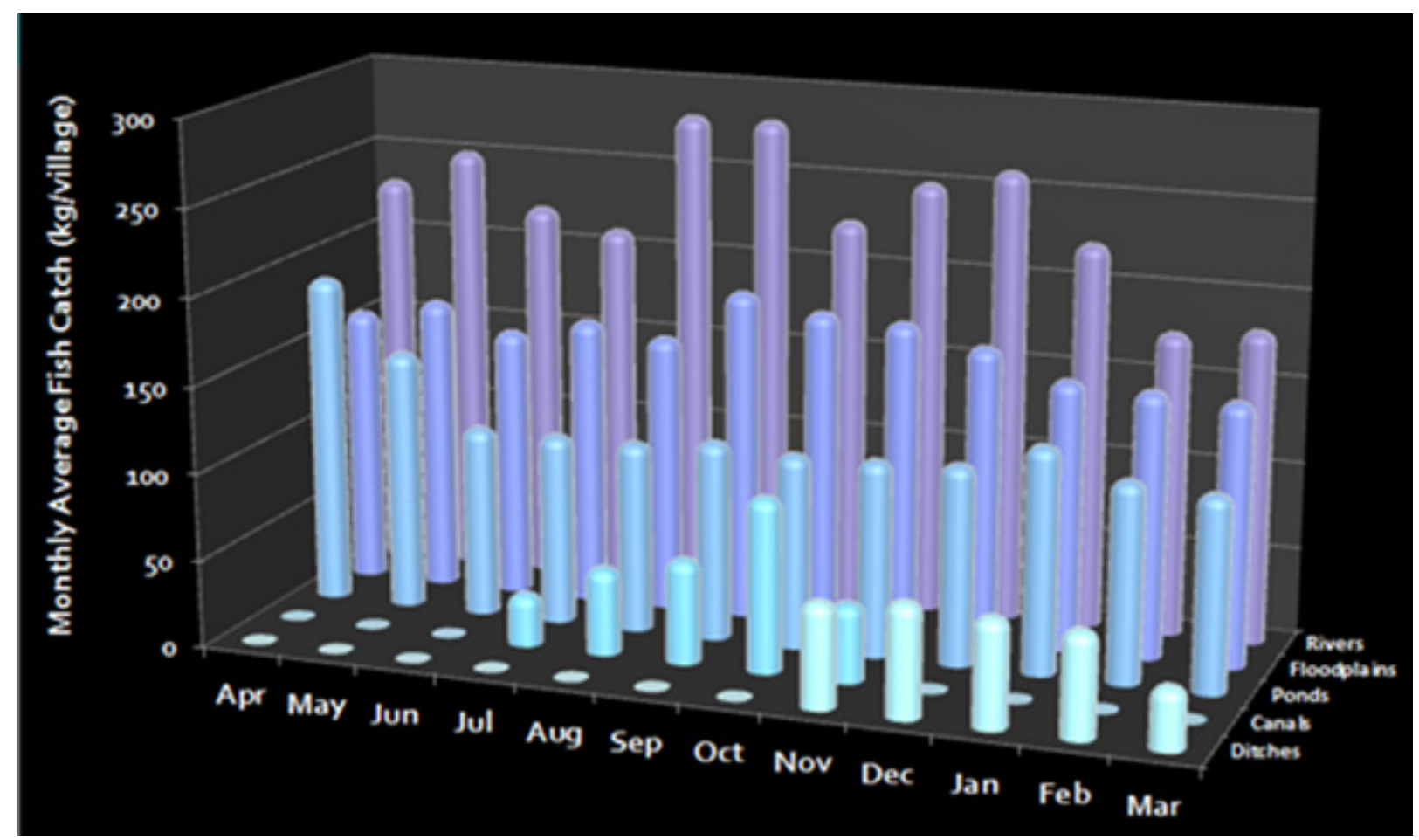

Figure 18. Pre-piracy period monthly fish production from different surface water resouces in a rurual unit

Fish had been the cheapest source of calcium and the indispensable animal protein (Figs. 19 and 20). People suffer from the deficiency of these two nutrients. $99 \%$ of our bones and teeth is calcium. It is very important for growth and maintenance and reproduction. Prolonged calcium deficiency causes rickets, poor blood clotting, and in case of a menopausal woman, osteoporosis. These days even even people complains of back pains.

The syndromes of protein deficiency are weight loss, subcuteneous fat decrease, weakness, muscle wasting edema, and fluid accumulation in serous cavities, hypotension, bradycardia, and pigmentary changes in the skin, and a drop in basal metabolic rate. Subcutaneos fat decrease increases cannot protect ill-clad at-risk population from losing body heat to succumb to death causing extreme winter-related fatilities.

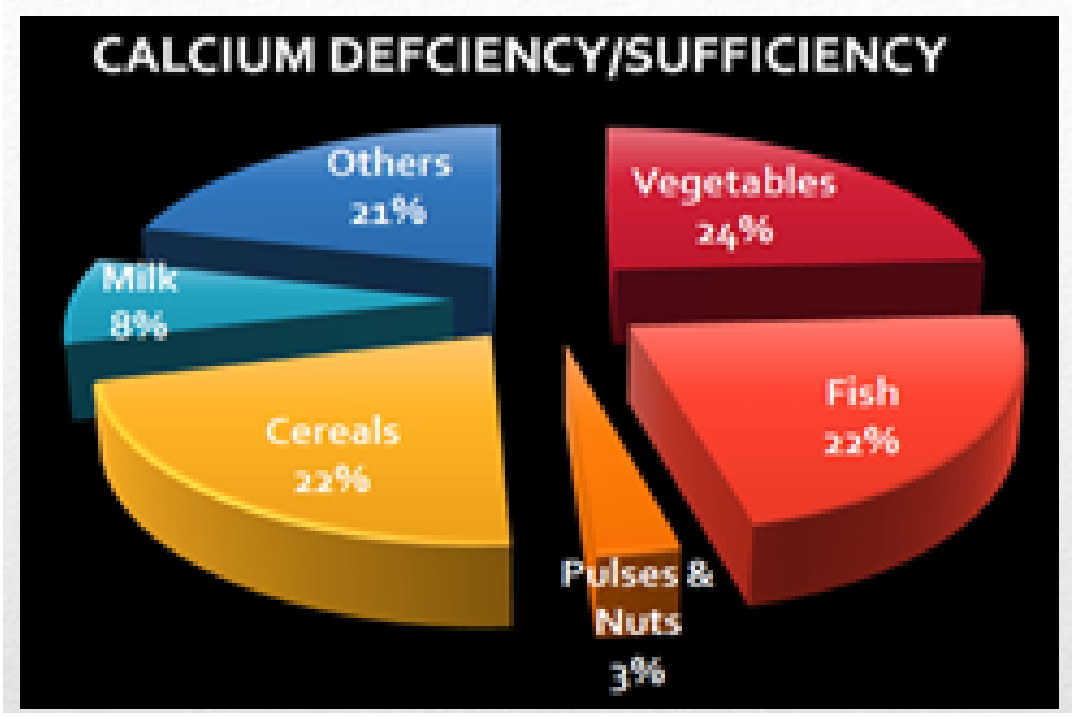

Figure 19. Sources of calcium for the Ganges basin people 


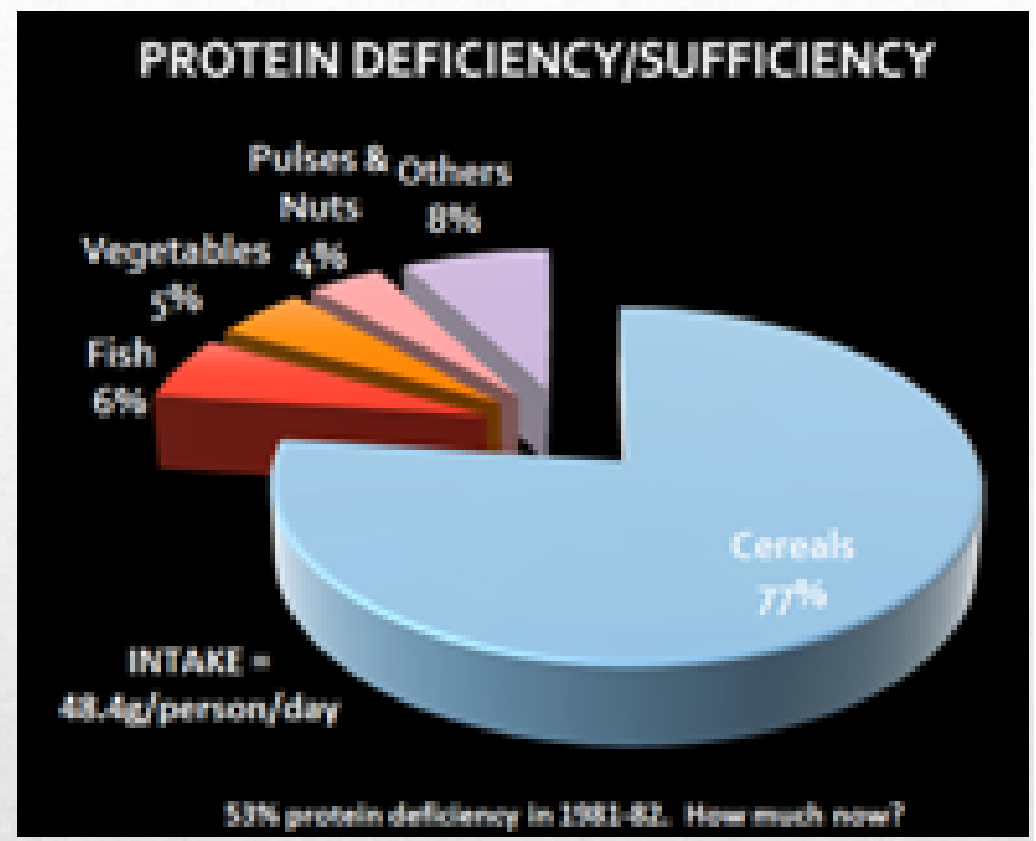

Figure 20. Sources of proteins for the Ganges basin people

The sufficiency and deficiency in nutrition for the basin people found in a survey in the early eighties are shown in Fig. 21. Calcium deficiency was more than $90 \%$ and protein deficiency was more than $50 \%$. Now fish is scarce and population has increased which predict broadening of the gap. It may be mentioned that in the pre-piracy period 277,000 metric tons of fish production dropped to 185,000 metric tons in 1991 .

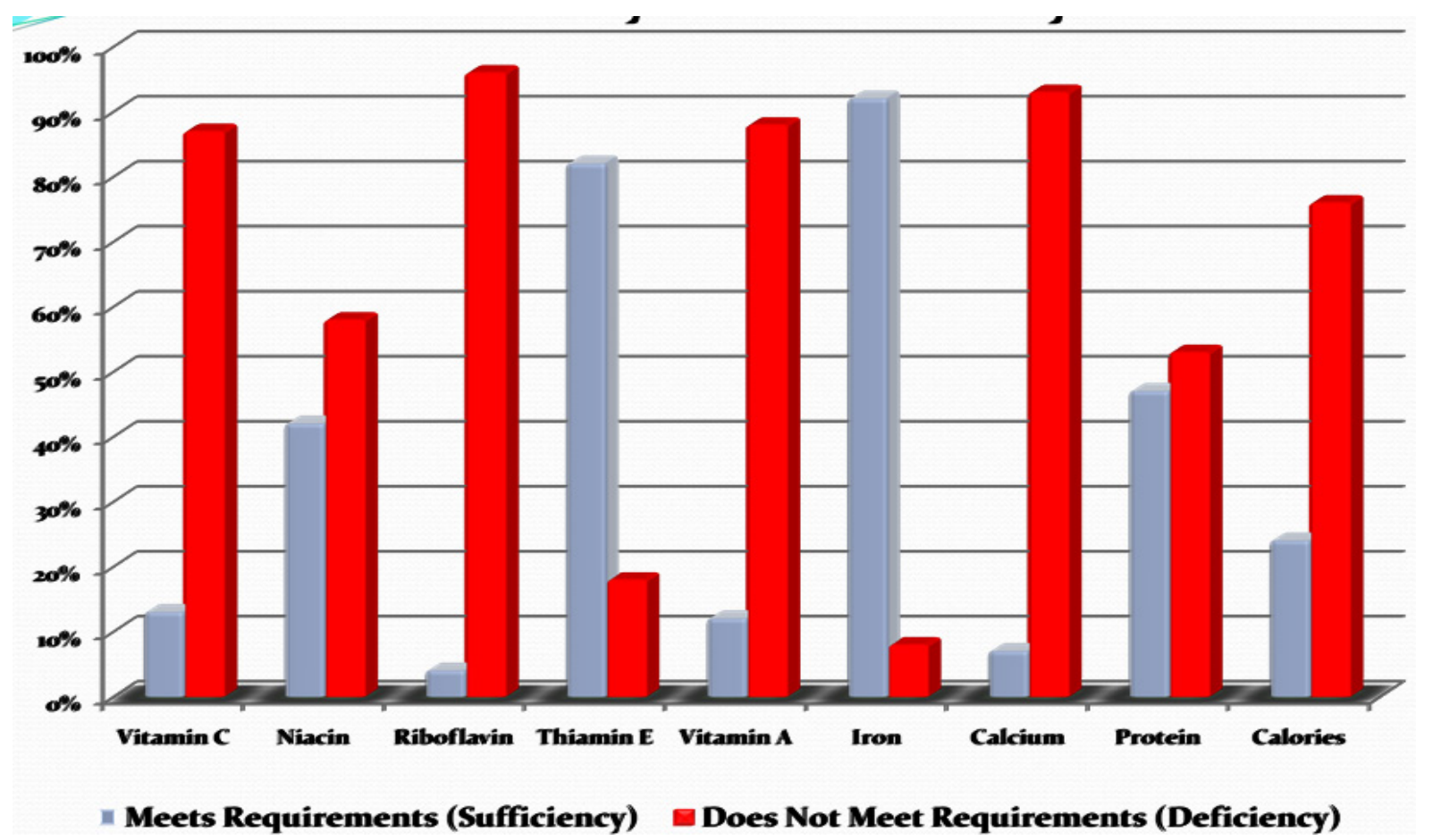

Figure 21. Nutritional sufficiency and deficiency plot of the early eighties

\subsection{Loss of livelihoods}

The depletion of water resources has cost seasonal livelihood loss of a certain percentage of people in every rural unit and the annual livelihood loss of professional fishermen communities in the basin area. In a survey of the mid-nineties of the last 
century, it was found that the number of fishermen, pottermen, boatmakers, and fishing gear makers dropped from 6.0, 4.0, 0.4 and 5.4 to $0.5,0.5,0.08$, and $1.3 \%$ of the rural population. A population of 150 fishermen would make 350 fishing nets of 20 kinds for catching 15 to 20 varieties of fishes. Fig. 22 shows the condition of an unemployed fishermen. Fishermen that spent almost the whole year on water in the pre-piracy period did not get water to take shower in the post-piracy period. This was disclosed to the author by a fisherman's wife during a visit to the community. Further, the community proposed to the author to take all of their landed properties in lieu of their free passage to the water pirate's country. They had untold sufferings. There has been a discontinuity in the learning of fishing technology and fishing gear making. These are home-grown techniques that fishermen kept thriving for generations. Water piracy made an obliteration of this technique in this part of the riverine Bangladesh.

In aggregate, in the Ganges basin the livelihood of 200,000 people were directly or indirectly dependent on fish resources.

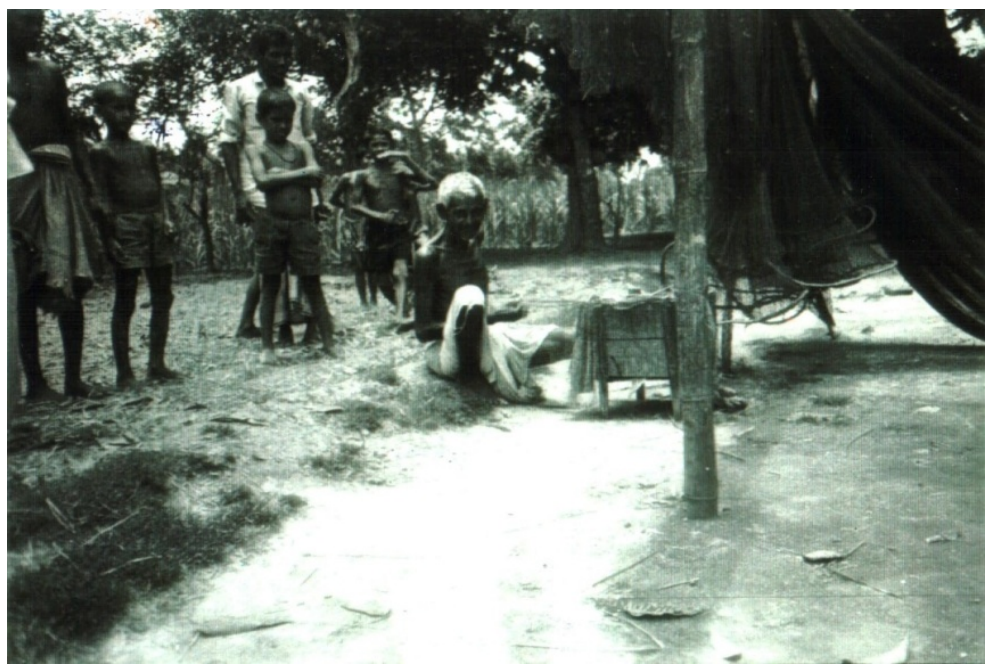

Figure 22. Loss of livelihoods in the Musa Khan basin. Generations-old homegrown profession failed to earn a livelihood in the post-piracy period.

\subsubsection{Loss of Inland Waterways}

Rivers had been the chief mean of transportation in the riverine Bangladesh. Transportation in navigable routes is 5 to 6 times cheaper than the land transportation. The British colonial power did not feel the importance of roads and highway transportations and they did not develop it. After their 200 years of rule plus three-quarters of century of post-rule, the British-made neel cottage still stand by the side of the obliterated distributary Hoja River (due to the upstream piracy of water), the distributary of the Musa Khan. Neel was a kind of plant from which the colonial power used to extract the blue dye. In the native language of Bangladesh, neel means blue. Fig. 23 shows the photograph of the old neel extraction dome for retting the plant. The Hoja River would be used for the brisk neel business in this part of the Ganges basin. Fig. 24 shows a part of the Musa Khan River that would connect the deep southern Bangladesh near the Bay of Bengal to this deep northern part. These days crowded land transportation causes fatal accidents. There were a total of 4,000 km inland major navigable routes in 1970. In the mid-nineties, it reduced to $950 \mathrm{~km}$. The lost waterways measure $3050 \mathrm{~km}$. These routes includes Godagari to Goalando in the Ganges/Padma, Rohonpur to Godagari in the Mahananda, Charghat to Bera in the Baral, Pabna to Bera in the Ichamati, Bardia to Khulna in the Bhairab, deep south from Barisal to Jhalmalia in Rajshahi in the Musa Khan (both in the dry and wet seasons), Benogati to Gajirhat in the Chitra, Magura to Bardia in the nabaganga, Manikdah to Khulna in the Ankabanka. These routes may be located in Fig. 3 above. 


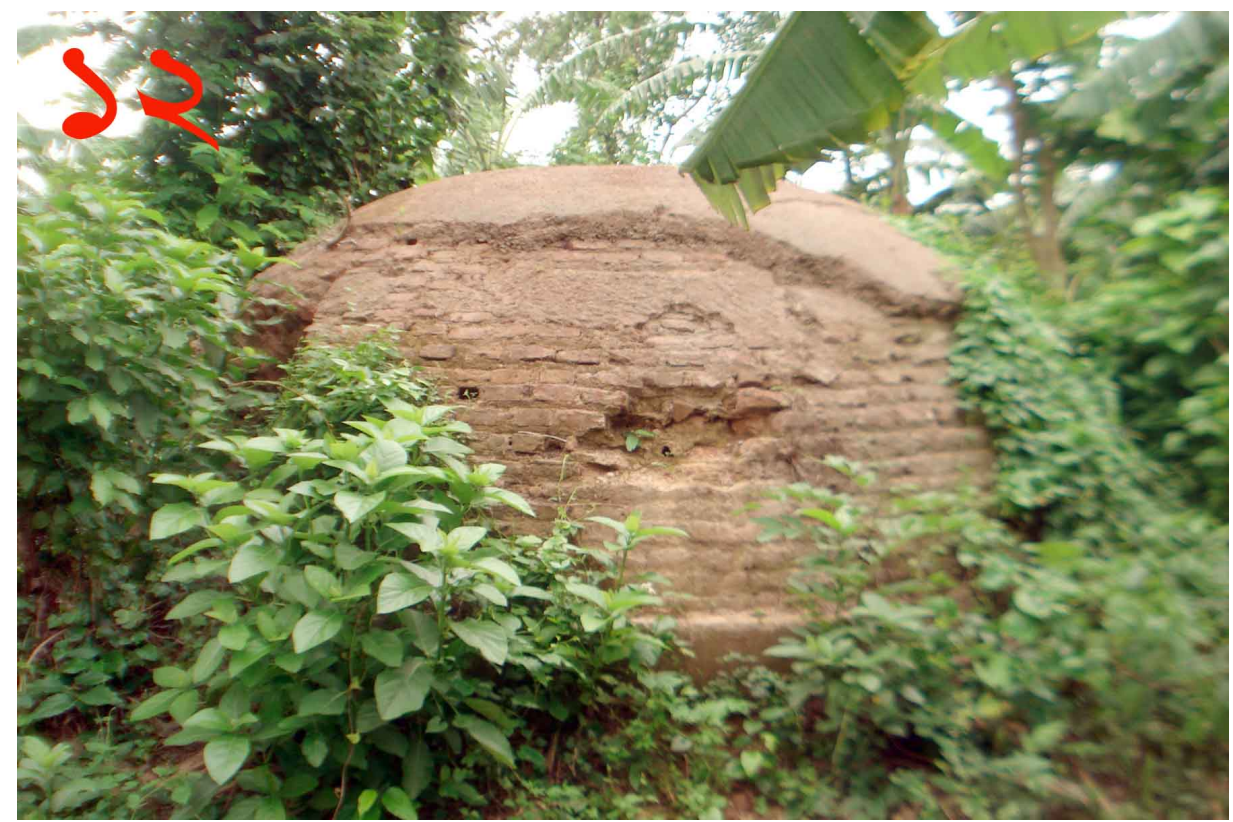

Figure 23. This dome-structure located in Pike Para village was used by the British colonialist for retting neel plants, a process used in the extraction of the blue dye.

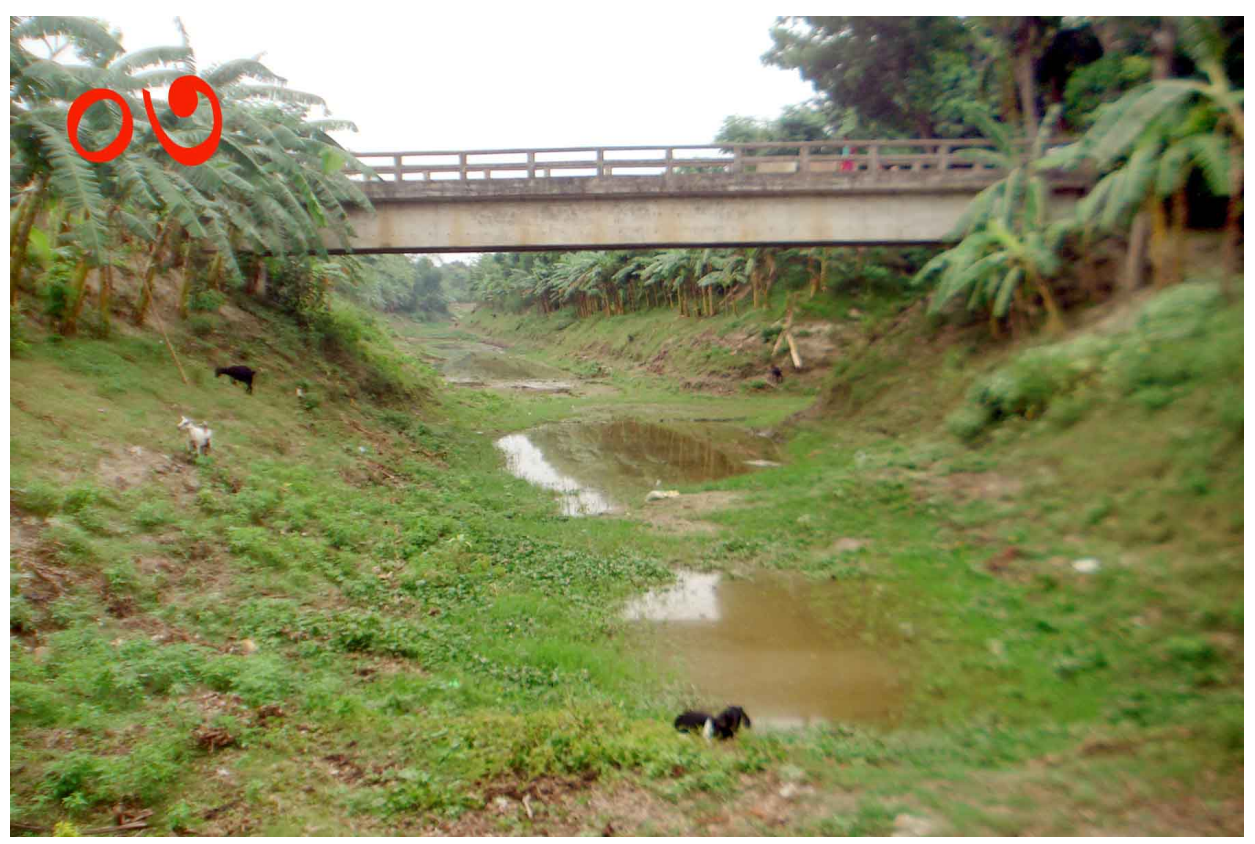

Figure 24. This river way through Joyrampur village would connect the farthest southern part like Barisal with this very interior northern part of Rajshahi

\subsubsection{Generation of Extreme Climate}

With the Ganges/Padma discharge down from $1932 \pm 228 \mathrm{cu} \mathrm{m} / \mathrm{s}$ to $769.5 \pm 284.5 \mathrm{cu} \mathrm{m} / \mathrm{s}$, dead primary, secondary, and tertiary distributaries, floodplains and ponds being some year dry and some year having $50 \%$ less water than the pre-piracy period, and groundwater sinking at $0.50 \mathrm{~m} / \mathrm{s}$ or more per year, the weather has become extreme. In the summer, the maximum temperature rose from 98.6 to 109.5 degree Fahrenheit, the most often-felt temperature rose from 87.8 to 90.0 degree Fahrenheit, the average temperature went up from 85.5 to 87.4 degree Fahrenheit, and the heating degree days increased by a factor of 1.33. On the contrary, in the winter, the minimum temperature has dropped from 46.6 to 41.0 degree Fahrenheit, the most-often felt temperature went down from 78.8 to 77.0 degree Fahrenheit, the average temperature decreased from 68.5 to 67.6 degree Fahrenheit, and the cooling degree days increased by a factor of 1.44 (Fig. 25). Because of losing the water resources which are also heat retainers, 70,000 million billion calories of heat warm up the environment in the summer and cool the environment in the winter in the Ganges basin which is just 0ne-third of Bangladesh. The frequency of the highest relative humidity increased from 1635 to 2957 , the maximum humidity increased from $90.21 \%$ to $92.54 \%$, the minimum 
humidity dropped from $55.20 \%$ to $52.90 \%$, and the most often occurring summer time relative humidity remained unchanged, but the winter time one increased from $65 \%$ to $70 \%$. These features were observed during the period of 1971 through 1989 which covers both the pre-piracy and the beginning years of the post-piracy period.
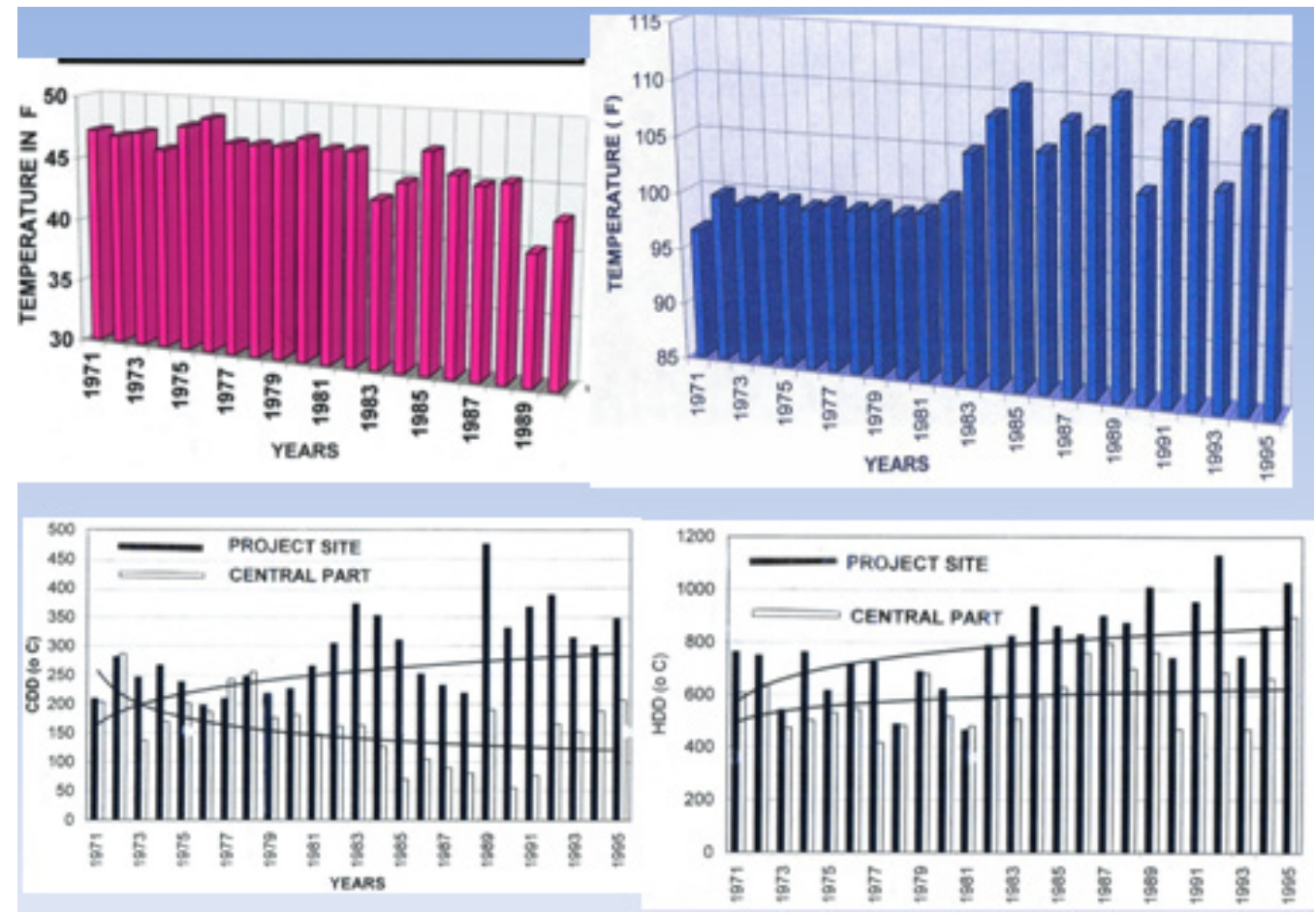

Figure 25. Dropping of the winter time lowest temperature (top left inset); rising of the summertime highest temperature (top right inset); the Ganges basin rising CDD is compared to the unaffected central Bangladesh dropping CDD (bottom left inset); the Ganges basin relatively rapidly increasing HDD is compared to the unaffected central Banglasdesh weakly rising or almost unchanged HDD (bottom right inset).

The frequency of light rainfall or no rainfall increased but that of heavy rainfall $(\geq 100 \mathrm{~mm}$ ) decreased by $50 \%$. The drought of 2010 made all the surface water resources dry. Fig. 26 shows the change in the rainfall pattern in the Ganges basin region which is the Rajshahi region. In a group, the rainfall bars appear in this order - Rajshahi, Rangpur, Dinajpur, and Dhaka (the central part). Both the highest and the lowest rainfalls are decreasing.

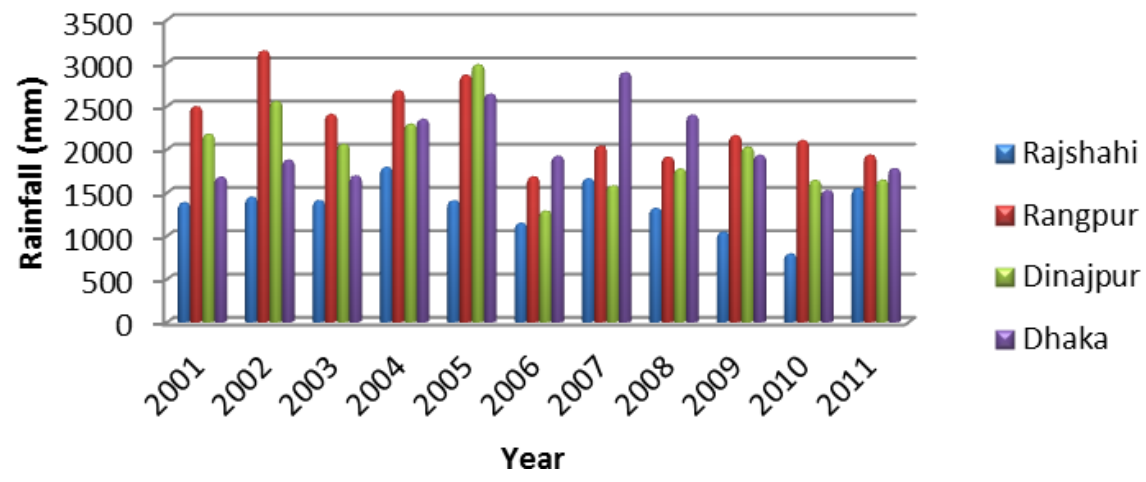

Figure 26. The Ganges basin (Rajshahi) has the lowest rainfall and varies greatly from year to year. The lowest rainfall of 2010 rendered even the deepest surface water bodies like ponds dry.

\subsubsection{Depleting Groundwater}

As said above, the groundwater has been sinking down at an alarming rate because of people's $100 \%$ dependence on it for domestic, agricultural, and industrial uses. Fig. 27 shows depleting groundwater table, the last resort of the country. Fig. 28 shows the gradual spreading out of the depleting groundwater during. The vertical axis shows the increasing number of the basic local government units called unions with the increasing number of years of water piracy. Fig. 29 shows the gradually declining services by the ordinary hand tubewells and the increasing services by the tara pumps. Fig. 30 shows the scarcity of 
potable water for which housewives and others have qued near the only pump serving the community although nearly each family has an ordinary hand tubewell for potable groundwater extraction. It is a shameful scene for the riverine Ganges basin! Fig. 31 shows a tara pump (left side inser) and an ordinary hand tubewell (right side inset)

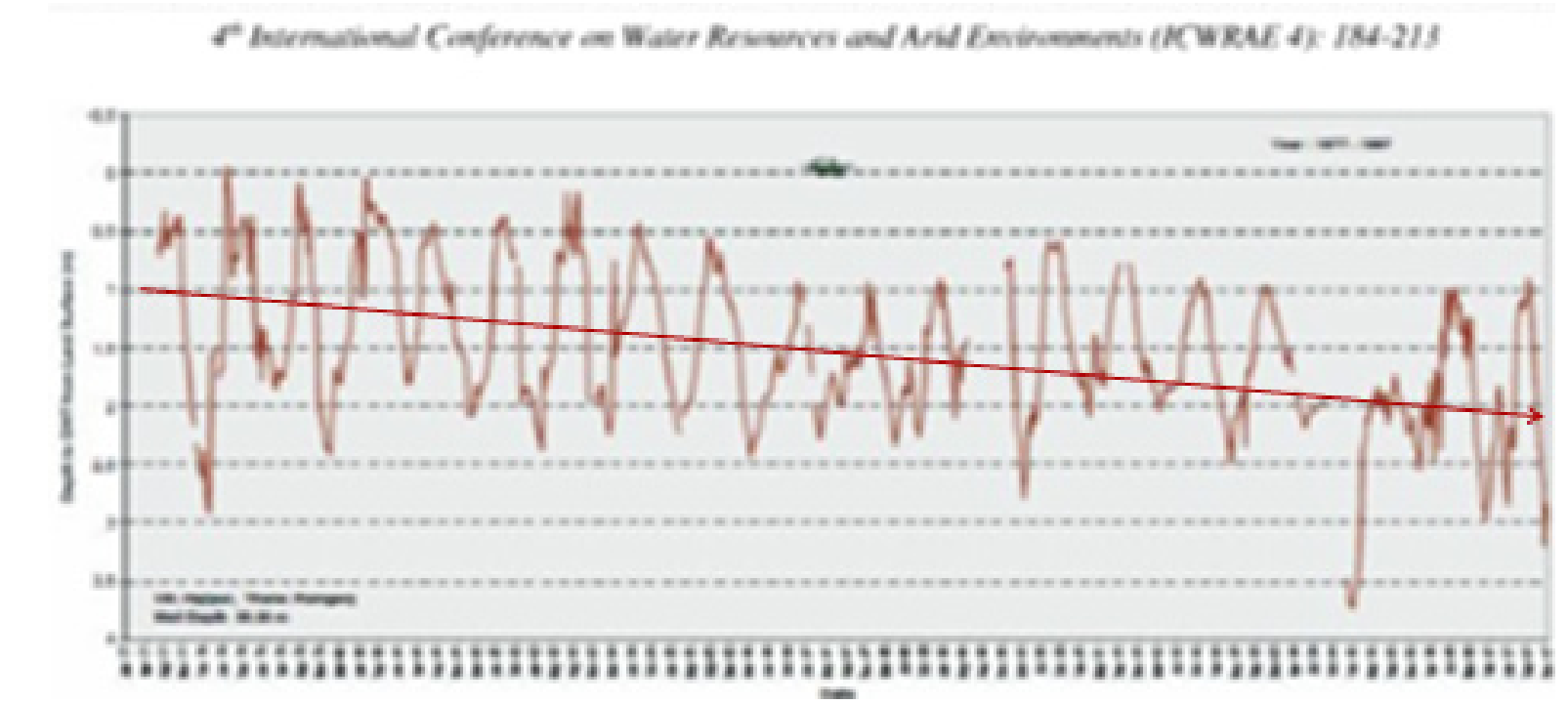

Figure 27. Rapidly sinking groundwater table (referenced in Husain et al, 2010).

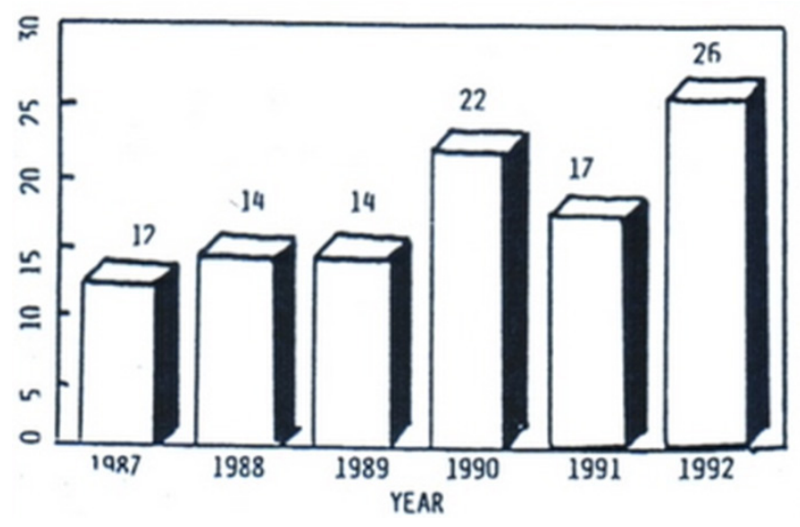

Figure 28. A picture of how more and more unions (along the vertical axis) comprising of about 10 rural units and covering about $40 \mathrm{sq} \mathrm{km}$ falling under the regions of sinking groundwater

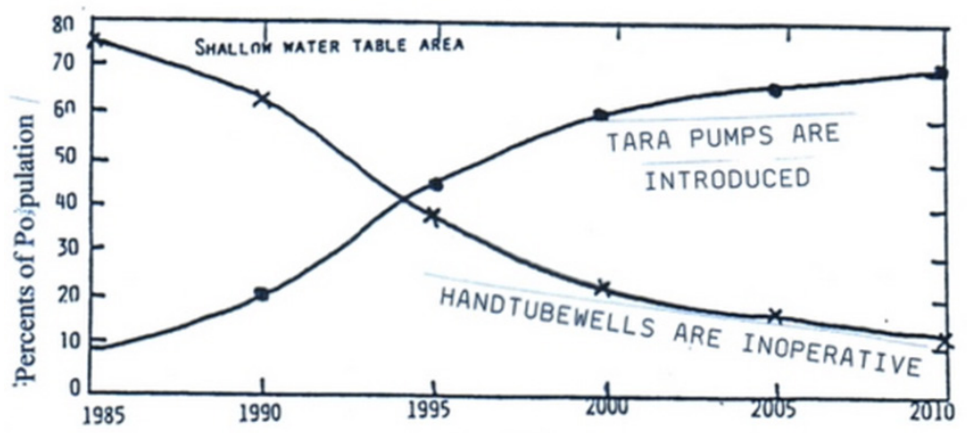

Figure 29. Illustration of how different population communities lost the shallow water in 1985-2010. These days tubewells are set to deeper than $140 \mathrm{ft}$, In water abundant days about $30 \mathrm{ft}$ would be enough for extracting water throughout the year. 


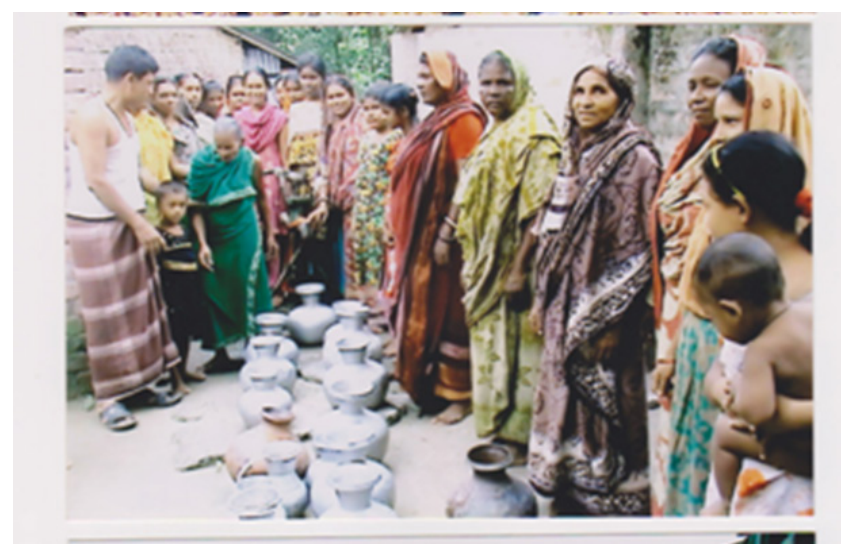

Figure 30. Waiting in a que for potable water collection, although, almost every household has a tubewell for groundwater extraction (Courtesy of Dr. Samad)
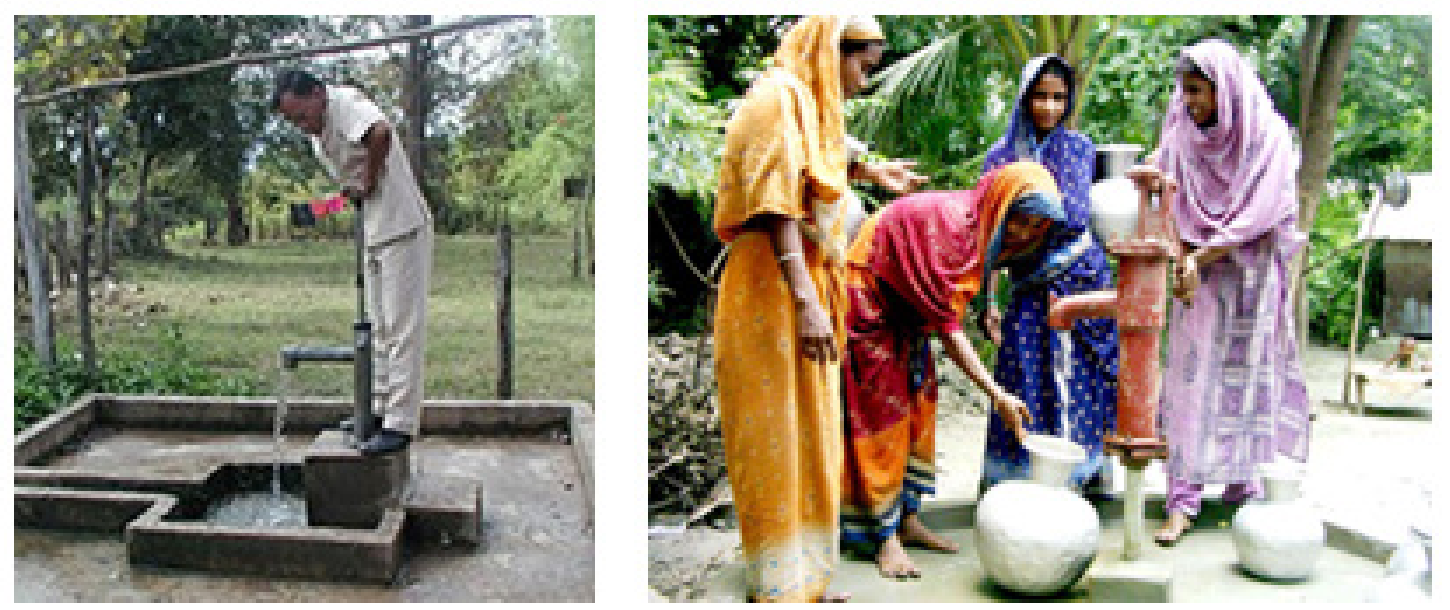

Figure 31. Left side inset shows the tara pump (http://akvopedia.org/wiki/Tara_pump) Right side inset shows groundwater extraction using ordinary hand

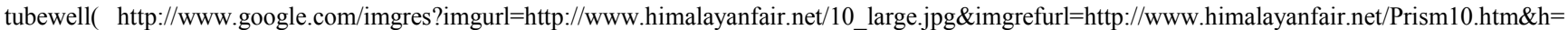
$525 \& \mathrm{w}=700 \& \mathrm{sz}=150 \&$ tbnid $=\mathrm{QUX} 6 \mathrm{ah} 4 \mathrm{YW} 3 \mathrm{v} \_\mathrm{TM}: \& \mathrm{tbnh}=90 \& \mathrm{tbnw}=120 \& z 00 \mathrm{~m}=1 \& u s g=$ T6wM\&sa $=$ X\&ei $=$ WzV1UoD5BeG72AWOzICQCQ\&ved=0CDkQ9QEwBA)

\subsubsection{World's Worst Man-made Disaster - Arsenic Contamination of Groundwater}

Water piracy-caused sinking ground water has brought the world's worst and ever man-made disaster in the Ganges basin. The contamination of groundwater has affected about 75 million people in the Ganges basin. Fig. 32 shows some of the tubewells located on the banks of the Musa Khan River that extracts arsenic-contaminated groundwater. Fig. 33 shows some of the patients of arsenocosis. The sores on the body create unbearable burning. It is very unfortunate for the people of Bangladesh that their government never raise their voice against the injustices done to the people by the Indian upstream water piracy. The degree of arsenic contamination in the groundwater throughout Bangladesh is shown in Fig. 34. A riverine wetland ecosystem as the one in Bangladesh is bound to collapse if $60 \%$ of its founding and sustaining water is pirated. 


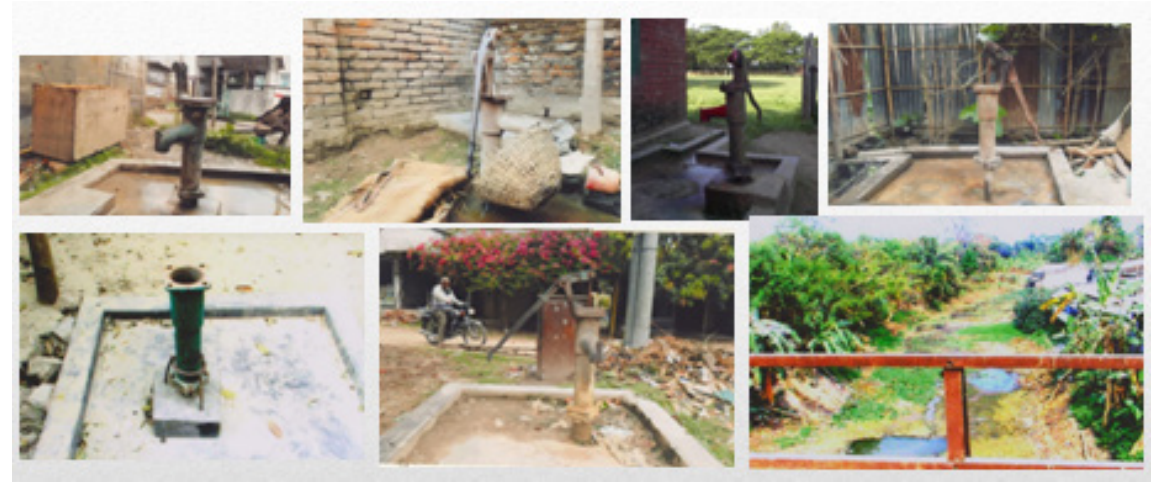

Figure 32. Tubewells by the abandoned river channels extract arsenic with groundwater.

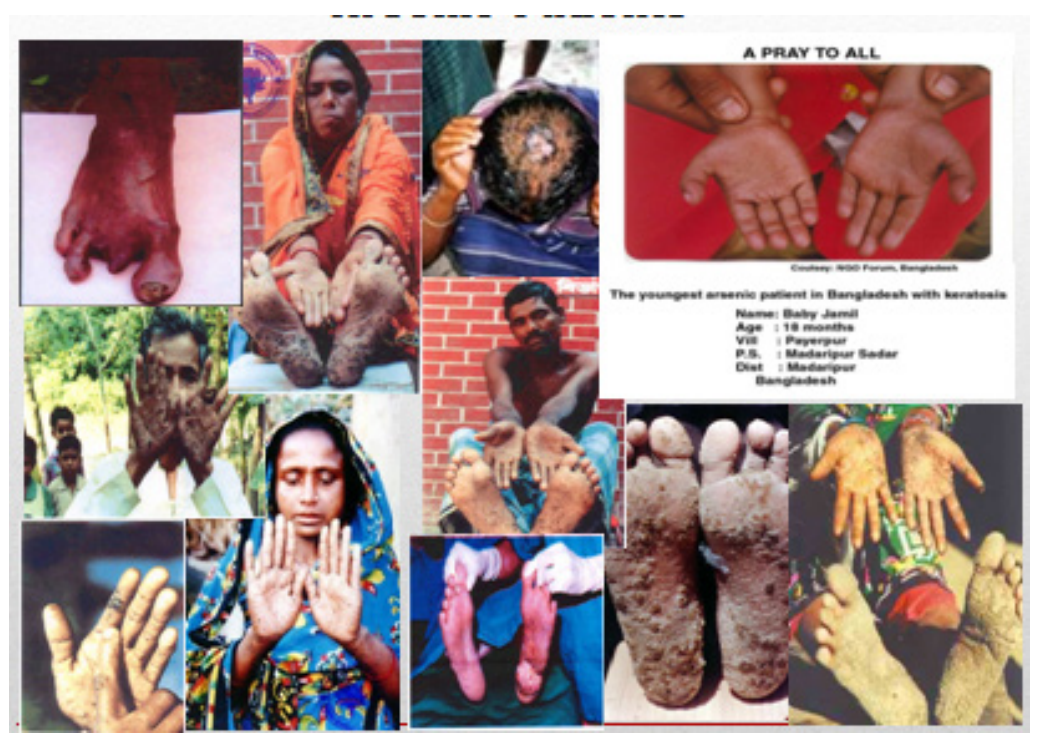

Figure 33. The world's worst curse of upstream water piracy. A 18-month old baby is also shown to have the symptoms of arsenicosis (top right corner).

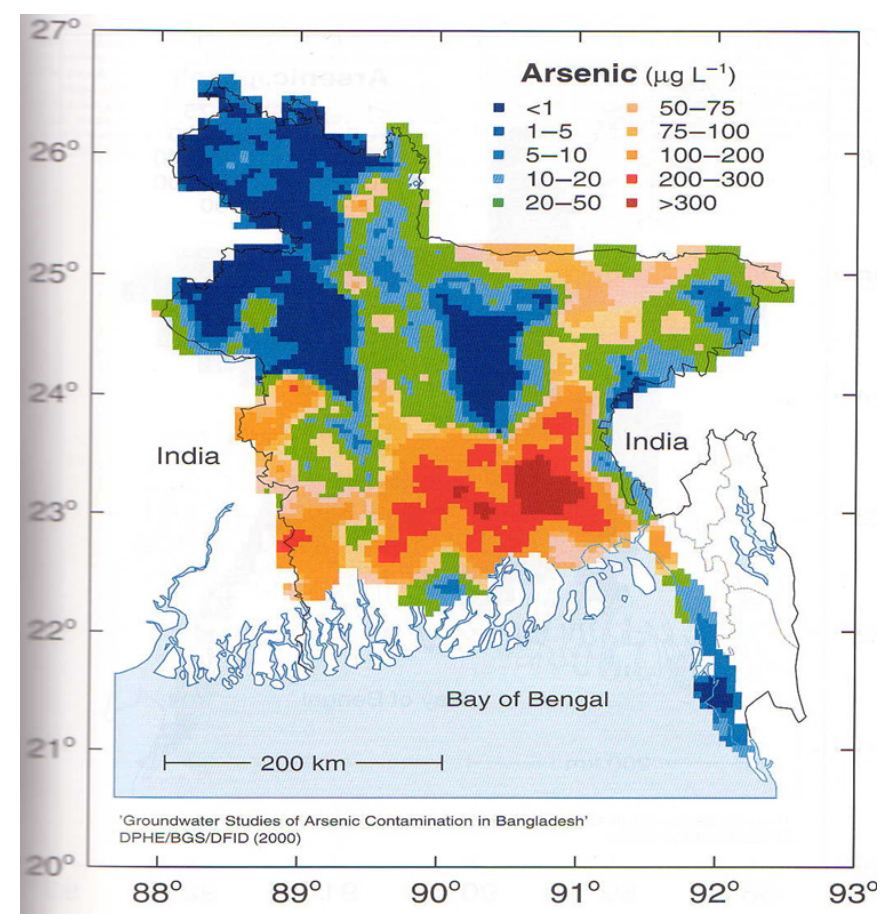

Figure 34. Groundwater arsenic contaminated areas. The Ganges basin part is the worst affected. 
A virgin ecosystem picture of Bangladesh is shown in Fig. 35. These water-nourished components of an ecosystem cannot survive if the elixir is cut short.

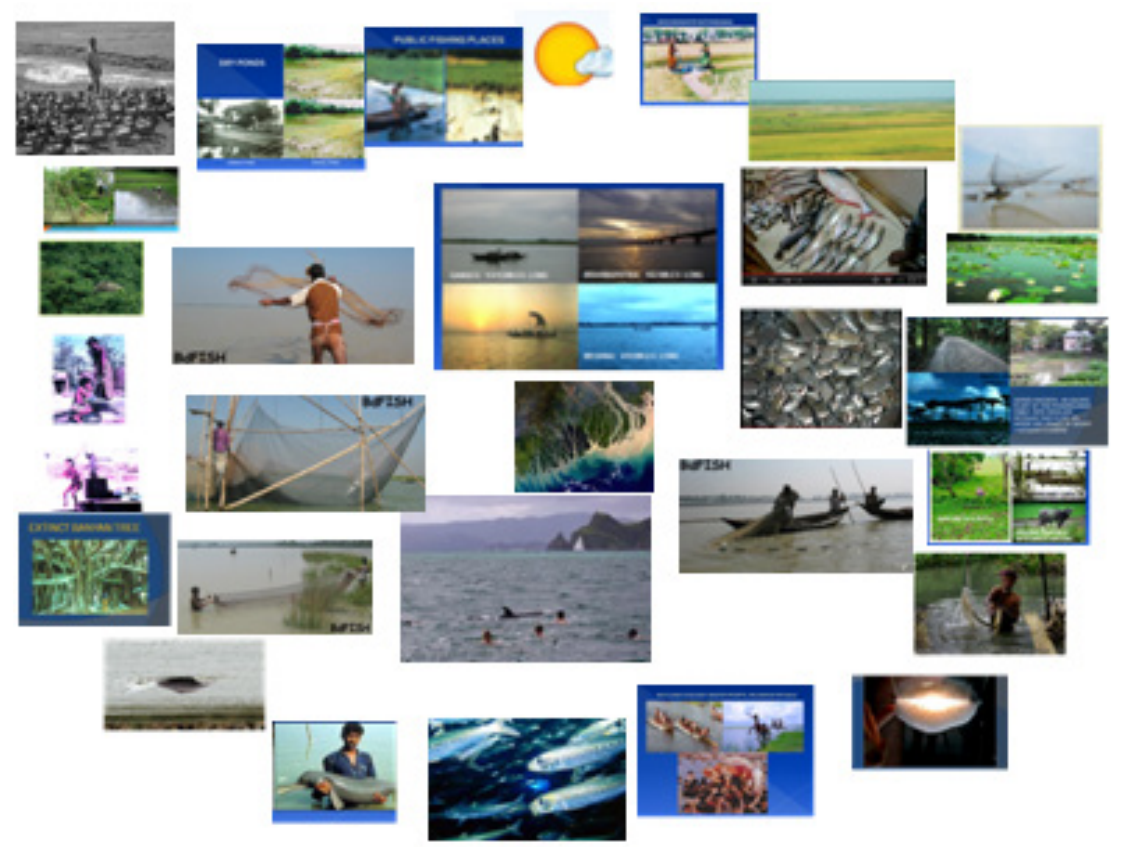

Figure 35. Glimpses of the riverine ecosystem of Bangladesh (Courtesy of the picture suppliers)

\subsubsection{Inland Advancement of the Saline Water Front}

Coastal rivers total $24,000 \mathrm{~km}$ over an area of $9,380 \mathrm{sq} \mathrm{km}$ (bottom part of Fig. 3). About $66 \%$ of coastal land is saline. Salinity covered 833,000 ha in 1973 , and $1,056,000$ ha in $2009.5,000$ millimho engulfed 7,000-12, 000 sq miles , and 20,000 millimhos engulfed $5000-8000$ sq miles. Salinity attacked 45 million trees and plants in 2,200-sq miles wide Sundarbans in the nineties. Salinity has deceased the net cropped areas. Fig. 36 shows the salinity affected areas. Salinity caused scarcity of drinking water and declination in industrial production. Saline water causes health problem in pregnant women, and kidney diseases, and rheumatism in human, and affect milk productivity and reproductive health in cattle. Salinity affects growths of forest species. The Gangetic dolphins lost inland freshwater range. They cannot tolerate the coastal saline water. A victim dolphin is shown in Fig. 37.

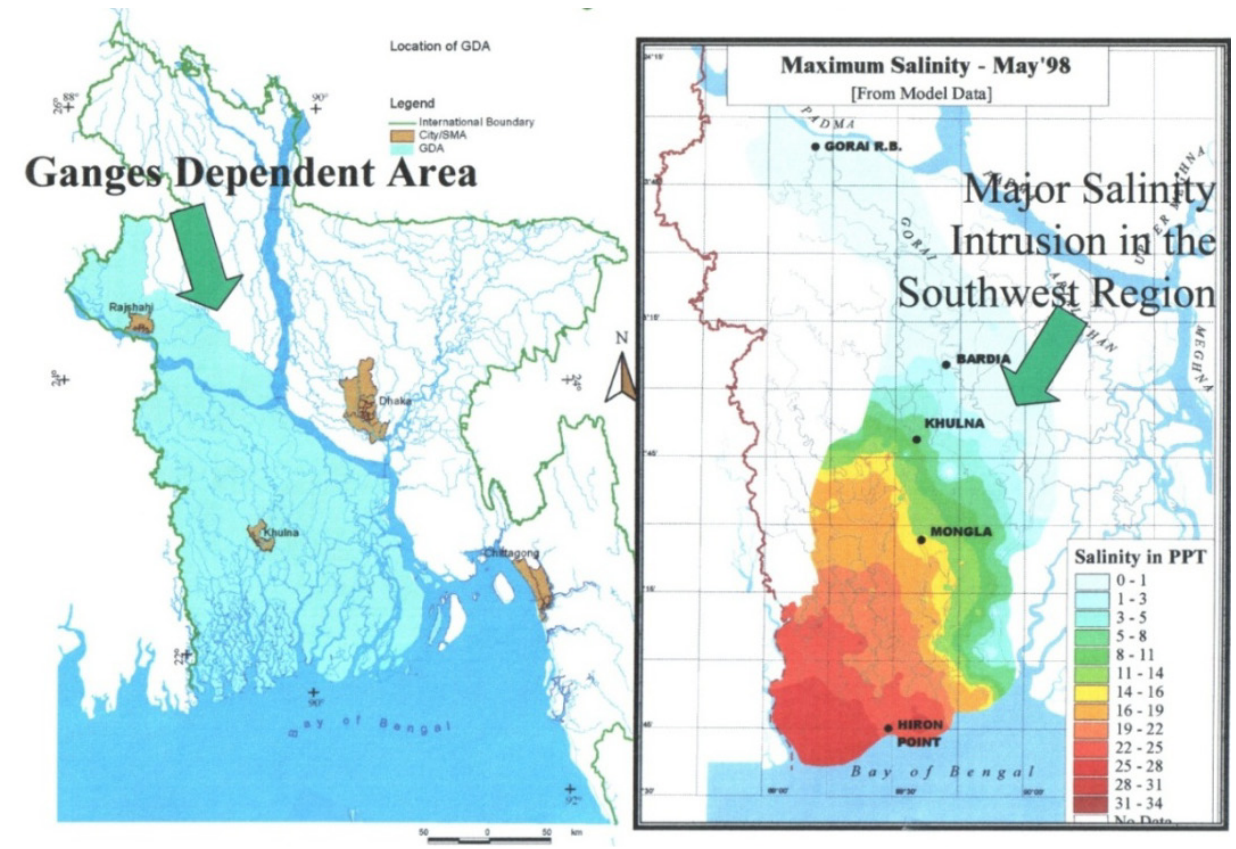

Figure 36. Inland advancement of the salinity front, one of the curses of water piracy (Courtesy of Hossain et al., 2003). 


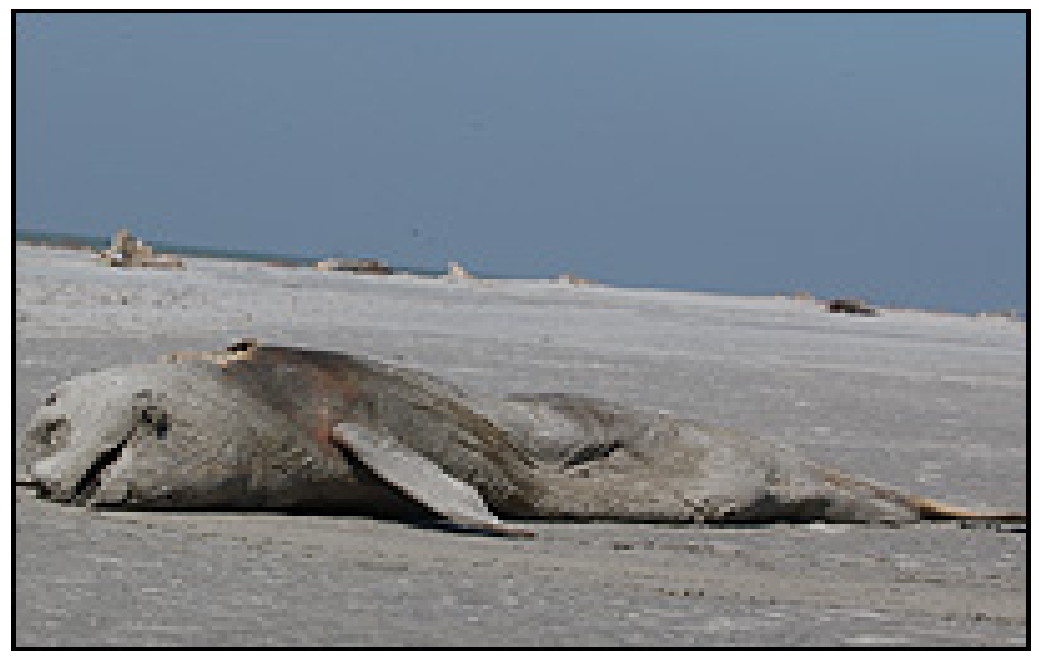

Figure 37. Victims of inland salinity intrusion caused by the upstream water piracy.

http://news.bbc.co.uk/2/hi/asia-pacific/4367135.stm; http://news.bbc.co.uk/2/hi/south_asia/3495989.stm; http://news.bbc.co.uk/2/hi/south_asia/7192200.stm

\subsubsection{Erosion of the Coast}

During 1976-1990, the entire coast lost $50 \mathrm{sq} \mathrm{km}$ (SPARSO). Bhola lost $280.70 \mathrm{sq} \mathrm{km}$, Hatiya $77.58 \mathrm{sq} \mathrm{km}$, Sandwip $110.75 \mathrm{sq} \mathrm{km}$, Monpura $78.45 \mathrm{sq} \mathrm{km}$, and the Sundarbans $297.63 \mathrm{sq} \mathrm{km}$. Out of 794 million tons of the Ganges sediment, the Indian Hooghly coast receives 361 million tons, and Bangladesh just 40 million tons. This is very insufficient to resist the sea's natural tendency to erode the coast line. Indian Ganges floodplain receives 65 million tons and Bangladesh floodplain 328 million tons. This is enough for a quick silting of the Bangladeshi water bodies.
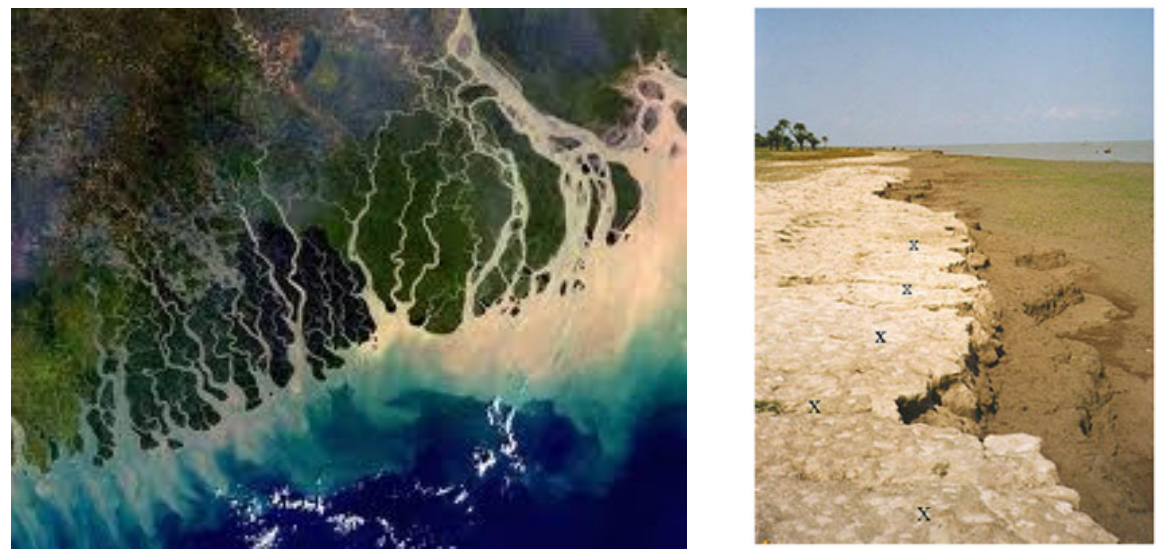

Figure 38. Coastal erosion

\subsubsection{Piracy from Other International Rivers}

There are more than 25 rivers that include some major ones from which India unilaterally pirates water. All of these rivers are marked by red circles in Fig. 2 (Adel, 2001). In about a decade later than the preparation of Fig. 2, more dams and barrages might have been planned and built, a work that does not disclose to her counterpart.

\subsubsection{The Tista Barrage}

India built the Tista Barrage at Gazaldoba in the district of Jalpaiguri with which she diverts $54 \mathrm{~m}^{3} / \mathrm{s}$ of water from the Tista into the Mahananda (Fig. 1) in the dry season. No treaty has been signed on sharing the Tista flow. In 1983, a memorandum of understanding reached between the two countries in which Bangladesh was to get $36 \%$, India $39 \%$, and $25 \%$ for reserve. However, no settlement has yet reached. Bangladesh raised objections to pirating the Tista flow to the Mahananda from the beginning. 

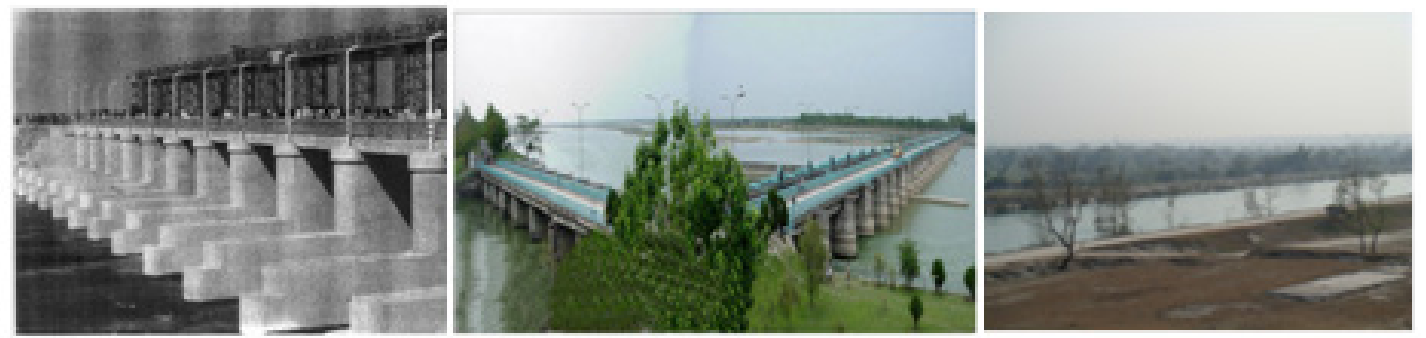

Figure 39. The Indian Tista Barrage for pirating water at a rate of $42.5 \mathrm{cu} \mathrm{m} / \mathrm{s}$ in the dry season (Courtesy of Wikipedia;

http://www.google.com/search?q=Tista+Barrage\&rls=com.microsoft:en-us:IE-Address\&ie=UTF-8\&oe=UTF-8\&sourceid=ie7\&rlz=1I7DKUS_en

The Tista Project ( Fig. 39), one of the main irrigation projects both in West Bengal and eastern India, is used for irrigation 922,000 ha land spread out in the six districts of West Bengal, production of $67.50 \mathrm{MWt}$ of electricity from three water falls that let fall water into the Mahananda Main Canal, setup of navigable routes, and flood control. The pirate ensures protections in all sectors with the Tista water. She is indifferent to the downstream 's need accepting the Tista River as her paternal property. The pirate's central authority the Indian government blames the West Bengal State government of not allowing any water sharing treaty which is nothing but a trick for unilateral water piracy.

The principal parts are the Tista Barrage at Udlabari, one pickup barrage on the Mahananda River at Fullbari of Rajganj Block in the Jalpaiguri District of West Bengal, and another pickup barrage on the Dauk River at Chapra Balk of North Dinajpur District. There are 25.64-km long the Tista-Mahananda Link Canal, 32.33-km long main Mahananda Canal, 80.62-km long Dauk Nagar Main Canal, and 30.50-km long Nagar Tangon Main Canal. Including the aqueduct at river crossings, the twelve cross drainage infrastructure are Karala, Neem, Korotoa, Sohu, Jorapani, Babang, Mahananda, Nagar, Luna, Kanchan, Kulik, and Kharala (http://wbiwd.gov.in/irrigation_sector/major/teesta.htm)

\subsubsection{The Mahananda Dams}

The Mahanda (Fig. 3 for location)) is the only tributary of the Ganges in Bangladesh. India constructed two dams upon the Mahananda River - one at $3 \mathrm{~km}$ and the other at $32 \mathrm{~km}$ upstream (at Khodaimaree) of Tentulia. A 42-km long canal from the dam site links the Teesta and the Mahananda rivers. Water is pirated from the Mahananda during the dry season resulting in a weakened downstream flow ( Fig. 40) that affects Bangladesh's northern districts of Rangpur and Dinajpur in agriculture, industry, and the ecosystem.
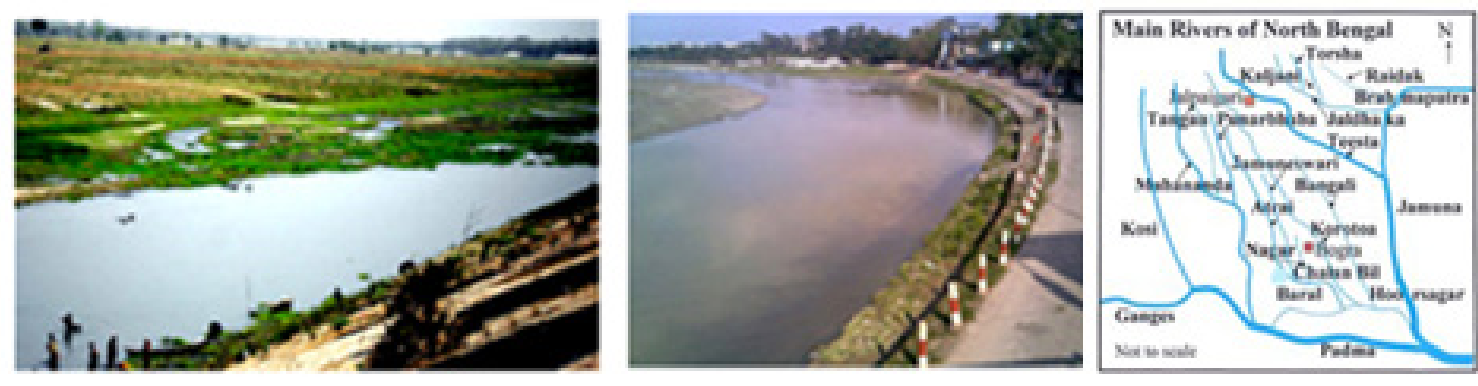

Figure 40. The Mahananda River in Bangladesh (Courtesy of Amar Desh), the Mahananda in India, the the Tista basin above the Ganges/Padma basin

http://www.google.com/search?q=Mahananda+River\&rls=com.microsoft:en-us:IE-Address\&ie=UTF-8\&oe=UTF-8\&sourceid=ie7\&rlz=1I7DKUS_en; http://en.wikipedia.org/wiki/Torsa_River).

The Mahananda dams controls discharges in 15 rivers in Bangladesh. These are the Mahananda, the Korotoa, the Tista, the Bhaluka, the Ranchandi, the Talma, the Ghoramara, the Buritista, the Versa, the Chilak, the Balam, the Pisla, the Dahuk, the Chawai, and the Kurum. The dams have taken away the livelihoods of many people who would collect pebbles carried down from the Himalayas. The dams control floods in India by suddenly releasing the flood water through Bangladesh that takes a heavy toll of lives and properties.

\subsubsection{Mini-Farakkas}

The other transboundary rivers that face dams and other water diversion constructions are the Ichamati-Kalindi, the Betna-Kodalia, the Bhairab-Kabodak, the Khukshi, the Atrai, the Korotoa, the Talma, the Ghoramara, the Deonai-Jamuneshwari, the Buri Tista, the Sangil, the Dharla, the Jinjiram, the Bhogai, the Piyan, the Kushiyara, the Sonai 
Bardal, the Juri, the Manu, the Dhalai, the Khowai, the Sonai, the Gomti, the Selonia, the Muhuri, and the Feni. The location of these rivers are shown in Fig. 1. Water diversion has affected agriculture, fisheries, and navigation in their basins (Sattar, 1996).

Bhairab is not an active river (Fig. 41). It fed rivers of Jhinaidah and Jessore. It faces a cross dam in Nadia District, and a regulator on Jalangi Rivers. Piracy of Jalangi's water drastically reduces Bhairab's flow. Irrigation in Meherpur and Chuadanga affected.

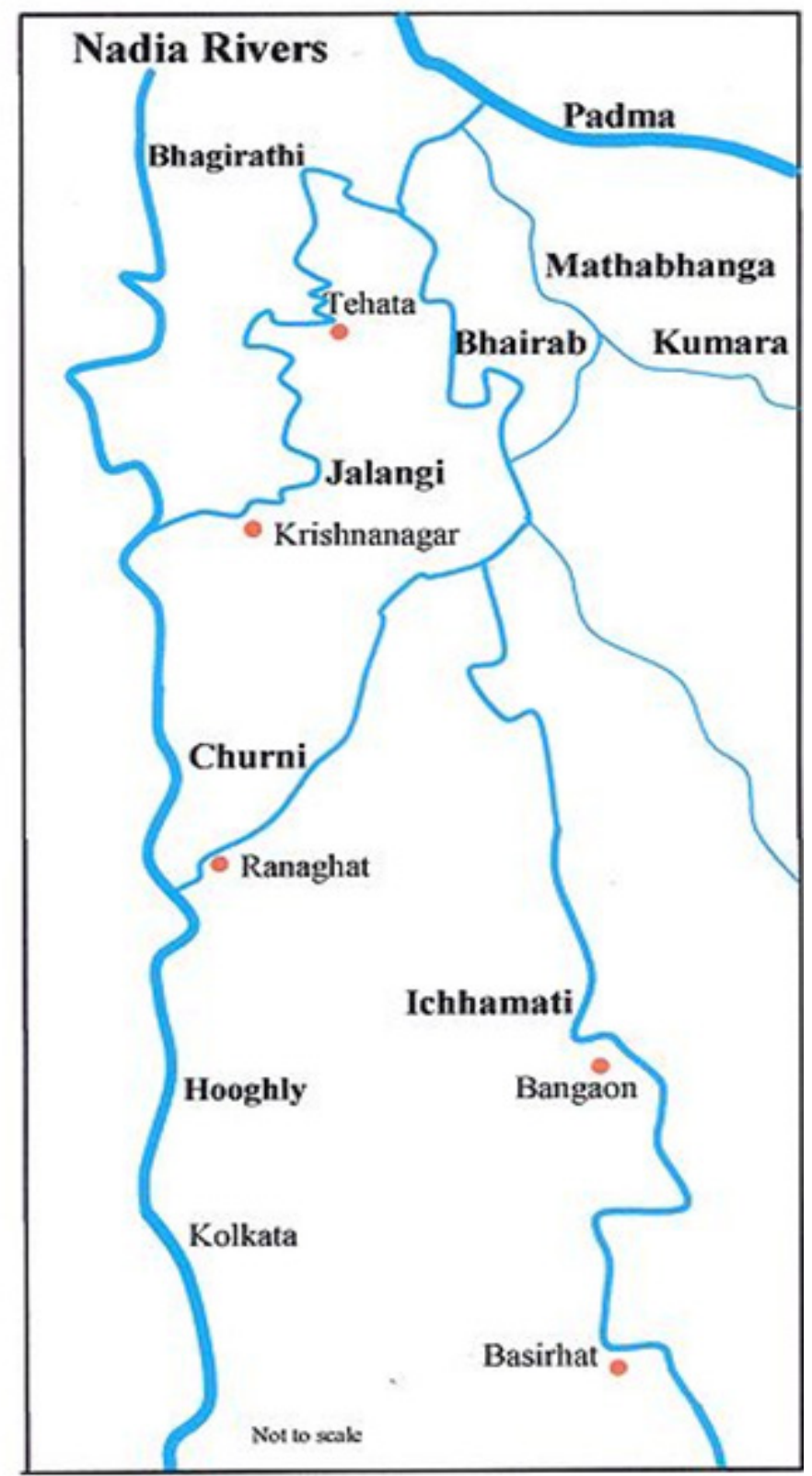

Figure 41. Illustration of the Bhairab would get discharges from the Jalangi River of India. Because of the water piract at Farakka, it does not get water from the Ganges/Padma either.

Kushiara has 33-km long border with India. She built a groin which results in Bangladesh side erosion. India captures the shoals that form in its bed. This way the original Jakiganj town went under Indian control. Eroded upojilas of Jakiganj are Amalsid, Manikpur, Shahisbag, Pinnakandi, AmalnagarGangajal, Dubaria, Bhuiar Mura, Lakshi Bajar, Ujirpur, Barapather, Majheer Gram, Suprakandi, Pearpur, Gadadhar, Lohar Khal. 


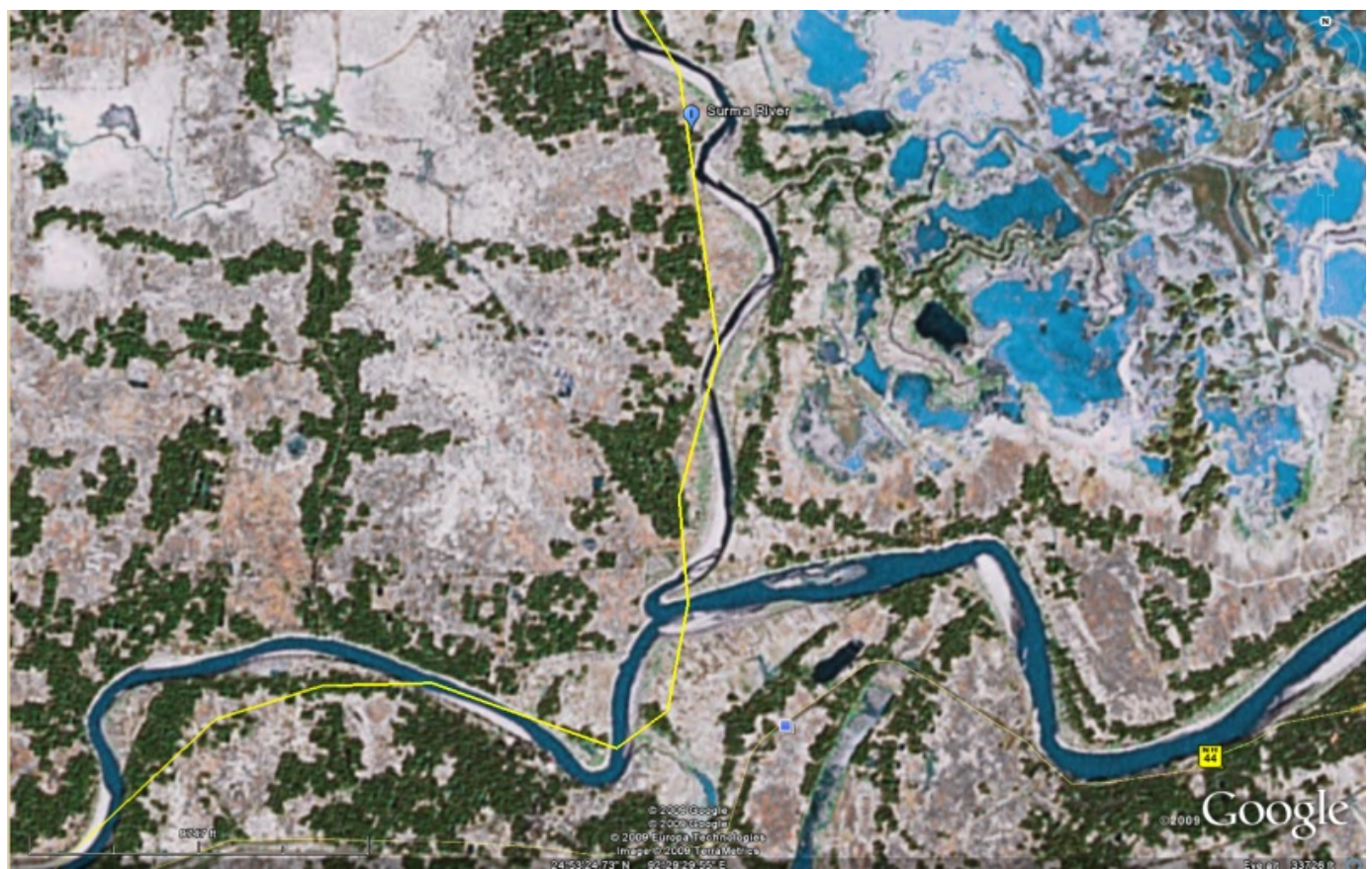

Figure 42. The Surma and the Kushiyara (upward going) Rivers are the branches of the Barak River coming from the left.

India built 9 spars and revetment (sloping structures to absorb water energy) on Muhuri. It erodes the Bangladesh side of the river bank. The erosion creates shoals in the river. Shoals formed by Bangladesh side erosion go under Indian occupation. 111-acres Muhuri's Char was originally within Bangladesh. India occupied 53 acres of that. A battle fought between border forces on 26 June, 1993. Land occupation results from water aggression by groin construction.

\subsubsection{Dead Rivers}

Bangu River has a regulator in Jalpaiguri. Khuksh River faces one barrage in Balurghat. Talma has a barrage at a spot opposite to Bhitorgahr border post of Panchgarh PS. Kadla River faces one dam in Twenty-four Parganas. Madhumati has one in Kakalmari. Karatoa has one barrage at Ambari-Falakataya, currently with Teesta Barrage. Jinjiram has one dam in Meghalay. Gomti has a dam at Mathrani. Sanai Sari Irrigation Project in Comilla district in Bangladesh is affected. Khoi faces two dams in Tripura - at Chakma Ghat and at Kalyanpur. Manu faces a barrage at Kela City, Tripura. Dhalai has a dam in Tripura. Punarbhaba faces a dam at Kamardanga. Pyan/Doukee faces a 43-m long, 9-m wide, and 9-m high groin over Doukee. Putting concrete on India side of Ichamati-Kalindi, makes Bangladesh side erode. It eroded 50 mowjas of Kaliganj, Shayamnagar, Kalaroa, Debhata, and Satkhira. India occupies the shoals formed. Satkhira map has been changing.

The dying rivers due to Indian water piracy are Chatnai, Pakuraj, Mohananda upper, Tirnoi, Ramchandi, Khorka, Kurum, Gobra, Petki, Ghoramara, Korotua, Berang, Bhersa, Tangan, Talma, Dahuk, Chowyia of Panchgarh, Kulik of Thakurgaon, Chepa, Kankra of Dinajpur, Chilky, Manash, Dhaijan, Burikhora, Naotara, Dhum, Buri Tilka of Nilphamari, Ghaghot, Akhira of Rangpur, Fulkumar of
Kurigram, and Baral of upper Rajshahi District, according to the River Research Survey of Bangladesh. These rivers have their distributaries. Riverine ecosystem everywhere is more or less the same. The story of the Musa Khan repeats in all these rivers basin, their distributaries' basins, and sub-distributaries basins.

\section{Projected Dams and River Networking}

\subsection{The Tipaimukh Dam}

India is building the Tipaimukh dam upon the Barak river in Assam, upstream of the Meghna to store $15.9 \times 10^{9}$ cubic meter of water. This Tipaimukh dam is located $200 \mathrm{~km}$ upstream of Amalshit, the point where the Barak River splits into the Surma and the Kushiyara in the states of Manipur/Mizoram in India. The dam will substantially reduce the dry season flow in the Kushiyara and the Surma rivers, the headstreams of the Meghna River (Figs. 1, 2, and 3 ) in north-east Bangladesh.

\subsection{River Networking}

In the meantime, India is planning the grand river networking. In the plan, the main tributaries of the Ganges above Farakka on the right bank are the Upper Ganges, the Jamuna, the Tons, the Karamnasa, the Son, the Punpun, and the Burhi Gandak, and on the left bank are the Ramganga, the Gomati, the Ghaghra, the Gandak, and the Kosi will be interlinked resulting in the drying up of the Ganges downstream in Bangladesh. These tributaries of the Ganges are shown in Fig. 1. 
Under the river networking plan, India will divert 200 to 250 of BCM water from the Brahmaputra, the Teesta and the Meghna basins through about 1,500 km link canals to the Kaveri River of south India. Fig.46 illustrates the grand network of the plan (Courtesy of Hossain et al, 2003). The link canal will extend from Dhubri region of Assam to upstream of Gazal Doba on the Indian Tista of the Indian district of Jalpaiguri. Link canals will be dug from the Sankosh (a tributary of the Brahmaputra) and Manos rivers of Bhutan to add to the Brahmaputra-Tista canal. Later, a 473-km long link canal will connect with the Ganges upstream of the Farakka point. Because of mistrust and environmental problems, Bangladesh government earlier rejected the link canal proposal through Bangladesh (Fig. 1) to divert water from the Brahmaputra upstream of Farakka.

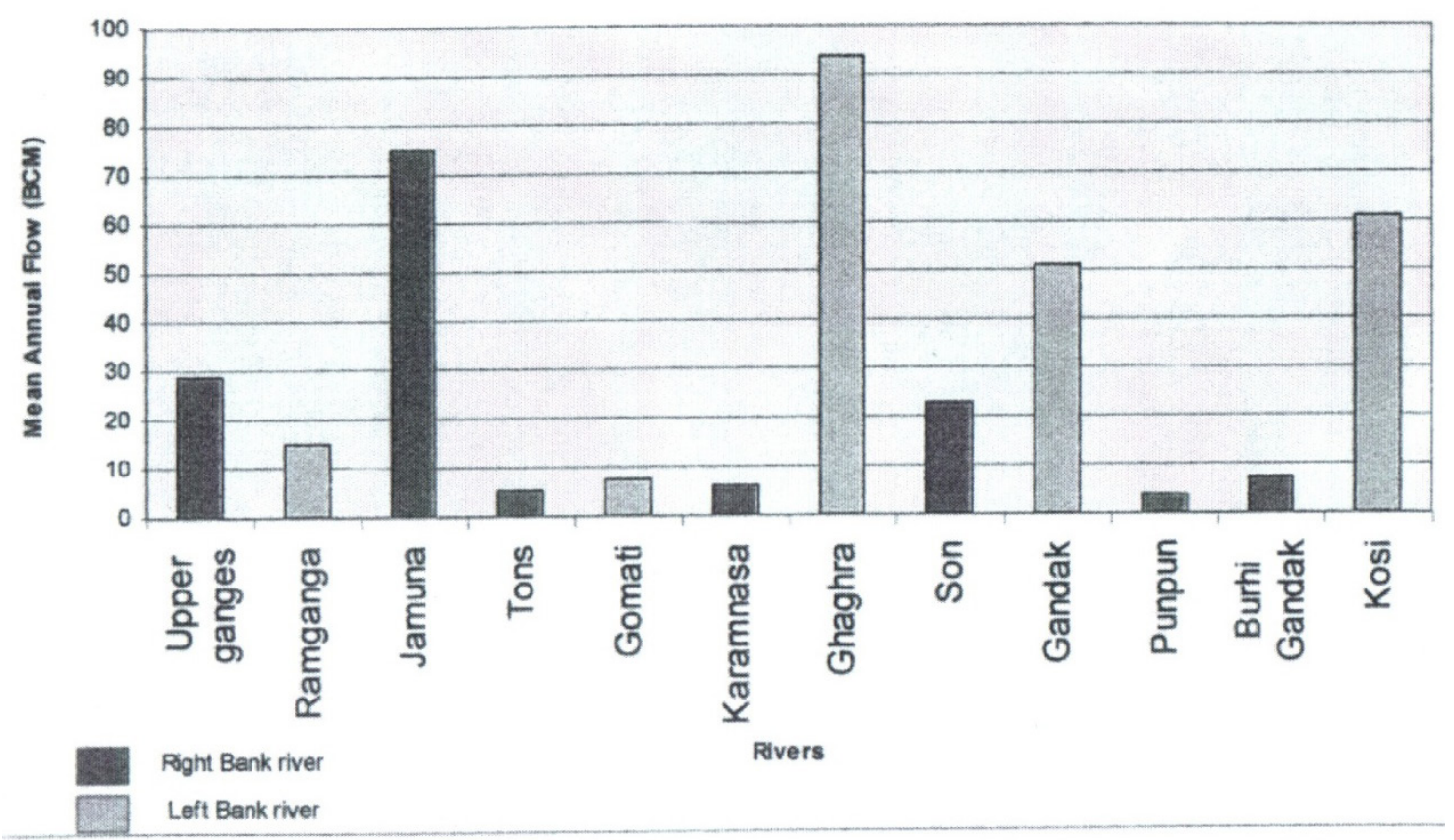

Figure 43. Annual flow volumes of discharge from the main tributaries of the Ganges (Courtesy of Hossain et al., 2003). Their physical locations appear in Fig. 1.

In the second phase of the grand networking of rivers, a link canal will connect the Ganges with the Kaveri of south India through many more small canals linked with the main canal. This artificial control of the river will make the Ganges dry. Also, the rivers - the Tista, the Torsa, the Raydhak, the Jaldhala, the Mahananda, etc. - that discharge water to the north-west Bangladesh will be controlled by India.

The networking plan will have 14 links of the Himalayan components and another 14 links of the peninsular components. The Himalayan components are the Brahmaputra-Ganga (MSTG), Kosi-Ghagra, Gandak-Ganga, Ghagra-Yamuna, Sarda-Yamuna, Yamuna-Rajasthan, Rajasthan-Sabarmati, Chunar-Sone Barrage, Sone Dam-Southern Tributaries of the Ganges, Ganga-Damodar-Subarnarekha, Subarnarekha-Mahanadi, Kosi-Mechi, Farakka-Sundarbans, and Brahmaputra-Ganga (JTF)(ALT). The peninsular components are Mahanadi-Godavari, Godavari (Inchampali Low Dam)-Krishna (Nagarjunasagar Tail Pond), Godavari (Inchampali)-Krishna (Nagarjunasagar), Godavari (Polavaram)-Krishna (Vajayawada), Krishna (Almatti)-Pennar, Krishna (Srisailam)-Pennar, Krishna (Nagarjunasagar)-Pennar, Pennar-Chauvery, Chauvery-Vaigai-Gundar, Ken-Betwa, Prasbati-Kalisindh-Chambal, Par-Tapi-Narmada, Damanganga-Pinjal, Bedti-Varda, Netravati-Hemavati, and Pamba-Achankovil-Vaippar. 


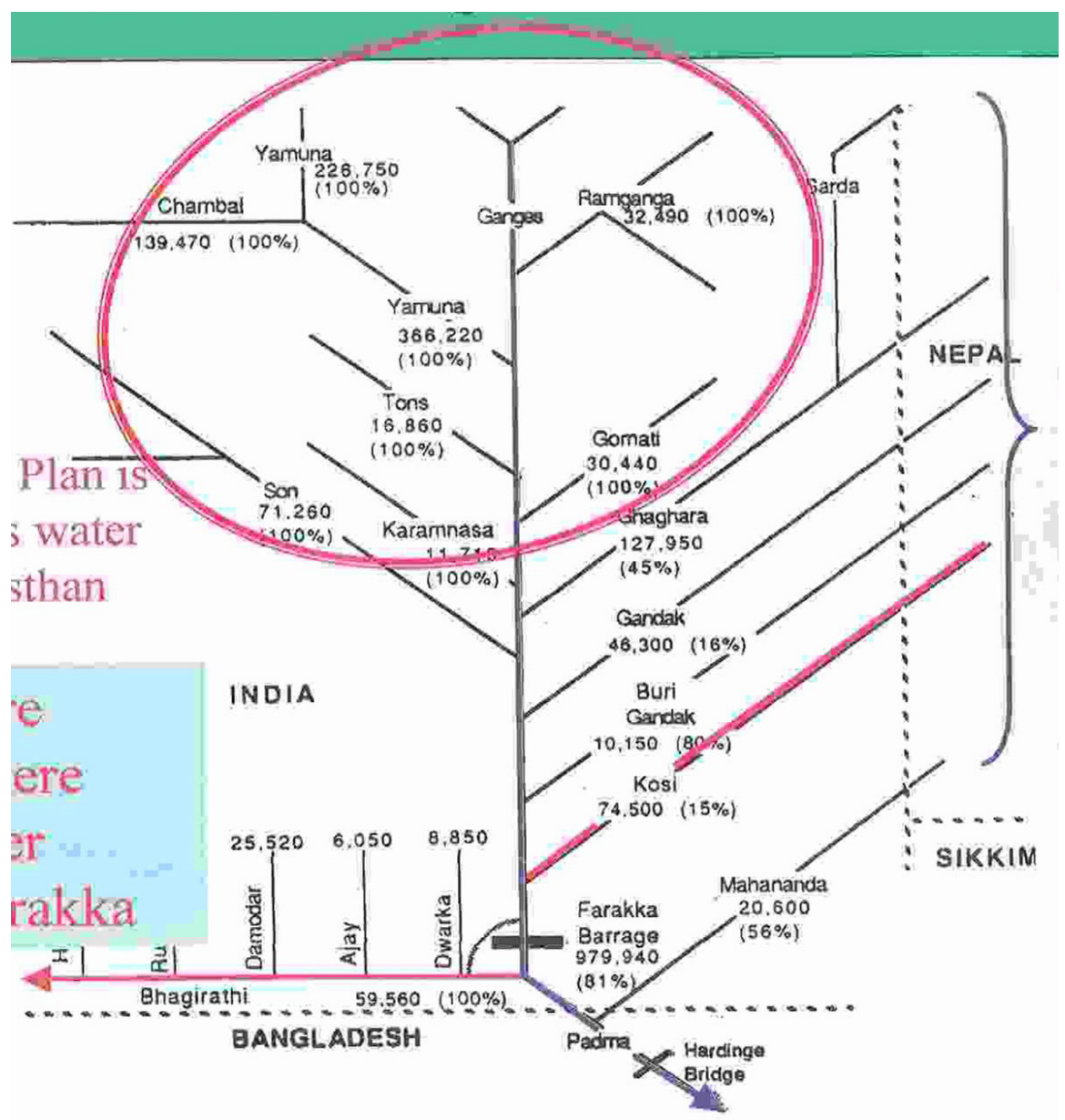

Figure 44. The Ganges basin catchment areas (Courtesy of Hossain et al., 2003).

As a result of the networking, the northern districts of Bangladesh will be deprived of the perennial river flows and will become dry, the Bangladesh Ganges will not have water past the Farakka point, the lean season flow of the lower Meghna will reduce substantially and the salinity front will be extended to the north. Further, the regional climate will change, and the arsenic contamination of groundwater will further aggravate.

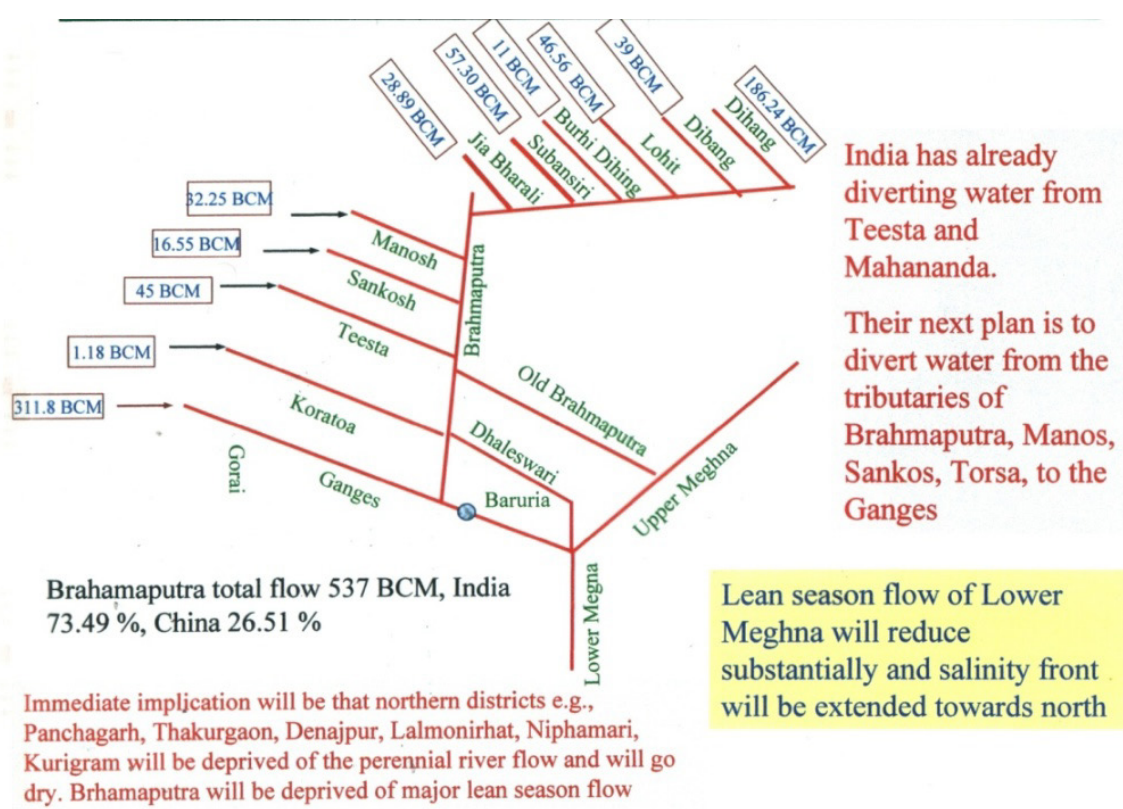

Figure 45. The Brahmaputra basin catchments (Courtesy of Hossain et al, 2003) 


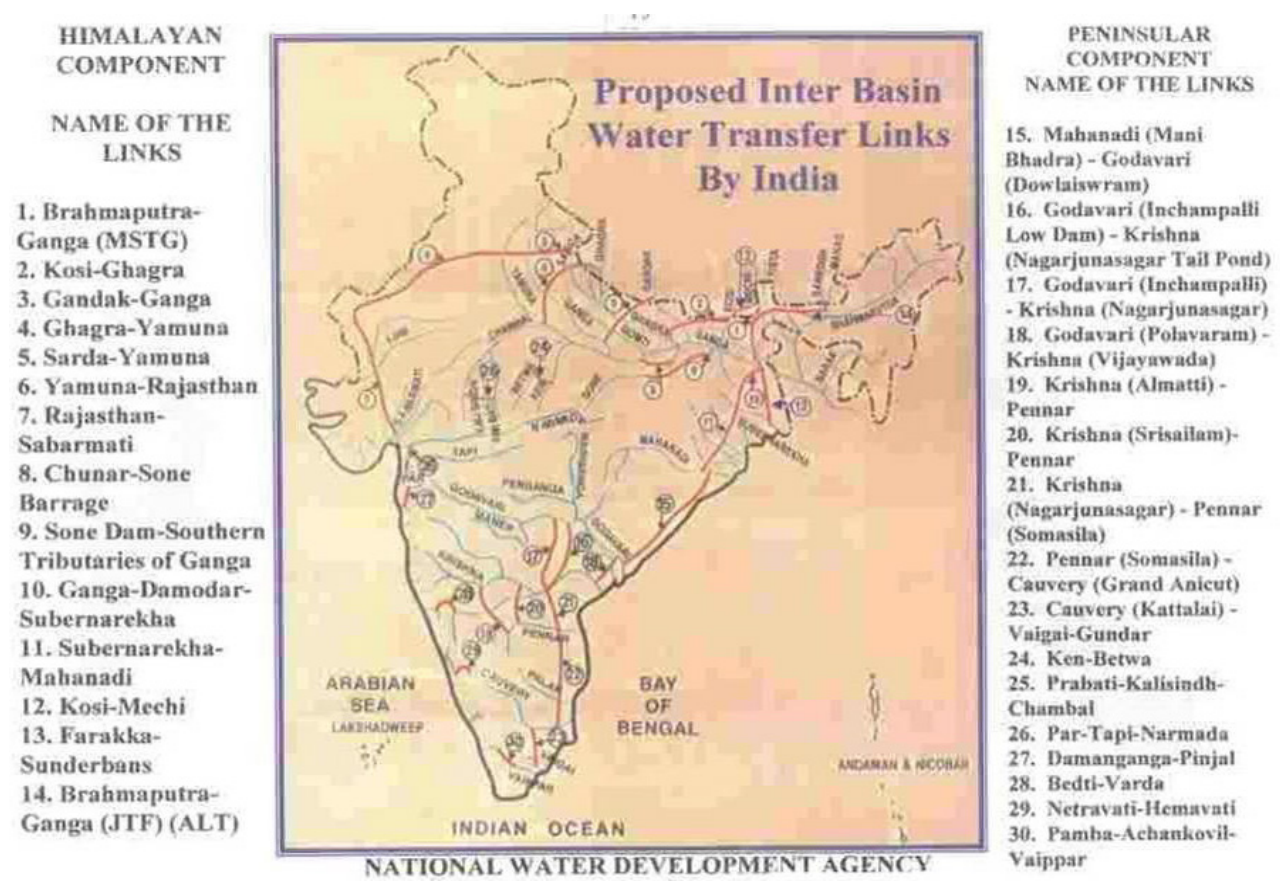

Figure 46. The grand river linking project of India

Table 6. Water Loss Figures

Mahanadi (Manibhadra)- Godavari (Dowlejwaram)
Godavari (Inchampallee-Kresna (Nagarjunsagar)
Godavari (Inchampallee)-Kresna (Pulisintalla)
Godavari (Polabharam)-Kresna (Bijoywada)
Kresna (Almati)-Pennar
Kresna (sreesailam)-Pennar
Kresna (Nagarjunsagar)-Pennar (Somasila)
Pennar (Somasila)-Kaveri (Grand Anicut)
Kaveri-Bhai-Gai-Gundar

$822 \times 10^{6}$ cubic meter
$376 \times 10^{6}$ cubic meter
$150 \times 10^{6}$ cubic meter
$150 \times 10^{6}$ cubic meter
$203 \times 10^{6}$ cubic meter
$215 \times 10^{6}$ cubic meter
$332 \times 10^{6}$ cubic meter
$385 \times 10^{6}$ cubic meter
$136 \times 10^{6}$ cubic meter

\subsection{Consequences Bangladesh Will Face}

Bangladesh will face similar consequences she faced in the Ganges basin, but on a much wider scale.

\subsubsection{Water Wasting in River Linking}

Millions of cubic meters of water will be wasted in the Indian Grand River linking plan. A partial list of some loss figures are given in table 6 . In some 9 out of 30 link canals, the loss is $2,768 \times 10^{6}$ cubic meter (Adel, 2013e, and the references therein).

\subsubsection{Impact Upon Bangladesh Ecosystem}

The grand plan will remove 200 to 250 billion cubic meters of water from the Bangladesh Brahmaputra, the Tista, and the Meghna basins. . Water bodies are heat retention bodies, too. The middle vales of the range will have a mass of about 225,000 billion $\mathrm{kg}$. For a variation of $1 \mathrm{oC}$ of temperature, this is a container and retainer of 225,000 trillion calories of heat. Both the summer and the winter will be extreme for the shortage of water. Bangladesh had the worst winter in 2013. Many morbities and fatalities were noted in the winter. Rainfall will decrease and will be irregular. People will lose their livelihoods. Natural diversity in the bio-world will be lost. Agricultural and industrial productions will fall. The basin will lose its internal immunity against natural calamities and will be a easy prey to climate change. The publicity of climate change is so strong that the basin will succum to this slogun and will forget the self-strength it will lose with the water resources.

As a result of the river linking, the situation in the Ganges basin will further worsen and the downstream of the Brahmaputra will face ecocide like that of the Ganges basin. The annual sediment carried by the Brahmaputra is 527 million tons. Due to the dwindling flow in the Brahmaputra, the sediment will be deposited in riverbeds and in sites of branching off of the distributaries in the reverse order of the tertiary, secondary, primary ones because of further slowing down of the river current for changes in direction in those sites. The canals, floodplains, and other surface water resources will be deprived of their annual water budget. The Old Brahmaputra and the Dhaleshwari are the primary and the Buriganga and the Shitollakhya are the secondary distributaries of the Brahmaputra. Decreasing river current will not have adequate aeration in water and the water's oxygen content will fall and the biological oxygen 
demand will increase and will be contaminated with choliform bacteria. The rising Brahmaputra bed will fail to receive water from its tributaries - the Teesta, the Dharla, the Korotoa, the Atrai, the Subarnasiri, the Hoorsagar, etc. etc. Losing the surface water bodies which are the natural wells for recharging groundwater, groundwater table will sink down and the fish resources will be gone inflicting people of malnutrition from essential minerals like calcium and animal proteins. People will be overly dependent on groundwater.

The coastal erosion will increase due to not having river discharge-carried sediment. The salinity front will make its way inland making the land infertile. There will be more water evaporating from the distributive sources than when water is localized. It may be mentioned that in normal irrigation process, the water loss from evaporation is 40 to 60 percent. There will be climatic changes as to rainfall, humidity, etc. which are subject matters of future research.

\subsection{GDP}

Bangladesh has been pushed in such a state where her GDP cannot be compared with that of other countries. No countries' permanent resources like land, water, and air are robbed by any other country in the world. But Bangladesh does. There being no changes in the permanent resources, the standard calculation of GDP does not include these permanent resources. It has been essential to redefine the GDP calculation if the GDP of a country that loses her permanent resources is to be compared with the GDP of other countries. GDP for Bangladesh is an invalid indicator of the country under Indian naked water aggression.

\subsection{Societal Issues}

Societal issues include making Bangladesh (i) a playground of Indian mafia, (ii) a business ground for drugs smuggled from India, (iii) frightened by killing of innocent Bangladeshi citizens by the Indian border terrorist force by falsely accusing them as criminals, (iv) suffer from a heavy trade imbalance with procrastination of removing it, (v) flooded with illegal arms smuggled from India, etc. etc. All these issues have surfaced truly in Bangladesh in spite of her continued courteous, friendly, and respectful dealing with India. Some instances of these unwanted activities are cited below.

As to the mafia activities, Indian nationals Rauf alias Daud Merchant, an associate of India Mafia Daud Ibrahim and his associate Mujahid were arrested in Bangladesh in May, 2009 (http://mediabangladesh.net/en/index.php?option=com cont ent\&view=article\&id=181:indian-mafia-boss-daud-mercha $\underline{\text { nt-arrested-in-bbaria-\&catid=16:politics-bangladesh-news \& }}$ Itemid=40).

At least 50 of the Daud mafia network personnel frequently visit Bangladesh. Indian government admits this mafia's network is spreading across South Asia and that the group is engaged in illegal economic activities like smuggling and drug running

http://www.thaindian.com/newsportal/world-news/indian -gangsters-expanding-dawood-ibrahim-network-in-banglad esh_100201460.html

Regarding the gruesome border killing of innocent civilians, Bangladesh's Home Minister Sahara Khatun reported in the Bangladesh Parliament of 151 innocent Bangladeshis killed by the Indian security forces as of the beginning of 2011. In spite of the Indian government's repeated assurances, these innocent people killings continues (http://archive.thedailystar.net/newDesign/news-details.php ?nid=240109). Words cannot describe these gruesome cases of killings. In the name of justice, India sets free the confessed accused criminal (Linkon, 2013). It seems Indian government tells one thing to the Bangladeshi counterpart and instructs the opposite to her security forces. Indian Border Security Forces (BSF) can better be termed Border Terrorist Forces (BTF) because of their inhuman actions.

Referring to WikiLeaks, News From Bangladesh reported on 29 October 2013, the killings of 57 army officers and inhuman torture to their women family members on 25 February 2009 was the result of the RAW's plan. The government invalidated the investigation report made by the army and prepared its own report. It was reported that shooters let in the Pilkhana area from India. The handling of the entire scenario by the government makes common people belief the government's prior knowledge of the massacre plan.

Indian drug smuggling to Bangladesh is very frightful for the nation. It is collapsing the society. Bulk of phensedyl bottles are smuggled through Tripura and Assam borders of India to Bangladesh (Fig. 47). In 2009, Bangladesh seized 58,875 phensedyl bottles and Indian border force 418,788 phensedyl bottles along the Bangladesh border. In 2010, India seized 3, 900 bottles of phensedyl that was entering Bangladesh from the Assam border. In 2011, Indian security forces seized phensedyl bottles worth of 1.050 million Indian currency (Das, 2012)

Trade imbalance is another darker side between the two countries. India is proud of being the world's $11^{\text {th }}$ largest economy and the $4^{\text {th }}$ largest in terms of purchasing power at the base of which stands her piracy of the $60 \%$ Ganges water from the downstream ecosystem.

(http://www.prep4civils.com/blog/daily-editorial/621/india $\% \mathrm{E} 2 \% 80 \% 99 \mathrm{~s}$-impetus-to-permanent-membership-of-secur ity-council/). She further claims to have provided leadership in the third world countries on many issues notably trade imbalances and environmental degradation whereas Bangladesh Bank and Export Promotion Bureau data show a galloping economic imbalance exists between India and her next door neighbor Bangladesh- $\$ 1,998.58$ million in fiscal 2006-07 reached $\$ 4,057$ million in 2010-11 (Fig. 48). About the environmental degradation by India to her neighbour, this article is enough. Indian policy is against responsibility-to-protect principle but for right-to-avail. 


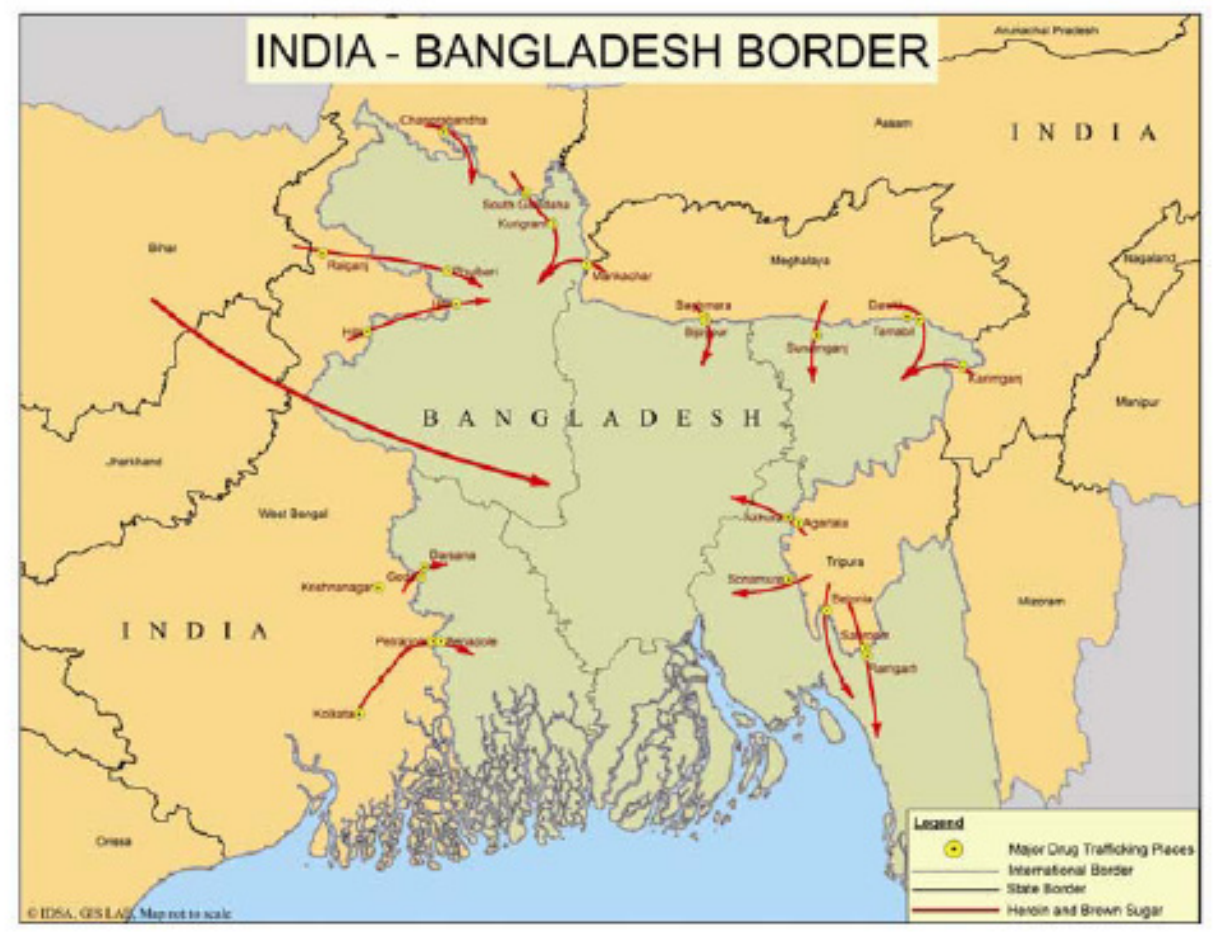

Figure 47. Drug smuggling routes to Bangladesh (http://www.idsa.in/system/files/OP_DrugTraffickinginIndia.pdf)

India grants high-interest loans to Bangladesh to dredge her clogged rivers whereas these rivers have been clogged by the Indian anthropogenic actions. It sounds like Indian water piracy constructions are an investment for India (Adel, 2012c).

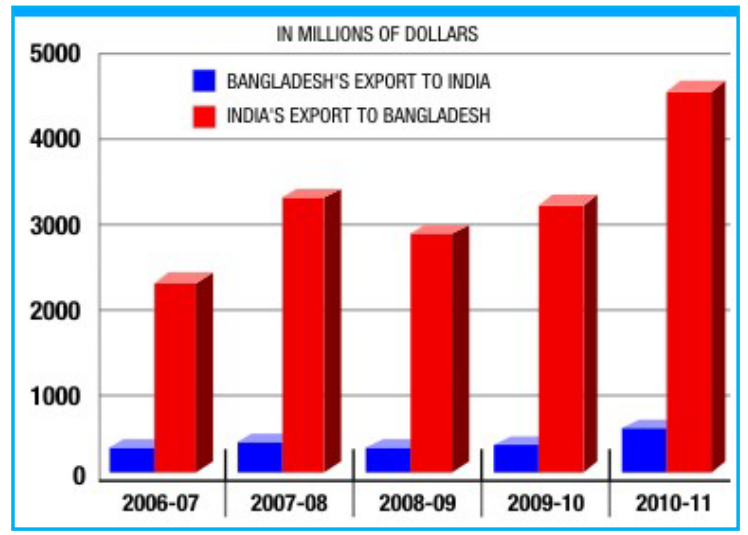

Figure 48. Bilateral trade gap between India and Bangladesh (ttp://www.thedailystar.net/newDesign/news-details.php?nid=201273).

Small firearms like pistols and revolvers are rampantly smuggled into Bangladesh through the three bordering districts of Chapainwababganj, Satkhira, and Jessore among which Jessore tops the list (Fig. 49). These are easy to carry and the professional criminals can buy the cheaply. In the period between January to July of 2013, police recovered 59 pistols and 19 revolvers. Their manufacturing places are Bihar and Calcutta in India (http://unbconnect.com/firearms-smuggling/\#\&panel1-6).

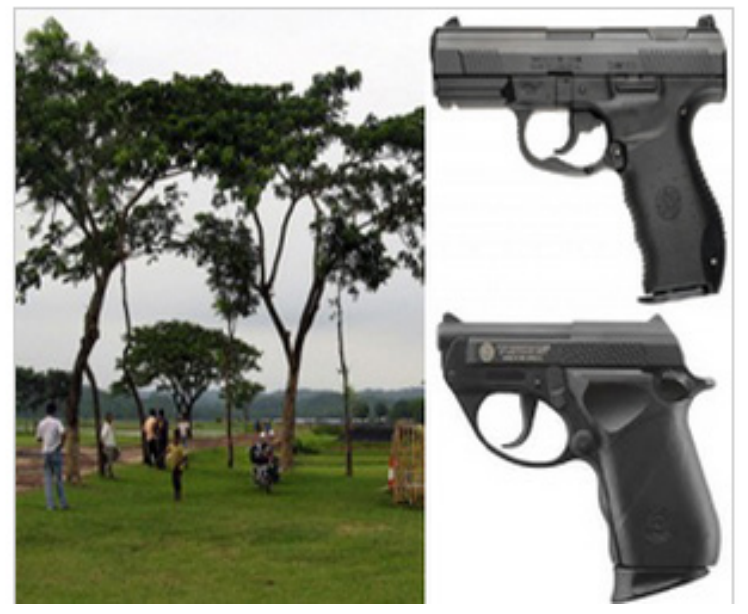

Figure 49. A typical scene of smuggling Indian firearms to Bangladesh.

\section{Discussions}

\subsection{Loss of Time and Wealth in the Marathon Number of Meetings}

The first job to kill a river is to obstruct the flow of its tributaries. India did the same thing. She locked the Hooghly's tributaries' and sub-tributaries' discharges in reservoirs and created a fake water shortage in the Hooghly, cornered Bangladesh over years by forcibly looting her ecosystem's water. So long Bangladesh had been clamoring, 
for her least survivability, to have some share of water. Actually, the Hooghly has more than a dozen of tributaries over almost the same length of course as the Bangladsh's Ganges which has only one tributary the Mahananda harnessed upstream by India for water diversion. India could have remained satisfied with the tributaries of the Hooghly. The huge amount of wealth wasted in marathon meetings could have been used for poor people of both the countries instead of harassing Bangladesh on the water issue. India's poor class is poorer than that of Bangladesh in hygienic and other conditions. This was stated even by the Nobel Laureate Amartya Sen. India has sky-rising hopes in capturing power and wealth and not in removing poverty and malnutrition of the Indian downtrodden class.

India favors a specific political party in power in Bangladesh through which India serves most of her interests. This is a blatant violation of human rights to corner a downstream riparian nation using the elixir weapon of water. India does not trust in "live and let live" in this era of saving the diversity.

\subsection{The Great Ring of Dams and Barrages}

There lies the ring of volcanoes around the coast of Japan and here lies the ring dams and barrages around the Bangladesh border. Nations coexist maintaining neighborly relations. In the history of anthropogenic activities, the construction of the ring of dams and barrages is unique. Dams and barrages have multiple effects which the lobbying authority keeps hidden. Volumes can be written on the effects. The abode of innumerable species has been depleted. Living beings are a component of the ecosystem. And is the elixir of the ecosystem. Robbing water of a country is an ecosystem crime. The upstream country, if fails to understand the gravity of the crime, international sanction should be put upon her in the interest of saving the humanity.

\subsection{Dams Favor River Bed Siltation}

When the discharge in the main river is drastically reduced, the origins of the distributaries become clogged depending on the bending angle of the discharge in the distributary from the main river, the current strength, and other features like narrowness, siltation, etc. Downstream velocity of water is overcome, at the origins of the distributaries because of the changing direction of the water current, by the gravity-driven settling speed for accumulation of silts. River discharges are carried from the primary distributaries to secondary and tertiary distributaries, and beyond, and then via canals to floodplains, ponds, ditches, and other low lands. The clogging effect is generally observed in the order of the remotest to the nearest of the main river in the absence of any local constraints. This has been the primary reason for the deaths of many distributaries and creation of floodplains in the downstream countries like Bangladesh.

\subsection{Water Piracy and not Water Diversion}

The upstream country's unaccounted amount of unilateral withdrawals has necessitated the use of the term "water piracy" which is due whenever an upstream country diverts water to such an extent as to harm the downstream ecosystem. India does this by pirating Ganges's downstream water for an unconnected river system, the Hooghly whose water remains stored in a number of reservoirs in the basins of its tributaries and sub-tributaries. Even forcing Bangladesh to authorize the piracy by signing the treaty, India does not follow the treaty. Additionally, she steals water from bordering rivers. Bangladesh is cornered for want of water if she does not authorize the piracy (Adel, 2012a). This is the conscience of a rising south Asian power.

Neighboring countries should not lose each other's trust, rather should gain it through actions. When Europe has formed EU and has been saving each other from economic hardships, an Indian sub-continental nation is subjected to crippling punishment by her neighbor. Subjecting Bangladesh to lesser and lesser quantity of water in successive temporary piracy treaties assures Bangladesh of requiring no water-sharing treaties in near future. It should be understood that assurance of adequate water availability for all riparian nations globally is as important as maintaining good air quality.

\subsection{Depletion of Aquatic the Habitat and Extinction of the Aquatics and the Resulting Mass Malnutrition}

In a riverine ecology, if the main supply river is obstructed in its discharge, it is easy to kill the distributaries that supply water to interior floodplain via canals. In the water budget, $76.5 \%$ comes from the Brahmaputra, the Ganges, and the Meghna, $22 \%$ if from rainfall, and $1.5 \%$ is from the groundwater which is on the verge of depletion because of the surface water shortage and overdependence on the groundwater. Deposition of silts over a few decades have clogged the origins of the distributaries and constricted them. As mentioned above, riverside fishermen's wives do not get water to take baths. Aquatics need the right amount of water at the right time of the season for sustained breeding. Also, the spawns need the right environment to survive. In a water-scarce land these are unthinkable. The depletion of surface water resources caused the extinction of the aquatics slowly if not abruptly. Fishes had been the only and the cheapest source of calcium, the bone-building element, and the only and the cheapest source of animal protein, one of the indispensables of life. With the depletion of the aquatics, the source for these nutrients is gone forever. Most of the people- young and old - complain of backache.

\subsection{Depletion of Inland Waterways}

Waterways are the cheapest means of transportation. Depletion of the surface water resources has made land transportation very crowded. Land transportation is costly 
and at the same time has become fatally accident-prone. Bangladesh pays in a multiple number of ways for looting its water resources by the upstream neighbor.

\subsection{Climatic Changes}

Water is the largest and most powerful reservoir for heat. Water reservoirs are heat reservoirs. Summer time water bodies absorb heat so that this heat cannot warm up the environment. Winter time the absorbed heat is released in the environment by the water bodies so that the environmental temperature cannot drop. The generation of unbearable heat and cold is just the absence of water bodies. People suffer many environmental diseases like asthma, hypertension, heart diseases, and in many cases several family members in the same family suffer from multiple diseases (Adel, 1999a).

Water begets water. Inland source of moisture is required for condensation of overland-coming moisture to cause rainfall. The scanty and erratic rainfall is because of the absence of the surface water bodies of the pre-piracy period.

\subsection{The Worst Made-made Disaster}

Arsenic minerals in the river basins remain inert under water. The sinking groundwater table has exposed the alluvium-buried arsenic mineral to air to have formed water soluble compounds of arsenic (Fig. 50). This water soluble compounds has infiltrated to groundwater.

$$
\begin{gathered}
\mathrm{FeS}_{2}(\mathrm{~s})+15 / 4 \mathrm{O}_{2}+7 / 2 \mathrm{H}_{2}=\mathrm{Fe}(\mathrm{OH})_{3}(\mathrm{~s})+4 \mathrm{H}^{+}+2 \mathrm{SO}_{4}^{2-} \\
\mathrm{As}_{2} \mathrm{~S}_{3}+8 \mathrm{O}_{2}+4 \mathrm{H}_{2} \mathrm{O}=2 \mathrm{HAsO}_{4}^{2-}+6 \mathrm{H}^{+}+3 \mathrm{SO}_{4}^{2-}
\end{gathered}
$$

Molecular oxygen oxidizes Fe (II) and S2 (-II0 to stable ferrihydrite $\mathrm{Fe}(\mathrm{OH})_{3}$ and dissolves sulfate $\mathrm{S}(\mathrm{VI})$ and $\mathrm{H}$ ions. In the acidic solution, the release of hydrogen and sulfate occurs to neutralize cations, and forms compounds of sulfate.

Arsenic is a poison. The USEPA and WHO recommend a dose of $10 \mathrm{ppb}$ ( $1 \mathrm{ppb}$ is about one drop in a large swimming pool of $70 \mathrm{cu}$ m of water). Even in the US standard, pregnant and/or breastfeedind mothers exhibit disruption in their lipid metabolism, leading to diminished nutrients in their blood and in their breast milk. Their offsprings showed significant deficiency in growth and development during their postnatal period before weaning (Drs. Hamilton and Koul-Horvath, Superfund Research Priogramm at Dartmouth, 2012). Bangladesh has set a standard of $50 \mathrm{ppb}$. In the case of the nutrient-fed US people what happened, has just been mentioned. It is unthinkable what can happen in the malnourished people of Bangladesh with this high dose. More than 75 million people are affected in Bangladesh. One in five deaths are linked to the drinking of arsenic contaminated water. A study of 12,000 Bangladeshis conducted by the director of the Center for Cancer Epidemiology and Prevention, Univ. of Chicago Medical Center

(http://www.uchospitals.edu/news/2012/20120223-arsenic-t oxicity.html).

\section{9. Salinity Intrustion and Coastal Erosion}

River discharges obstruct inland approach of the saline water front from the sea. Following the weak flows in the rivers, saline waterfront has advanced inland. Also, silt carried by the river discharges builds the coast which is always being eroded due to the impinging waves from the sea. While the Bangladesh coast has drastically lost the coast-building materials, sea waves have not stopped their coastal erosion.
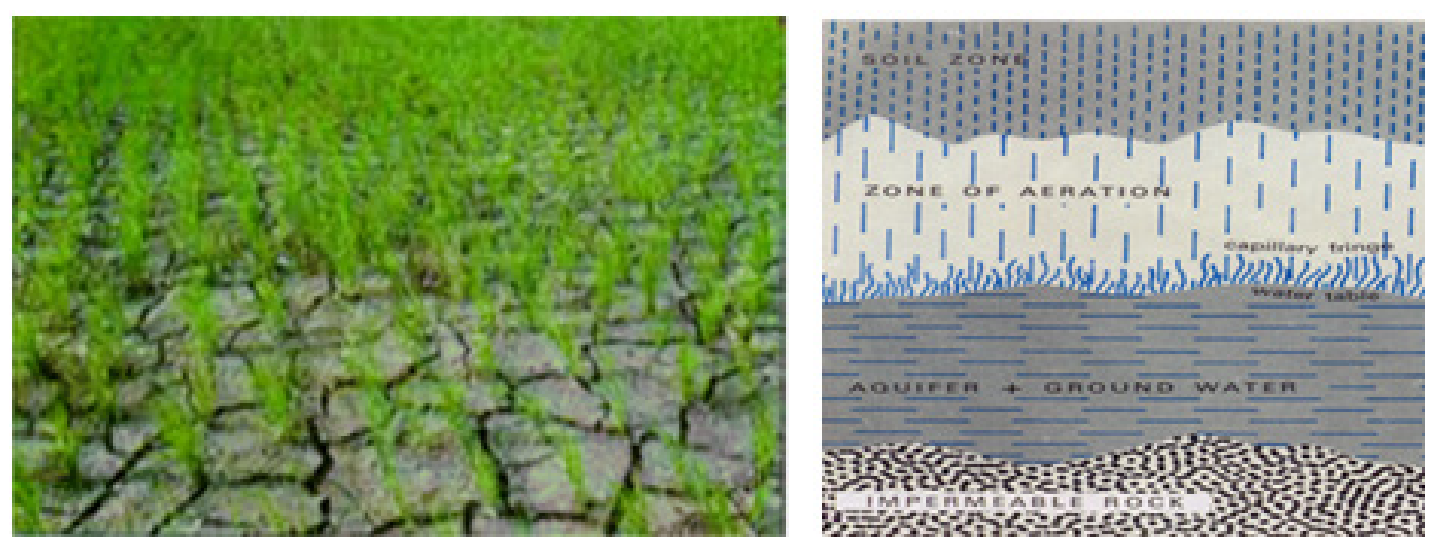

Figure 50. Aeration of alluvium-buried arsenic menerals (lfet) and groundwater infiltration (right) (Courtesy of the photograph and illustration providers) 


\subsection{GDP}

GDP is the market value of all finished goods and services within a country. Out of the three ways of determining GDP for Bangladesh in the presence of water piracy, the expenditure approach is the direct one because the labor cost and the irrechargable groundwater cost as well as other costs in the production of crops can be put together. However, the expenditure approach works on the principle that the total product must be equal to people's total expenditures. About $50 \%$ of the groundwater extracted evaporates in the air. The other $50 \%$ goes to the recharging. The one that goes intio the air cannot be got back because of irregularity and insufficiency of the monsson rainfall. This deficit in water builds up and ultimately leads to the depletion of the groundwater. Three economic health indicator indices are presented below. In the light of the natural resource depletion, GDP is an invalid indicator of economic health for Bangladesh.

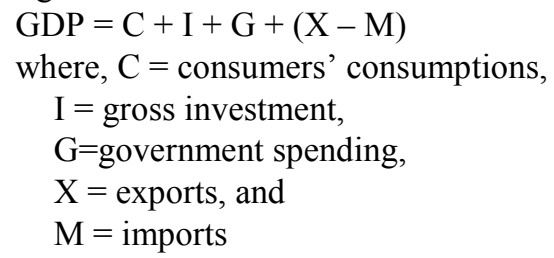

(http://en.wikipedia.org/wiki/Gross_domestic_product

No mentions of the loss or the deterioration of the country's permanent resouces is made in the formula

On the contrary, Genuine Progress Indicator (GPI) includes the deterioration of the natural resources.

$\mathrm{GPI}=\mathrm{A}+\mathrm{B}-\mathrm{C}-\mathrm{D}+\mathrm{I}$

where, $\mathrm{A}=$ income weighted private consumptions,

$\mathrm{B}=$ value of non-market services generating welfare,

$\mathrm{C}=$ private defensive cost of natural deterioration,

$\mathrm{D}=$ cost of deterioration of nature and natural resources, and

$\mathrm{I}=$ increase in capital stock and balance of international trade.

(http://en.wikipedia.org/wiki/Genuine progress indicator)

Else, the Index of Sustainable Welfare (ISEW) may be used to report the country's economic health. Roughly, its definition includes

ISEW $=$ personal consumption ++ public non-defensive expenditures - private defensive expenditures + capital formation + services from domestic labor - costs of environmental degradation - depreciation of natural capital (http://en.wikipedia.org/wiki/ISEW)

Some farmers raise small fishes along with rice cultivation in rice lands flooded with groundwater, the last resort of a nation. And some of the economists from abroad are considering this promising for the country and publishing articles after articles in the news media and journals (Ahmed et al., 2008; Ahmed and Luong-Van, 2009; Ahmed and Garnett, 2010, Ahmed et al., 2010, Ahmed et al., 2011). These economists gives the wrong information to the nation as well as to the outside world. This is not how sustainability is maintained in agricultural productions.

For efficient recharging, continuous rainfall is required. Once in a while, a sudden heavy rainfall does not yield favorable recharge. The infiltration rate in sandy soil is 1.2 inches per hour and it is the highest. In clay, this rate is less than 0.2 inch per hour (http://www.ehow.com/info_10025612_average-percolation -rate-various-soil-types.html). In other soil types, the infiltration rates lies in between these two limits. From the consideration of the infiltration rate, it should be clear how long time it takes under the favourable condition to recharge the groundwater.

Any political party in power is very desirous of showing increased growth in GDP. Since the GDP increase cannot be shown if the cost of water and its recharge is taken into account, the government does not talk about the issue of groundwater depletion. In the hope of earning some favor from the ruling party, no economists talk about the issue what the government does not like. A kind of degeneracy exists among the academicians who in the hope of gaining favors for administrative positions like the chairperson of a nation's leading bank become staunch supporters of the government.

\subsection{Border Killings, Drug and Firearms Smuggling, Mafia Intrusion, Pilkhana Massacre, and Trade Imbalance}

India never dared to kill a citizen when Bangladesh was East Pakistan. No border crossings by smugglers of drugs and firearms, mafia groups, army officer carnages happened during the days when Bangladesh had been East Pakistan. This is an Indian terrorising attitude to Bangladesh. India exploits the courtesy, friendship, respectfulness, gratefulness, and the sort of a small neighbor. When limits are reached, situation may backfire in some form.

India should realize that Bangladesh is a huge market for her. Indian market is spread over in marketing agricultural products, industrial products, technology, education, culture, medical treatments, tourism, etc. etc. Any slight Indian sacrifice that goes in favor of Bangladesh acts like an Indian investment in Bangladesh.

\subsection{River Linking Project}

The river linking plan will disrupt an equilibrium system naturally reached over hundreds or thousands years. The newly setup water-available system (call it A) and left-over water-available system (call it B). These two system will not be isolated from each other, and rather can be thought of interacting systems. A statistical thermodynamics model can be applied to these two interacting systems. The flow of energy between them will stop when a system is at the macrostate with the greatest multiplicity. Since these will be a continuously interacting systems, energy flow cannot stop (Schroeder, 2000). All it tells us that it can generage many different states involving 
heat, temperature, pressure, wind speed, rainfalls, etc.

\subsection{India's Violation of Ramsar Convention Pillars}

India is a member of the Ramsar Convention from the very beginning of 1971. This inter-governmental organization promotes to save wetlands irrespetive of its size, shape, type, temporal characteristics, origin, etc. through local, regional, and international cooperation. The member countries make contribution toward sustainable development throughout the world. The pillars of the convention are to make wise use of all wetlands, pay special attention to internationally important wetlands, stick to international cooperation. Because of her defiance of the pillars in practice and adoption of the opposite course of action as has been shown above, and her non-signatory status of the UN Convention on Law of Non-Navigational Uses of International Watercourses of 1977 and her reservations regarding its equitable and reasonable utilization and participation article 5 , India is a black stain on this great convention.

\subsection{International Committee on Irrigation and Drainage (ICID)}

New Delhi's this non-governmental organization is a farce on the face of what ecological disaster India has done in Bangladesh. It is misusing the word "international" for national interest. In the perspective of what has been said above, the organization should replace "International" by "National". The host of activities stipulated in the institutional agenda is as bluffing to the world as the Farakka Barrage to Bangladesh (Adel, 2013e).

\subsection{International Water Day Celebration}

India celebrates international water by crippling her neighbor through upstream water piracy. It would be better befitting if she use national water day celebration instead of calling it international and observing it in harmony with the world. She is the regional winner in the water game. She should duly call it national. International becomes a misnomer.

\section{Recommendation}

It is not only carbon emission in the air that causes the single event of global warming. We observe global warming as well as global cooling. Water is the single medium that can bring about both these effects. Former USSR dried up the Aral Sea in trying to be the world's number one cotton producer at the cost of causing climatic extremity and throat cancer epidemic to the Aral basin. India in drying up the Ganges through Bangladesh by water piracy has caused arsenic poisoning to the potable groundwater, brought about fatality-causing summer and wintertime extreme climate in the delta through depletion of heat-retaining surface water bodies, caused changes in river morphologies through sediment deposition and coastal erosion instead of building, etc. etc., to mention a few. Consideration of the fact that water is elixir and its absence causes wide spread multiple effects, and not a single one like addition of carbon in the air, water piracy crime should draw more attention than air pollution. International agencies like the UN should take steps to stop the crime of water piracy through international sanction. The body should stick to the definition of water piracy as the water management by the upstream country that causes damage of any degree to one or more components of downstream ecosystem. Under such international administration as proposed, riparian countries can maintain healthy ecosystem which is vitally important for climatic stability.

Also, land, air, and water are the permanent resources of a nation. The GDP of a nation stands on these capitals. Water piracy brings some anomaly in the comparison of GDP's of different nations. The GDP of a nation whose permanent resources are being looted by an upstream nation cannot be compared with that of the looter. The comparison will be that between apples and oranges. The UN should make an international law prohibiting piracy of any downstream country's permanent resource.

For environmental justice, India should compensate Bangladesh the astronomical losses she incurred in more than three and a half decades (Adel, 2013b) from her upstream water piracy and take immediate steps to return all the looted water resources to Bangladesh after bearing the establishment cost of all related infrastructures.

\section{Conclusion}

India has used the upstream water piracy from the Ganges and other common rivers between India and Bangladesh as a weapon for cornering Bangladesh who clamors for an agreement, for her least survival, and ultimately succumbs to India's mandated conditions. Due to Indian procrastination, both countries paid prices for meeting the largest number of times in the recorded history just for settling the Ganges water issue temporarily. The settlement lacks any arbitration that is likely to cause another cycle of marathon number of meetings at different levels between the two countries if the Ganges discharge is not exhausted within India due to piracy. The way dams and barrages have been planned at the upper reaches of the Ganges, the Ganges discharge is likely to exhaust within India leaving Bangladesh waterless in her Ganges basin. No upstream countries in the world have adopted the India policy of locking their own water to pirate water from one river system for the artificially-created water scarce basin in another river system. Future Bangladeshi generations will be at a worse level of stakes for the depletion of both surface and groundwater than the current stakes of surface water depletion, aquatics extinction, people's malnutrition, inland waterways disappearance, extreme climate generation, groundwater arsenic 
contamination, alarmingly sinking groundwater table, environmental diseases outbreak, inland salinity intrusion, coastal erosion, etc. etc. The picture of India and Bangladesh sounds like Aesop's fables of boys' pelting stones upon frogs in a marsh that kills the frogs and adds to the boys' rejoice. India should take lessons from the western nations who established and help. the Jewish state In the face of the downstream Bangladesh's ecocide effects and that water redistribution, too, makes climatic changes and that GDP is dependent on the stability of a country's land, air, and water resources, the UN should mediate international river water use by the riparian countries to make sure that not a single component of a downstream country's ecosystem is affected to any extent by the upstream country's water management. Violators should face international sanctions. India should set the environmental justice by compensating Bangladesh for the astronomical losses she has been causing.

\section{Acknowledgements}

Thanks are due to those whose illustrations and facts have made this article a reality.

\section{REFERENCES}

[1] Abbas, B. M., 1982. The Ganges Water Dispute, University Press Ltd., Dhaka, Bangladesh

[2] Adel, M. M. 1999a. The impact of climatic extremes and water shortage upon human health, World Resource Review, vol. 11, no. 4, pp. 576-601

[3] Adel, M. M. 1999b. Integrated investigation of the arsenic episode in Bangladesh, Indian Journal of Environmental Protection, vol. 19 , no. 9, pp. 652-660

[4] Adel, M. M. 2000a. Microlevel climate change in the Ganges basin", Journal of the Arkansas Academy of Sciences, vol. 53, pp. 83-91

[5] Adel, M. M. 2000b. Arsenic contamination in the groundwater of Biosphere III: causes and remediation", pp. 71-80, in H. Inyang and V. Ogunro, eds., Proceedings of the Fourth International Symposium on Environmental Geotechnology and Global Sustainable Development, Boston, MA

[6] Adel, M. M. 2001. Effects on downstream water resources from upstream water diversion in the Ganges basin”, Journal of Environmental Quality, vol. 30, pp. 356-368

[7] Adel, M. M. 2002. Man-made climatic changes in the Ganges basin, International Journal of Climatology, vol.22, pp.993-1016

[8] Adel, M. M. 2003. Biosphere III: The site of unprecedented ecocide in the Ganges basin pp. 59-79, in J. Ahmed, ed., National Documentation on the Problems of Arsenic and Farakka, published by the International Farakka Committee, Inc. , New York, NY
[9] Adel, M. M. 2004a. Impacts from trans-boundary water rights violations in South Asia, pp. 205-214, in R. Murray, K. Jacobson, and S. Anderson, eds., Proceedings of the 2004 Water Management Conference: Water Rights and Related Water Supply Issues, Salt Lake City, Utah

[10] Adel, M. M. 2004b. Upstream water diversion constructions on transboundary rivers, pp. 547-556, in R. Murray, K. Jacobson, and S. Anderson, eds., Proceedings of the 2004 Water Management Conference: Water Rights and Related Water Supply Issues, Salt Lake City, Utah

[11] Adel, M. M. 2005. Background state leading to arsenic accumulation in the Bengal basin Groundwater,, Journal of Water and Health, vol. 3, no. 4, pp.435-452.

[12] Adel, M. M. 2008a. International migration of Gangetic fishermen in South Asia, International Conference on Environment, Forced Migration \& Social Vulnerability, Bonn, Germany, 9-11 October, 2008. http://www.efmsv2008.org/files/International+Migration+of + Gangesfishermen + In + Souh + Asia + ?menu $=12$

[13] Adel, M. M and M. Husain, 2008. Sono filter waste disposals contradict safe environmental regulations, UNESCO-Sponsored International Conference on Water Scarcity, Global Changes and Groundwater Management Responses, University of California at Irvine, California, 15 December,

2008.http://www.groundwater.conference.uci.edu/files/chapt er1/2008_conf_AR

[14] Adel, M. M. 2008b. Natural river flow obstruction risks groundwater arsenic contamination, UNESCO-Sponsored International Conference on Water Scarcity, Global Changes and Groundwater Management Responses, University of California at Irvine, California, 1-5 December, 2008. http://www.groundwater.conference.uci.edu/files/chapter $1 / 2$ 008 conf AR

[15] Adel, M. M. 2008c. Ordeals to have due share of trans-boundary river water, UNESCO-Sponsored International Conference on Water Scarcity, Global Changes and Groundwater Management Responses, University of California at Irvine, California, 1-5 December, 2008 http://www.groundwater.conference.uci.edu/files/chapter $2 / 2$ 008_conf_AR

[16] Adel, M. M. 2012a. Downstream ecocide from upstream water piracy. Am. J. Environ. Sci., 8: 528-548.DOI: 10.3844/ajessp.2012.528.548, URL:

[17] Adel, M. M. 2012b. Ecosystems sustainability challenges from international river water plunderage, pp. 58-66. in S. $\mathrm{Rab}$ ed. Proceedings of the 3rd ABC Convention, Astoria World Manor, Astoria, Queens, NY, June 23-24, 2012.

[18] Adel, M. M. 2012c. Japadasyupana, Thikana , 24 February pp. 163-169.

[19] Adel, M. M. 2013a. Treeteo Jeebjagater ek Musa Khaner Kahinee(Story of the Musa Khan in the Bio-World III), Dibbo Prakash, 32/2 Khan Bangla Bazar, Dhaka 1100, Bangladesh ( in press)

[20] Adel, M. M. 2013b. Cunning Strategy for Upstream Water Piracy and Its Remedial Measures, Environmental Justice, Vol. 6, No. 4, 2013

[21] Adel, M. M. 2013c. Upstream water diversion contaminates downstream water", Environmental Justice Vol.6, No. 3, 
2013. Mary Ann Liebert, Inc. DOI: 10.1089/env.2013.0008

[22] Adel, M. M. 2013d. Farakka Barrage, the greatest ever riparian bluff for upstream water piracy, Academia Journal of Environmental Sciences 1(3):036-052, March 2013

[23] Adel, M. M. 2013e. Jaladasyupana, Dibbo Prakash, 32/2 Khan Bangla Bazar, Dhaka 1100, Bangladesh

[24] Adel, M. M. 2013f. Upstream water piracy impact upon the aquatic world and human dimension (in review in Horizon Publishing)

[25] Ahmed, N., Allison, E. H., Muir, J. F. 2010. Rice fields to prawn farms: a blue revolution in southwest Bangladesh? Aquacult. Int. 18:855-574.

[26] Ahmed, N., Garnett, S. T., 2010. Sustainability of freshwater prawn farming in rice fields in southwest Bangladesh. J. Sus. Ag. 34 (6), 659-679.

[27] Ahmed, N., Luong-Van, J., 2009. Can rice-fish farming provides food security in Bangladesh? Aquacul. Asia Mag. XIV (1), 18-23.

[28] Ahmed, N., Brown, J. H., Muir, J. F., 2008. Freshwater prawn farming in gher systems in southwest Bangladesh. Aquacul. Econ. Mgmt. 12 (3), 207-223.

[29] Ahmed, N., Zander, K. K., Garnett, S. T., 2011. Socioeconomic aspects of rice-fish farming in Bangladesh: opportunities, challenges and production efficiency. Austral. J. Ag. Res. Econ. 55, 199-219.

[30] Begum, K. , 1988. Tension over the Farakka Barrage, The University of Press Ltd., Dhaka, Bangladesh.

[31] Bindra, S. S., 1982, Indo-Bangladesh Relations, Deep and Deep Publications, New Delhi, India.

[32] Burns, J. F. New York Times, 1997, New York.

[33] Daily Dinkal, Thirty Years Water Treaty (in Bengali), December 15, 1996, Dhaka, Bangladesh

[34] Daily Janakantha, 1996., Thirty Years Water Treaty (in Bengali), December 13, Dhaka, Bangladesh

[35] Das, P., 2012, Drug Trafficking in India: A Case for Border Security, Institute of Defense Studies and Analyses, New Delhi, India

[36] Goodman, A. S., 1997. International Seminar on Farakka Barrage and Other Related Issues of Bangladesh (abs.). p. 10. In Shaheen et al., (ed.) A Publication of the International Farakka Committee for the International Seminar on Farakka Agreement, Arsenic Problem, Natural Gas, and Other Related National Issues of Bangladesh, September 28, New York.

[37] Haque, M. A., 2003. Bullying small ones/human rights violation in Bangladesh In: J. U Ahmad (ed.) National Documentation on the Problems of Arsenic and Farakka p. 99-104, Published by International Farakka Committee, Dhaka, Bangladesh

[38] Hebblethwaite, G. 1997. The impacts and implications of the Farakka Barrage upon Bangladesh. B. S. Thesis, University of New Castle Upon Tyne, UK.

[39] Hillary, E. S., 1979, From Ocean to the Sky, p. 35. Viking Publisher, New York.
[40] Husain, M. T., E. R. Morrison, T. E. Bridge, L. J. Berryhill, Md. R. Islam, M. Uz-Zaman. M. Alam, M, M. Adel, and T. Stovak. 2010, Freedom Water Filter System: a Solution to the Arsenic and Pathogen contaminated Water Crisis in Bangladesh \& Other Underdeveloped Nations., 4th International Conference on Water Resources and Arid Environments (ICWRAE 4):184-213, http://www.icwrae-psipw.org/images/stories/2010/Wate_Res ources/21/index.html International Journal of Water Resources \& Arid Environments (2010)5-8 December 2010, Saudi Arabia.

[41] Linkon, A., 2013. Felona noy Felanir ranka o jeeban (Not to throw away Felani's blood and life), Thikana, vol. 24, no. 30, September 06, 2013.

[42] Miah, M. A. 1995. Integrated effects of water diversion, pp. 23-24, in FOBANA Conveners eds., Proceedings of 8th Annual Convention of the Federation of Bangladeshi Associations of North America (FOBANA), Montreal, Canada

[43] Miah, M. A. 1996a. The water crisis in Bangladesh: a challenge to integrated water management in urban areas, Environmental Research Forum, vol. 3-4, pp. 69-86

[44] Miah. M. A. 1996b. Ecocide in the Ganges basin, The Message, pp. 13-14, May 1996

[45] Miah, M. A. and M. A. Samad, 1996. History of the environment of Bangladesh, pp. 214-227, in W. Schroder and W. Calocino, eds., Global Change and History of Geophysics, Bremen- Roennebeck, Germany

[46] Miah, M. A. 1996b. Farakka Barrage: an unprecedented environmental disaster in the Ganges basin, pp. 18-31, in T. S. Rehman, ed., Perspectives of the Thirty-Year Water-Sharing Treaty, Bangla Bazar Publisher, Dhaka, Bangladesh

[47] Miah, M. A. 1996c. Signs of climatic changes in Ganges basin, Bitchitra, (in Bengali) vol. 10, pp. 14-21

[48] Miah, M. A. 1997. Biosphere III and the destructive activities of river barrages, Bitchitra, vol. 22, pp. 25-31.

[49] Sattar, M. A., 1997. Farakka: Bangladesher Bhagya Zekhane Bondi, Padma Prakashani, Dhaka, Bangladesh

[50] Sattar, M. A., 1998. Bangladesh-Bharat Ovinno Nodir Pani Sankot (Bangladesh-India Transboundary River Crisis), Tofazzel Hossain Vishwya Sahitya Bhaban, Banglabajar, Dhaka, Bangladesh.

[51] Schroeder, D. V., 2000. An Introduction to Thermal Physics, Addison Wesley Longman, New York, pp.49-67

[52] Sufian, A. K., 1993. Farakka Barrage - An Overview, in Proceedings of the International Seminar on Farakka Barrage, Forakka Committee (ed.), October 10. Columbia University, New York, pp. 25-26.

[53] Prakash, A. 1998. Farakka Barrage Causes Concern."THIRD WORLD NETWORK FEATURES” oibs@bom2.vsnl.net.in.

[54] Subramaniam, K. S., and M. J. Kosnett. 1998. Human exposure to arsenic from consumption of well water in West Bengal, India. International Journal of Occupational \& Environmental health 4:217-230.

[55] Winter, T. C., W. Harvey, O. L. Fanke, and W. M. Alley, W. 
M. 1998. Groundwater and Surface Water a Single Resource. U. S. Geological Survey Circular 1139, Denver, Colorado

[56] Zaman, Q., 2012. Personal communication

[57] (http://users.physics.harvard.edu/ wilson/arsenic/pictures/ars enic_project_pictures2.html)

[58] http://en.wikipedia.org/wiki/Damodar_River

[59] (http://www.nvo.com/ghosh_research/nss-folder/pictures/W b_map_new.jpg). http://users.physics.harvard.edu/ wilson/arsenic/pictures/ars enic_project_pictures 2 .html

[60] (http://www.nvo.com/ghosh_research/nss-folder/pictures/W b_map_new.jpg). http://users.physics.harvard.edu/ wilson/arsenic/pictures/ars enic_project_pictures $2 . \mathrm{html}$

[61] (http://www.slideshare.net/Manushilndia/ganga-held-captive

[62] (http://www.soesju.org/arsenic/arsenicContents.htm?f=alb 4 7.html).

[63] (http://www.trust.org/alertnet/news/water-shortages-threaten -renewed-conflict-between-pakistan-india/).

[64] (http://www.waterinfo.net.pk/pdf/mbp.pdf).

[65] http://www.dawn.com/2004/04/13/local12.htm). 